Cláudia Jeane Claudino de Pontes Miranda

\title{
Avaliação da função e da histopatologia pulmonar em modelo experimental de inflamação pulmonar alérgica crônica: efeitos da redução da função colinérgica em camundongos geneticamente modificados
}

Dissertação apresentada à Faculdade de Medicina da Universidade de São Paulo para obtenção do título de Mestre em Ciências

Programa de Ciências Médicas

Área de Concentração: Processos Inflamatórios e Alérgicos

Orientadora: Profa. Dra. Carla Máximo Prado

São Paulo

2012 
Dados Internacionais de Catalogação na Publicação (CIP)

Preparada pela Biblioteca da

Faculdade de Medicina da Universidade de São Paulo

Creprodução autorizada pelo autor

Miranda, Cláudia Jeane Claudino de Pontes

Avaliação da função e da histopatologia pulmonar em modelo experimental de inflamação pulmonar alérgica crônica : efeitos da redução da função colinérgica em camundongos geneticamente modificados / Cláudia Jeane Claudino de Pontes Miranda. -- São Paulo, 2012.

Dissertação(mestrado)--Faculdade de Medicina da Universidade de São Paulo. Programa de Ciências Médicas. Área de Concentração: Processos Inflamatórios e Alérgicos.

Orientadora: Carla Máximo Prado.

Descritores: 1.Proteína de transporte vesicular de acetilcolina 2.Asma brônquica 3.Acetilcolina 4.Inflamação experimental dos pulmões 5.Mediadores da inflamação

USP/FM/DBD-122/12 


\section{Dedicatória}

A Deus.

Aos meus pais, meu eterno amor e agradecimento, estudar sempre foi prioridade em nossa casa, fui criada com rigor e muita responsabilidade. Aquilo que parecia exagero na adolescência logo fez todo sentido. Obrigada por me incentivar em todos os momentos e mostrar que o mundo nem sempre é colorido.

Ao meu marido, Rogério Miranda, homem de caráter impecável, pai exemplar, obrigada pela paciência, sei que não é fácil estar casado com uma mestranda em período de qualificação e defesa. Ficamos focados e alguma vezes distantes, mas casamento também é parceria nos sonhos. Agradeço pelo eixo de equilíbrio que você é em minha vida e pelo nosso amor que faz meus dias mais felizes.

A lasmin e ao Rogério, meus amados filhos, a razão e o porque de tudo, bálsamos dos meus dias de cansaço, encontra-los no santuário (nossa casa), ao voltar de um dia intenso de trabalho e abraça-los com aquele sorriso recíproco que sempre me espera, faz todos os dias valer a pena e dar cor a minha vida. Obrigada por me fazer sentir este amor abnegado, puro que me enche de alegria e pela confiança de que agora minha jornada nesta vida será sempre de mãos dadas. A vocês meus filhos todo o meu amor.

A Luciana Ritha de Cássia Rolim Barbosa Aristóteles, minha grande amiga, mulher honesta e inteligente, companheira de todas as horas, aquela que sabe de mim com um olhar, seu humor inteligente e irreverente alivia todas as tempestades. Nossa vida vem caminhando junto na alegria e na tristeza e sempre uma equilibrando a outra. Obrigada por simplesmente me dar a essência do teu jeito de amar que é único e muito especial.

A equipe de fisioterapeutas, médicos e enfermeiros do Hospital Alemão Oswaldo Cruz, 15 anos de parceria, aprendi muito com vocês amigos, era uma 
menina quando cheguei, amadurecemos juntos, rimos e choramos. Obrigada por fazerem parte do meu crescimento pessoal e profissional.

A todos os professores que passaram na minha vida, desde a mais tenra infância, não estaria exatamente onde sonhei estar se não fosse o incentivo de vocês. Lembro do rosto de cada um e da alegria em ensinar. Meu respeito e minha profunda admiração pelo seu trabalho. 


\section{Agradecimentos}

Tirar leite de pedra é a especialidade dela, entre tantas, adora desafios, o VAChT a partir dela começou a ser gerado na USP, flex-vent com problemas...escuto passos fortes e uma voz firme... vamos resolver isto já...grupo experimental todo perdido...animais com ascite intensa...alunos surtados...resultados do sigma plot conflitantes. O telefone toca, sempre estar online ou presente, voz austera ao incentivar, mas sem perder a doçura, mãos firmes nos experimentos...passamos os resultados as 23:50 do laboratório por telefone ...ela sorrir e comemora. Ela...é minha orientadora Carla Máximo Prado, mulher de caráter marcante, personalidade forte, ética e inteligente...aquela que me resgatou da saudade que eu tinha de mim. Obrigada por simplesmente você ser assim integra, humana e transparente e principalmente pelos anos de convivência envoltos de muito aprendizado e incentivo. Sem você este sonho não seria possível...não há como the agradecer. Seu sobrenome lhe faz Jus.

A Nathália Pinheiro Montoro, companheira inseparável dos experimentos, leituras de lâminas, protocolos de sensibilização, transporte dos VAChTs. Vi esta menina chegando no laboratório, gravem bem o nome dela, será uma grande pesquisadora. Presença firme, exemplo de ética e competência e orgulhosamente é minha amiga. Obrigada por sua mão firme, presença agradável e principalmente pelas noites no laboratório que foram responsáveis pela força desta amizade, carinho e admiração que tenho por você.

A Ana Beatriz Montanheiro, companheira dos experimentos, sua característica marcante é a inteligência e organização. Muito obrigada pelo papos terapêuticos e por toda ajuda durante a realização deste projeto. 
A $\operatorname{Dr}_{\mathrm{a}}$ Adenir, presença marcante, silêncio total, tudo preparado para recebêla, experimento organizado, mãos habilidosas e incomparáveis. Meus mais sinceros agradecimentos.

Agradeço a fundação de amparo à pesquisa do Estado de São Paulo (FABESP) pelo o apoio financeiro a realização deste projeto. 
Há um tempo em que é preciso abandonar as roupas usadas, que já tem a forma do nosso corpo, e esquecer os nossos caminhos, que nos levam sempre aos mesmos lugares. É o tempo da travessia: e, se não ousarmos fazê-la, teremos ficado, para sempre, à margem de nós mesmos Fernando Pessoa. 
Esta dissertação está de acordo com as seguintes normas, em vigor no momento desta publicação:

Referências: adaptado de International Commitee of Medical Journals Editors (Vancouver)

Universidade de São Paulo. Faculdade de Medicina. Divisão de Biblioteca e Documentação. Guia de apresentação de dissertações, teses e monografias. Elaborado por Anneliese Carneiro da Cunha, Maria Julia de A. L. Freddi, Maria F. Crestana, Marinalva de Souza Aragão, Suely Campos Cardoso, Valéria Vilhena. 3ª̣ed. São Paulo: Divisão de Biblioteca e Documentação; 2011.

Abreviatura dos títulos e periódicos de acordo com List of Journals Indexed in Index Médicus. 
SUMARIO 


\section{SUMÁRIO}

Lista de Abreviaturas e siglas

Lista de Figuras e Tabelas

Resumo

Summary

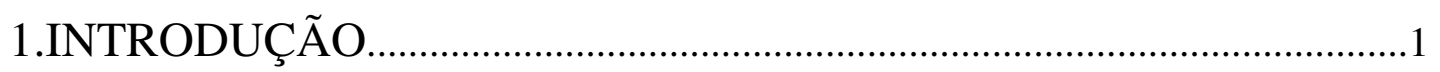

1.1 Asma Brônquica....................................................................

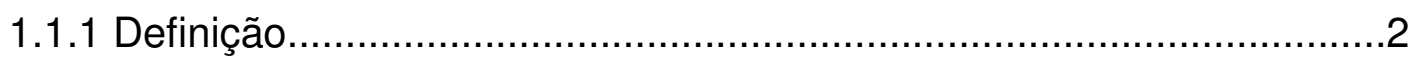

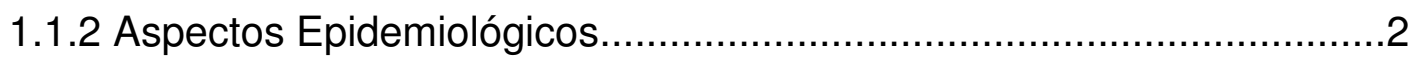

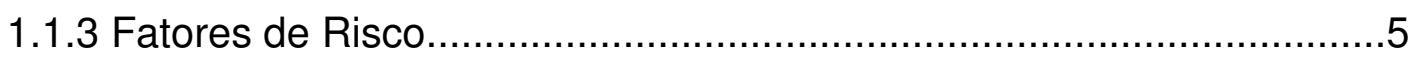

1.1.4 Fisiopatologia da Asma.....................................................

1.1.4.1 Inflamação e Mediadores Envolvidos na Asma..............................13

1.2 Acetilcolina e Pulmão...............................................................18

1.2.1 Receptores Muscarínicos....................................................21

1.2.2 Sistema Colinérgico Antiinflamatório e Receptores Nicotínicos.........24

1.3 Modelo de Asma Experimental...............................................32

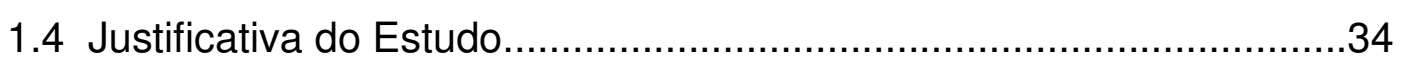

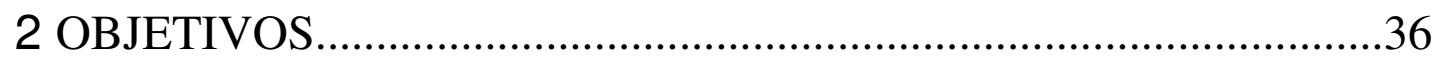

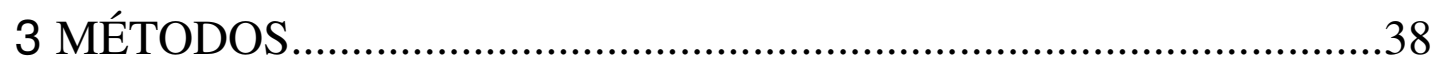

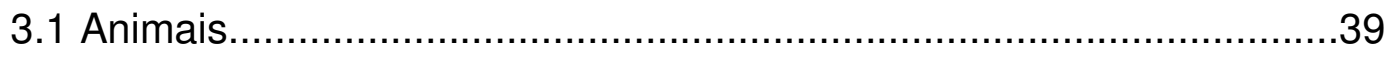

3.2 Grupos Experimentais..........................................................40

3.3 Indução da Inflamação Pulmonar Alérgica Crônica...........................40

3.4 Avaliação da Mecânica do Sistema Respiratório..............................42

3.5 Lavado Bronco Alveolar......................................................44

3.6 Estudo Morfométrico..................................................................45

3.6.1 Avaliação do Edema Peribrônquico e Células Inflamatórias ao Redor das Vias aéreas....................................................................... 45

3.6.2 Avaliação do Remodelamento Brônquico.....................................46

3.6.3 Imunohistoquímica para Detecção de Celulas Positivas para IL-4, 


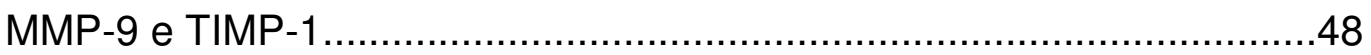

3.7 Análise das Citocinas no Homogenato Pulmonar...........................48

3.8 Analise Estatística............................................................49

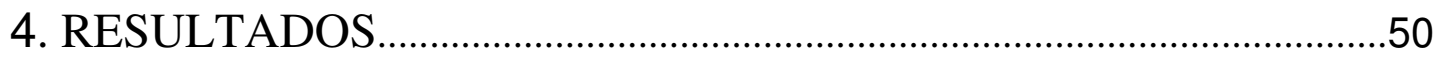

4.1 Avaliação da Mecânica Respiratória...........................................51

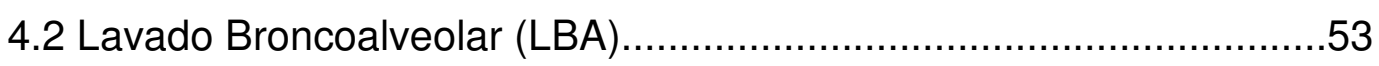

4.3 Avaliação do Edema Peribrônquico................................................55

4.4 Células Inflamatórias Peribrônquicas............................................55

4.5 Remodelamento de Vias Aéreas......................................................58

4.6 Citocinas no Pulmão....................................................................60

4.7 Expressão de MMP-9 e TIMP-1 em Células Inflamatórias.................61

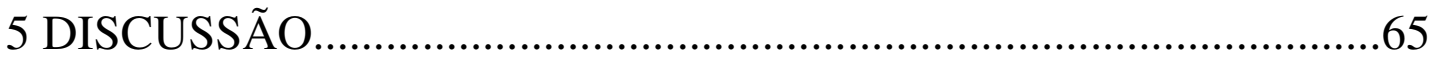

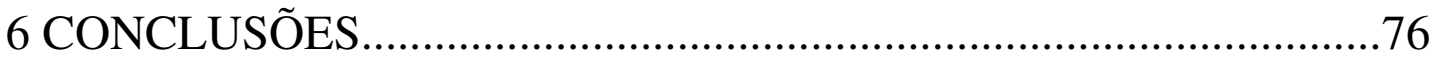

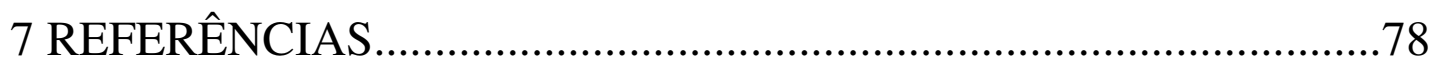




\section{LISTA DE FIGURAS E TABELAS}

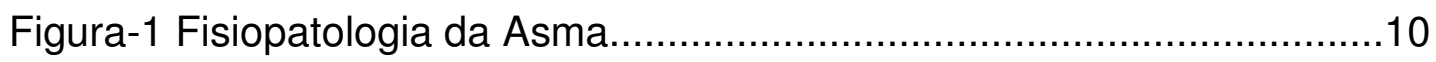

Figura-2 Sintese de Acetilcolina..............................................................19

Figura-3 Inervação Parassimpática dos Pulmões.........................................21

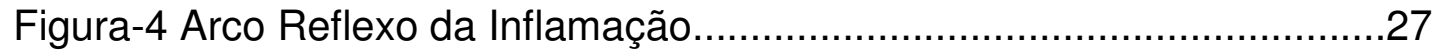

Figura-5 Mecanismos Colinérgicos Antiinflamatório ………...........................31

Figura-6 Esquema do Protocolo de Sensibilização........................................41

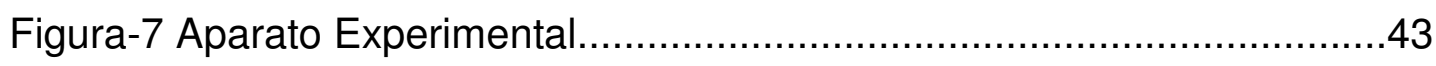

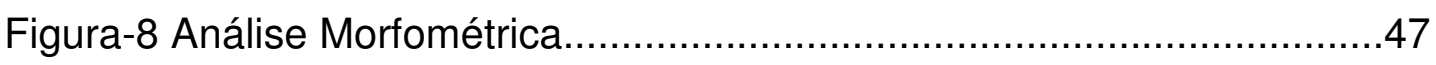

Figura-9 Avaliação da Mecânica Pulmonar...............................................52

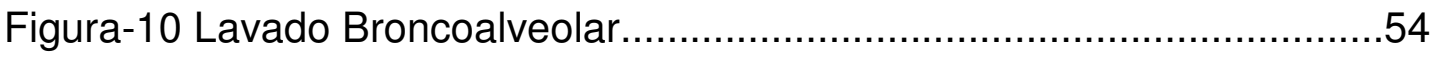

Figura-11 Avaliação de Edema Peribrônquico...........................................56

Figura-12 Células Inflamatórias Peribrônquicas...........................................57

Figura-13 Remodelamento de Vias Aéreas.............................................59

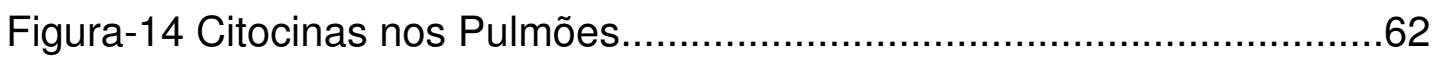

Figura-15 Expressão de MMP-9 e TIMP-1 em Células Inflamatórias............63

Figura-16 Fotomicrografia do Pulmão do Animal........................................64

Tabela-1 Fatores de Risco para a Asma.....................................................

Tabela-2 Principais Citocinas na Asma........................................................17

Tabela-3 Receptores nicotínico no Pulmão................................................28 


\section{LISTA DE ABREVIATURAS E CICLAS}

ACh: Acetilcolina

CD14 e TLR4: Proteínas de Ligação

ChAT: Acetiltransferase

CHT1: Transportador de Colina de Alta Afinidade

Datasus: Base de dados do Sistema Único de Saúde

DPOC: Doença Pulmonar Obstrutiva Crônicas

ECP: Proteina Catiônica Eosinófilica

FcعRIß: Receptor de lgE de Alta Afinidade

Gina: Iniciativa Global para a Asma

GM-CSF: Fator Estimulador de Colônias de Granulócitos-Macrófagos

HMGB1: Proteína do Grupo de Alta Mobilidade

HOMO: Animais com Deficiência Colinérgicai

ICAM-1: Moléculas de Adesão Intracelular -1

IFN-Y: Interferon

IgE: Imunoglobulina

IL: Interleucina

LBA: Lavado Bronco Alveolar

LISTA DE ABREVIATURAS

LPS: Lipopolissacarídeos

M1-M5: Receptores Muscarinicos

M2AChR: Receptor Muscarinico do Tipo 2

M3AChR: Receptor Muscarinico do Tipo 3

MBP: Proteina Básica Principal

MEC: Matriz Extra-Celular

MHC II: Complexo Principal de Histocompatibilidade de classe II MIP: Proteina Inflamatória do Macrófago 
MMP: Metaloproteinases

MN: Mononucleares

nAChRs: Receptores nicotínicos

NF-kB: Fator Transcricional

OMS: Organização Mundial de Saúde

OVA: Ovoalbumina

PAF: Fator de Ativação das Plaquetas

Pao: Pressão de Abertura das Vias Aéreas

PBS: Tampão Fosfato Salina

Pcyl: Pressão do Cilindro do Flex-Vent

PMN: Polimorfonucleares

Ptr: Pressão Traqueal

RFO::Espécies Reativas de Oxigênio

SAL: Animais do Grupo Salina

SOCS3: Proteína Antiinflamatória

STAT3: Fator de Transcrição

T: Tempo

TCD4: Linfócitos TCD4

TGF- $\beta$ : Fator Transformador de Crescimento Beta

TIMP: Inibidores Teciduais

TNF-a: Fator de Necrose Tumoral

V: Volume

$V^{\prime}$ : Fluxo

VAChT: Proteína Transportadora Vesicular de Acetilcolina

VCAM-1: Moléculas de Adesão Vascular 1

Vcyl: Volume de Corrreção Indireto Pela Quantidade Fornecida

WT: Animais Selvagem sem Modificação Genética 
a7nAChR: Receptor nicotínico $\alpha 7$ para Acetilcolina

\%Ers: Porcentagem de Elastância

\%Rrs: Porcentagem de Resistência 
RESUMO 
Miranda CJCP. Avaliação da função e da histopatologia pulmonar em modelo experimental de inflamação pulmonar alérgica crônica: efeitos da redução da função colinérgica em camundongos geneticamente modificados [Dissertação]. São Paulo: Faculdade de Medicina, Universidade de São Paulo; 2012.

INTRODUÇÃO: A Asma Brônquica é caracterizada por obstrução ao fluxo aéreo, reversível ou não, e processo inflamatório pulmonar, caracterizado principalmente por eosinofilia. A persistência da inflamação pode induzir processo de reparo pulmonar associado à redução progressiva da função pulmonar. A recente descrição do sistema colinérgico anti-inflamatório, um mecanismo neural que suprime a resposta imune inata e controla a inflamação por inibição de citocinas proinflammatórias, e a detecção de alguns de seus componentes em células de vias aéreas sugerem uma importante participação deste sistema na fisiopatologia de doenças pulmonares. O principal mediador deste sistema é a acetilcolina (ACh), que é estocada em vesículas sinápticas pelo transportador vesicular de ACh (VAChT), proteína essencial para sua liberação. OBJETIVOS: Avaliar os efeitos da deficiência colinérgica por redução da VAChT nas alterações pulmonares observadas em modelo experimental de inflamação pulmonar induzida pela exposição crônica a ovoalbumina. METODOLOGIA: A redução colinérgica foi induzida pela modificação genética nos níveis de VAChT. Camundongos machos selvagens e mutantes foram submetidos ao protocolo de sensibilização subcutânea com ovoalbumina ou salina nos dias 0,7 e 14 . Após, foram submetidos a desafios inalatórios com ovalbumina a $1 \%$ ou inalações de salina por 20 minutos nos dias 26, 27 e 28. No dia 29, foi realizada a avaliação da mecânica pulmonar, da inflamação no lavado broncoalveolar e no tecido e análise histológica de remodelamento e expressão de MMP-9 e TIMP-1 por imunohistoquímica. Também foi quantificado por ELISA níveis de IL-4, IL-10 e de TNF- $\alpha$ no homogenato pulmonar. A análise estatística considerou um $p<0,05$ como significativo. RESULTADOS: Animais sensibilizados apresentaram hyperresponsividade brônquica, inflamação e edema peribrônquico e deposição de fibras colágenas e elásticas ao redor das vias aéreas comparado ao grupo salina $(p<0,05)$. Além disso houve aumento de IL-4 no homogenato pulmonar e da expressão de MMP-9 e TIMP-1 nas células inflamatórias. Os animais mutantes, independente de serem ou não sensibilizados, apresentaram aumento de TNF- $\alpha$ no pulmão. Os animais mutantes que foram submetidos ao protocolo de sensibilização mostraram aumento da hiperresponsividade brônquica, do eosinófilos, do edema e da deposição de colágeno comparado aos animais selvagens que também foram sensibilizados com ovoalbumina. Estas alterações podem ser atribuídas ao aumento de IL-4 e de MMP-9/TIMP-1 que foi observado nos animais mutantes e sensibilizada em comparação com o os selvagens sensibilizados. Não houve diferença nos níveis de IL-10 nos grupos experimentais. Conclusão: A deficiência colinérgica piora a hiperresponsividade brônquica, a inflamação eosinofílica e o remodelamento, principalmente por interferir com a citocina pró-inflamatória IL-4 e na proporção de MMP-9 e TIMP-1. Estes dados sugerem que a via colinérgica antiinflamatória está envolvida na fisiopatogenia da asma e necessita ser mais investigada.

DESCRITORES: proteína de transporte vesicular de acetilcolina, asma brônquica, acetilcolina, inflamação experimental dos pulmões, mediadores da inflamação. 
Miranda CJCP. Evaluation of lung function and histopathology in an experimental model of chronic allergic pulmonary inflammation: effects of reduced cholinergic function in genetically modified mice [Dissertation]. São Paulo: School of Medicine, University of São Paulo, 2012.

BACKGROUND: Bronchial asthma is characterized by reversible or not airflow obstruction and pulmonary inflammation, mainly characterized by eosinophilia. The persistence of inflammation can induce lung repair process associated with progressive reduction in lung function. Recent evidence of the cholinergic anti-inflammatory system, a neural mechanism that suppresses the innate immune response and control inflammation by proinflammatory cytokines inhibition, and the detection of some of its components in airway cells suggest an important role of this system in pulmonary physiopathology. The main mediator of this system is acetylcholine (ACh), which is stored in synaptic vesicles by vesicular acetylcholine transporter (VAChT), an essential protein for ACh release. AIMS: To evaluate the effects of cholinergic deficiency by VAChT reduction on pulmonary alterations observed in an experimental model of pulmonary inflammation induced by chronic exposure to ovalbumin. METHODS: The cholinergic deficiency was induced by genetic modification on VAChT levels. Wild-type and mutant male mice were submitted to subcutaneous ovalbumin sensitization or saline protocol on days 0,7 and 14. After, animals were submitted to inhalation challenge with ovalbumin $1 \%$ or saline for 20 minutes on days 26, 27 and 28 . On day 29, we evaluated the pulmonary mechanics, inflammation in bronchoalveolar lavage and in airways, histological analysis of airway remodeling and the expression of MMP-9 and TIMP-1 by immunohistochemistry. It was also quantified by the levels of IL-4, IL-10 and TNF- $\alpha$ in lung homogenate. The statistical analysis were performed and a $\mathrm{p}<0.05$ was considered significant. RESULTS: Sensitized animals presented bronchial hyperresponsividade, airway inflammation and edema and collagen and elastic fibers deposition of collagen and elastic fibers around the airways compared to saline group ( $p<0.05)$. Furthermore, there was an increase of IL-4 in lung homogenate and the expression of MMP-9 and TIMP-1 in inflammatory cells. The mutant animals, regardless the sensitization, showed an increase in lung content of TNF- $\alpha$. The mutant and sensitized animals showed an increase in bronchial hyperresponsiveness, in eosinophils, edema and collagen deposition in airways compared to the wild type and sensitized animals. These changes can be attributed to increased IL-4 and MMP-9/TIMP-1 that were observed in mutant and sensitized animals. There was no difference in levels of IL-10 in the experimental groups. Conclusion: The cholinergic deficiency worsens bronchial hyperresponsiveness, eosinophilic inflammation, and airway remodeling mainly by interfering with the pro-inflammatory cytokine IL-4 and in MMP-9/TIMP-1 ratio. These data suggest that anti-inflammatory cholinergic pathway is involved in the asthma pathogenesis deserves further investigation.

DESCRIPTORS: vesicular acetylcholine transporter protein, bronchial asthma, acetylcholine, experimental lung inflammation, inflammatory mediators. 
INTRODUÇÃO

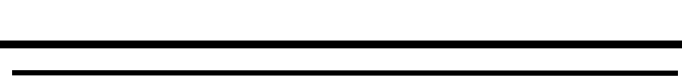




\subsection{ASMA BRÔNQUICA}

\subsubsection{DEFINIÇÃO}

O termo asma vem do verbo grego, aazein que significa exalar com a boca aberta (Marketos e Ballas, 1982). Dos escritos de Hipócrates (460-370 a.c.) aos conhecimentos atuais, sustentados pelo progresso da pesquisa científica no mundo, houve grandes avanços na fisiopatogênese, terapêutica e controle da asma. A definição da asma foi recentemente atualizada em 2011, pela Global Initiative National Of Asthma (GINA), onde:

"A asma é uma desordem crônica inflamatória de vias aéreas onde diversas células e elementos celulares desempenham um papel. A inflamação crônica está associada com a hiperresponsividade das vias aéreas que tem como consequência, episódios recorrentes de sibilos, dispnéia, aperto no peito e tosse particularmente à noite ou no início da manhã. Estes episódios estão normalmente associados à obstrução variável ao fluxo aéreo que é normalmente reversível espontaneamente ou com tratamento".

\subsubsection{ASPECTOS EPIDEMIOLÓGICOS}

Segundo dados da Organização Mundial de Saúde (OMS) revisados em 2010, estima-se que 235 milhões de indivíduos de todas as idades, etnias e países são afetados Pela asma no mundo e que cerca de 250.000 pessoas morrem prematuramente a cada ano como resultado desta doença crônica.

Apesar destes dados alarmantes, as revisões anuais do GINA descrevem a diminuição da mortalidade da asma em países industrializados, 
porém com elevações progressivas na morbidade associada à asma.

A asma é considerada um problema de saúde pública mundial com prevalência global em torno de $1 \%$ a $18 \%$ da população em diferentes países. Todavia a asma é a doença mais comum entre as crianças (Di Lallo et al., 2011). Existem fortes evidências que as diferenças entre os países na prevalência dos sintomas da asma vêm sendo reduzidas, com diminuição desta prevalência na América do Norte e Europa Ocidental e aumento nas regiões onde a prevalência era anteriormente baixa (GINA, 2011).

Até 2025 há uma estimativa de crescimento da população mundial urbana de $45 \%$ para $59 \%$, sugerindo aumentos significativos na prevalência da asma (Bousquet et al., 2007), devido ao aumento da urbanização e ao fato de que as comunidades vem adotando estilos de vida mais ocidentais.

Além disso, a asma gera forte impacto sócio-econômico em todas as comunidades ao redor do mundo devido ao absenteísmo no trabalho, principalmente da população economicamente ativa, e das crianças em idade escolar, além do aumento do gasto familiar e público com medicações e internações frequentes e ainda redução da qualidade de vida do individuo, pois gera distúrbio do sono, fadiga e restrição da atividade física, entre outros (Souza-Machado et al., 2010).

No Brasil foram realizados até os dias de hoje três consensos e diretrizes nacionais para o manejo da asma e segundo a Sociedade Brasileira de Pneumologia, anualmente ocorrem cerca de 350.000 internações, constituindo-se na quarta causa de hospitalização pelo Sistema Único de Saúde (2,3\% do total), e ainda a terceira causa entre crianças e adultos jovens (Ministério da Saúde, 2005). Além disso, neste período, os custos com internações por asma foram de 96 milhões de reais gastos pelos cofres públicos, o que correspondem a $1,4 \%$ do gasto total anual com todas as doenças. 
Considerando os dados catalogados pelo DATASUS (Base de dados do Sistema Único de Saúde), no período de 2000 a 2011, o Brasil vem apresentando grandes avanços no controle e manejo da asma com redução no número de hospitalizações na ordem de 397.333,00 em 2000, para 192.601,00 em 2011 - redução de 51\%. Além disso, enquanto a prevalência da asma vem aumentando em alguns países, no Brasil ela se mantém estável (Di Lallo et al., 2011; Rio et al., 2002).

Acredita-se que este avanço do controle da asma no Brasil, deva-se a melhor compreensão da doença por parte dos portadores e a distribuição de medicamentos de alto custo para os pacientes asmáticos graves, bem como aos programas de atenção primária de educação para asma que estão sendo implantada com sucesso no Brasil, levando a melhor adesão do paciente ao tratamento e consequentemente a redução no número de internações (Silveira et al.,2009; Dalcin et al.,2009). O investimento da renda pública brasileira nos programas de prevenção familiar saltou de 1,8 bilhões em 2003 para 9,6 bilhões em 2010, o que comprova a importância destes programas de atenção primária (Ministério da Saúde, DataSUS, 2011).

No Estado de São Paulo, segundo o Ministério da Saúde 2010, as internações por asma também vem diminuindo progressivamente. No entanto, o ritmo de redução é mais acelerado no interior do que na região metropolitana. Em 1998, o número de internações em todo o Estado era de 38,2 mil, caindo para 17,1 mil em 2009 - redução de 55\%. A capital concentra metade das internações em todo o Estado. Se em 98 as internações por asma na região metropolitana correspondiam a $27 \%$ do total do Estado, em 2009 essa participação saltou para 49\%. Acredita-se que esta estatística na capital deva-se a uma maior precisão no diagnóstico realizado e a poluição ambiental.

Apesar dos avanços no manejo da asma o custo para o seu controle é bastante elevado, porem o custo de não tratar corretamente é ainda maior. (Cooper et al., 2009). Há evidências convincentes de que programas de 
educação para a asma e a inferência do diagnóstico e tratamento precoce podem prevenir a progressão da doença modificando assim a qualidade de vida do paciente (Taylor et al., 2008).

\subsubsection{FATORES DE RISCO}

A asma tem etiologia multifatorial e pode ser dividida entre os fatores que causam o desenvolvimento da asma (fatores genéticos) e aqueles que desencadeiam os sintomas (fatores ambientais), além da associação de ambos os fatores (GINA, 2011; Subbarao et al., 2009).

A identificação de vários genes para a asma ou fenótipos relacionados tem sido foco atual da pesquisa para melhor compreensão da etiologia e fisiopatologia das doenças alérgicas. Há fortes evidências de que a asma é uma doença geneticamente determinada (Howard et al., 2003).

Existe uma extensa variedade de genes envolvidos na susceptibilidade da asma que englobam diversas ações e funções, entre eles: 1) Genes que codificam as moléculas associadas com a imunidade inata e imunorregulação; 2) Genes envolvidos com a diferenciação e função das células efetoras Th2; 3) Genes envolvidos com a biologia e imunidade das células de mucosa; 4) Genes que participam da função pulmonar, gravidade da doença e remodelamento tecidual; e 5) Genes que controlam a contração da musculatura lisa da via área (Vercelli, 2008; Robert et al., 2010).

Dentre os genes identificados, sabe-se que há vários lócus relacionados com a predisposição da asma, como por exemplo, o do receptor para imunoglobulina $E$ ( $\operatorname{lgE}$ ) de alta afinidade $F c \varepsilon R I \beta$ que se relaciona com o cromossomo 11q. Além disso, mutações genéticas do cromossomo 5q contem genes para citocinas como interleucinas (IL): IL-3, 
IL-4, IL-9, IL-12, IL-13 as quais são importantes para o desenvolvimento da inflamação na asma. A IL-4 que está também correlacionada com o cromossomo $16 q$ é uma das principais citocinas responsáveis pela diferenciação linfocitária Th2 e pelo estímulo à produção de $\lg \mathrm{E}$ (Walley et al., 1996; Martinez et al., 1998). Existe correlação entre a eosinofilia e o cromossomo $6 \mathrm{q}$, o receptor de células $\mathrm{T}$ ao cromossomo 14 , interferon $-\mathrm{Y}$ (IFN-Y) e o fator de crescimento dos mastócitos com o cromossomo 12 e ainda a ligação do cromossomo $5 q$ com a hiperresponsividade brônquica (Postma et al.,1995).

Além dos fatores genéticos, é de grande relevância destacar os fatores ambientais, que podem agir em conjunto ou isoladamente aos genéticos, e que quando associados são responsáveis pelas formas mais graves da asma. Os estímulos para desencadear a hiperresponsividade observada na asma brônquica são diversos, entre eles, drogas, estresse, exercício físico, poluentes atmosféricos, alérgenos, estímulos ocupacionais, tabagismo passivo e ativo, entre outros, como demonstrado na Tabela 1. 
Tabela 1: Fatores que influenciam o desenvolvimento e a expressão da asma.

\section{FATORES INDIVIDUAIS}

-Genéticos: Pré-disposição a atopia e a hiperresponsividade

-Obesidade

-Sexo

\section{FATORES AMBIENTAIS}

\section{ALÉRGENOS}

-Domésticos: Ácaros, animais (cães, gatos, ratos), fungos,mofo

-Externos: Pólen, fungos,leveduras,mofo, hifas

\section{AGENTES OCUPACIONAIS}

-Tabaco: Fumantes ativos e passivos

-Poluentes: Domésticos e ambientais

-Infecções: predominantemente viral

-Dieta

-Drogas

FATORES QUE PRECIPITAM A EXACERBAÇÃO DA ASMA E/OU CAUSA PERSISTÊNCIA DOS SINTOMAS

-Alérgenos domésticos e externos

-Poluentes domésticos e externos

-Infecções respiratórias

-Exercício e hiperventilação

-Mudanças climáticas

-Dióxido de enxofre

-Comidas, aditivos, drogas

-Condição emocional

-Fumaça do cigarro

-Irritantes inalatórios com sprays, tintas e outros

Fonte: GINA 2011 


\subsubsection{FISIOPATOLOGIA DA ASMA}

A asma é um distúrbio inflamatório das vias aéreas que envolve diversas células inflamatórias e múltiplos mediadores, os quais resultam nas suas características fisiopatológicas (Bafadhel et al., 2012). O padrão inflamatório da asma esta fortemente associado com a hiperresponsividade das vias aéreas e a seus sintomas clínicos (Brannan, 2010).

O processo de sensibilização da doença representa a primeira etapa para o desenvolvimento do quadro asmático. Para que este processo ocorra, os alérgenos inalados entram inicialmente em contato com a mucosa respiratória e são capturados por células dendríticas presentes no epitélio brônquico. Estas células, incluindo no caso do pulmão os macrófagos alveolares, são capazes de reconhecer, processar o antígeno e apresentar seus fragmentos peptídicos ligados à molécula do complexo principal de histocompatibilidade classe II (MHC II) aos linfócitos T auxiliares (Hawrylowic e O'Garra, 2005).

Os linfócitos T CD4+, em indivíduos com pré-disposição genética, se diferenciam em linfócitos Th2 produzindo um padrão de citocinas, sobretudo as IL-3, IL-4, IL-5, IL-9, IL-10, IL-13, que caracterizam a resposta predominantemente humoral.

As citocinas produzidas pelos linfócitos $T$ fazem com que estas células estimulem a produção de IgE por linfócitos B (fase de sensibilização alérgica), além de estimular a proliferação de mastócitos e ativação e aumento da sobrevida dos eosinófilos. Estudos epidemiológicos e observações clínicas apontam uma importante correlação entre os níveis de anticorpos IgE e a gravidade da asma (Varner e Lemanske, 2000).

Após a sensibilização do indivíduo e frente à nova exposição ao antígeno, a lgE liga-se aos receptores de alta afinidade expressos em mastócitos e basófilos (Harris et al.,1995), o que induz a desgranulação 
mastocitária com consequente liberação de mediadores pró-inflamatórios como histamina, citocinas e leucotrienos que atuam aumentando a permeabilidade das células epiteliais, entre outros fatores. Neste momento, o antígeno pode então, atingir a mucosa e ativar mastócitos e eosinófilos que, por sua vez, liberam mais mediadores, perpetuando assim a cascata inflamatória.

De modo geral, como podemos observar na Figura 1, a resposta asmática pode ser dividida em duas fases, uma que ocorre minutos após o contato com o antígeno (resposta alérgica imediata) e outra que ocorre horas após a exposição (resposta alérgica tardia).

Deste modo, a resposta asmática imediata é caracterizada pela desgranulação mastocitária e liberação de mediadores pró-inflamatórios que promovem, do ponto de vista histopatológico, aumento da permeabilidade vascular, contração do músculo liso, edema de mucosa e produção de muco, sendo responsáveis conjuntamente pelos sintomas de sibilos, tosse, rinorréia e falta de ar. Nesta fase a principal característica da resposta asmática é a hiperresponsividade brônquica.

O início da fase tardia é sinalizado pela chegada de leucócitos recrutados (neutrófilos, eosinófilos, basófilos e também linfócitos e monócitos). Nesta fase, ocorre a liberação de mediadores produzidos por leucócitos, pelo endotélio e por células epiteliais. Dentre estes, os eosinófilos causam importante dano ao epitélio, devido à liberação pelos seus grânulos da proteína básica principal e a proteína catiônica eosinofílica. Esta fase é marcada pelo grande influxo de eosinófilos para as vias aéreas e liberação de mediadores pró-inflamatórios (Homma et al., 2005; Hawrylowicz e O'Garra, 2005) (Figura 1). 


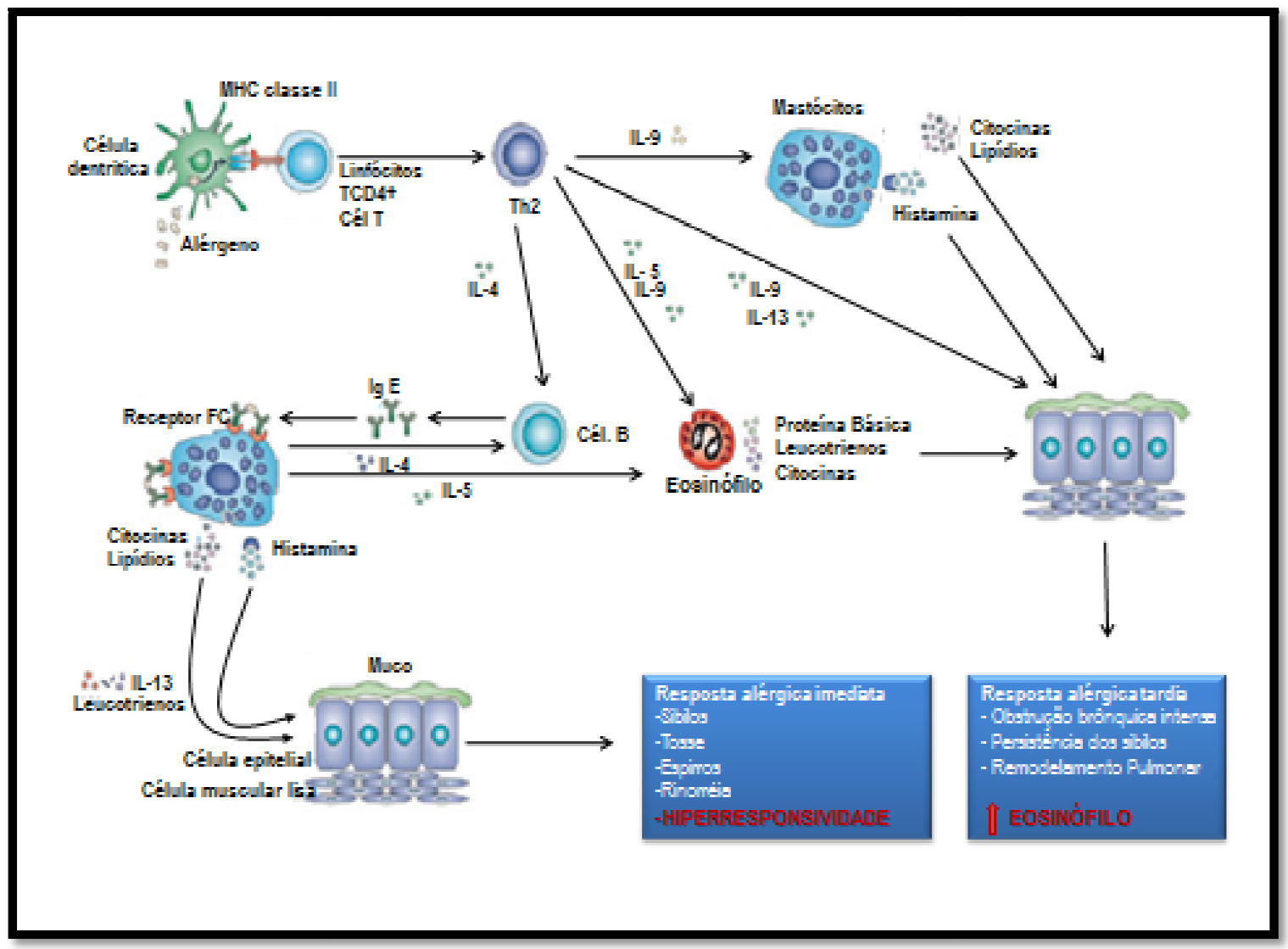

Figura 1. Fisiopatogenia da asma. $O$ individuo asmático traz consigo o gene que o deixa mais susceptível a estímulos exógenos. Ao entrar em contato com o antígeno, as células dendríticas e os macrófagos alveolares, que são apresentadoras de antígeno, ativam os linfócitos TCD4+ os quais se diferencial em linfócitos de classe Th2. Estes, na presença principalmente de IL4, estimulam os linfócitos $B$ a fazerem síntese de lgE (fase de sensibilização alérgica). Com exposições subsequentes e repetidas ao alérgeno, a lgE liga-se aos receptores de alta afinidade expressos em mastócitos e basófilos. Estas células, por sua vez, sofrem desgranulação e liberam mediadores pró-inflamatórios como histamina, citocinas e leucotrienos que promovem 0 aumento da permeabilidade vascular, contração do músculo liso e produção de muco gerando os sintomas da fase imediata (sibilos, tosse, espirro e rinorréia). A característica marcante desta fase é a hiperresponsividade brônquica. $\mathrm{Na}$ fase tardia o linfócito Th2 juntamente com os mastócitos ativam os eosinófilos que liberam uma nova cascata de mediadores pró-inflamatórios promovendo os sintomas da fase tardia como: obstrução brônquica intensa, persistência dos sibilos e remodelamento pulmonar. Esta fase é caracterizada pelo grande influxo de eosinófilo e outras células inflamatórias para as vias aéreas. (Adaptado de Hawrylowicz e O'Garra, 2005). 
A persistência do processo inflamatório e o desencadeamento de várias respostas tardias podem culminar para um processo de reparo crônico de natureza progressiva, conhecido como remodelamento pulmonar (De Kluijver et al., 2005).

Neste sentido, Mauad et al. (2007) descrevem que o remodelamento pulmonar em pacientes com asma crônica envolve mudanças em toda arquitetura das vias aéreas e é tipicamente associado com: hiperplasia e hipertrofia das células caliciformes, hipertrofia epitelial e muscular dos brônquios; aumento na produção de citocinas e quimiocinas pelas células epiteliais; intensa infiltração intraepitelial de eosinófilos, aumento na deposição dos componentes da matriz extracelular (MEC), entre eles fibras colágenas e elásticas; proliferação dos fibroblastos, desenvolvimento de miofibroblastos e aumento da vascularidade. A consequência mais drástica do processo de remodelamento é a limitação crônica ao fluxo aéreo que ao longo dos anos culmina com o declínio irreversível da função pulmonar observada nos pacientes asmáticos (Postma e Timens, 2006).

Considerando o sistema de fibras elásticas, não há um consenso sobre o exato processo de reparo destas fibras no remodelamento pulmonar. Mauad et al. (1999) demonstraram que há elastólise nas vias aéreas de asmáticos, sugerindo com isso que as fibras do sistema elástico participam do remodelamento das vias aéreas na asma, e que a ruptura das fibras ancoradas à membrana basal, na camada superficial, poderia prejudicar o mecanismo de recolhimento pulmonar em pacientes asmáticos.

O processo de remodelamento pulmonar, envolve um constante processo de reparo e regeneração dos componentes da MEC, é controlado pelo equilíbrio de fatores pró-e anti-fibróticos. Dentre estes fatores se destacam as metaloproteinases (MMP's) e seus inibidores teciduais (TIMPs), que podem estar alterados na asma.

As MMP's são uma classe de proteínas que possuem a função de 
regular a composição química da MEC, tanto em condições fisiológicas como patológicas (Parks e Shapiro, 2001). Elas são divididas em subclasses que levam em consideração o seu substrato, sendo elas colagenases (MMP1, MMP-8 e MMP-13), gelatinases (MMP-2 e MMP-9), estremelisinas (MMP3, MMP-10 e MMP-11), matrilisinas (MMP-7), metaloelastase macrofágica (MMP12), MMPs de membrana (MMP14, MMP15, MM-16 e MMP17) entre outras (Greenlee et al., 2007) e são sintetizadas na sua forma inativa. Diversos estímulos podem estar envolvidos no processo de ativação, dentre eles, o aumento da responsividade gênica a fatores oncogenes, fatores de crescimento, citocinas, hormônios, espécies reativas de oxigênio (ERO), a alterações de pH e de temperatura (Gueders et al., 2006).

A MMP-9 é ativada em todos os processos de remodelamento e reparo, e também em condições inflamatórias. É produzida principalmente por células inflamatórias, como macrófagos, neutrófilos e eosinófilos, e esta associada ao remodelamento pulmonar devido aos processos inflamatórios (Parks e Shapiro, 2001). Estes dados sugerem que a MMP-9 tem grande importância na asma

As drogas recomendadas pelos consensos mais atuais para a asma são os corticosteroides. Seu uso está associado a redução do processo inflamatório e a redução da mortalidade e da freqüência das hospitalizações. Embora alguns autores tenham mostrado que o uso adequado de corticosteroides seja capaz de retardar o declínio da função pulmonar (Bateman et al., 2008), outros não mostraram efeito deste tratamento no processo de remodelamento (Buc et al., 2009). Além disso, o uso desta classe de fármacos está relacionado a efeitos adversos, mesmo quando administrado de forma inalatória (Ernst e Suissa, 2012). Pacientes com asma grave, muitas vezes não respondem ao uso de corticosteróides (Ito et al.,2006) e necessitam de altas doses, o que tem associação direta a diversas co-morbidades como a diabetes, glaucoma, tuberculose, entre outras (Ernst e Suissa, 2012). 


\subsubsection{INFLAMAÇÃO E MEDIADORES ENVOLVIDOS NA ASMA}

A inflamação está no cerne de diversas doenças crônicas pulmonares, inclusive a asma. A interação de diferentes tipos celulares e mediadores é fundamental para que ocorram as alterações características da inflamação e do processo de remodelamento tecidual observados na asma brônquica.

A integração e o produto dessas células e mediadores envolvidos na inflamação típica da asma incluem citocinas como as IL-1, IL-2, IL-3, IL-4, IL5, IL-6, IL-10, IL-12, IL-13, fator estimulador de colônias de granulócitosmacrófagos (GM-CSF), fator de necrose tumoral (TNF- $\alpha$ ); fator transformador do crescimento beta (TGF- $\beta$ ), ERO, produtos granulares préformados (proteína básica principal do eosinófilo e proteína catiônica eosinofílica), histamina e triptase do mastócito, mediadores lipídicos que incluem as prostaglandinas, os leucotrienos e o fator de ativação das plaquetas (PAF), moléculas de adesão intracelular -1 (ICAM-1) e vascular-1 (VCAM-1) e óxido nítrico (Lemanske et al., 2006; Woodfolk, 2006 ).

Entre as várias células que participam do processo inflamatório na asma, estudos demonstram que o linfócito $\mathrm{T}$ e o eosinófilo atuam como células fundamentais para perpetuação do processo inflamatório. Os linfócitos são classificados pela molécula que expressam em sua superfície, e no caso das células $T$, são subclassificadas pelas citocinas que secretam. De forma geral, os linfócitos Th1 produzem IL-2 e IFN-Y, que são essenciais para os mecanismos de defesa do organismo. Em contraste, as células Th2 produzem citocinas como a IL-4, IL-5, IL-6, IL-9 e IL13, que são mediadores da resposta inflamatória alérgica. Ocorre ainda uma inibição recíproca entre as subpopulações linfocitárias, o que suporta a hipótese de a asma ser derivada de um desequilíbrio entre as células Th1 e Th2. Além disso, existe 
uma correlação entre a gravidade da asma e os linfócitos T ativados e eosinófilos no lavado broncoalveolar (LBA) (Walker et al., 1991).

À semelhança da imunoglobulina lgE, os eosinófilos tem um papel fundamental na asma. Estão presentes nas vias aéreas de pacientes asmáticos em quantidades variáveis e são praticamente ausentes em indivíduos normais. Estas células, uma vez recrutadas e ativadas no tecido pulmonar inflamado, têm papel efetor, liberando proteínas altamente tóxicas de seus grânulos como a proteína básica principal, proteína catiônica eosinofílica, a peroxidase eosinofílica, e ERO responsáveis por graves danos no tecido pulmonar (Busse e Lemanske, 2001; Hogan et al., 2008). A proteína básica principal possui característica única, além de causar dano epitelial, pode intensificar a hiperresponsividade brônquica, e causar desgranulação de basófilos e mastócitos.

Considerando a participação dos eosinófilos no estresse oxidativo, há evidências que estas células participam da liberação de ERO, eicosanóides e citocinas da classe Th2. Os eosinófilos obtidos de pacientes asmáticos produzem mais ânion superóxido quando comparados a indivíduos saudáveis (Ying et al., 1995). A produção excessiva de ERO pode causar inflamação no tecido pulmonar e hiperreatividade das vias aéreas, exacerbando o quadro fisiopatológico da asma (Caramori e Papi, 2004).

Os eosinófilos contribuem para o processo de fibrose tecidual e remodelamento das vias aéreas, devido à liberação de fatores do crescimento, elastase, fibroblastos, metaloproteinases e também por estimulação dos fibroblastos (Hall e Walport, 1993). Além disso, produzem mediadores lipídicos que vão amplificar a resposta inflamatória através do recrutamento e ativação de mais células (Auchinlos et al.,1997).

Os macrófagos são produzidos por células progenitoras originadas na medula óssea comum para granulócitos e monócitos que atuam na imunidade específica. Os macrófagos alveolares são derivados de 
monócitos sanguíneos e da proliferação de células precursoras presentes no interstício pulmonar. Estão aumentados nas vias aéreas (GINA, 2010) e podem ser ativados por alérgenos, através do receptor de baixa afinidade $\lg \mathrm{E}$, liberando assim mediadores inflamatórios e citocinas que amplificam a resposta inflamatória (Wenzel, 2003).

Os mastócitos quando estimulados sofrem desgranulação e liberam mediadores broncoconstritores como a histamina, cisteína, leucotrienos e prostaglandinas D2. O número de mastócitos está aumentado na parede das vias aéreas e participam efetivamente do quadro de hiperresponsividade (Robinson, 2004)

A atuação dos neutrófilos na fisiopatologia da asma é pouco esclarecida. Encontram-se normalmente aumentados nas vias aéreas e no escarro de pacientes com asma severa e fumantes asmáticos, porem acredita-se que este aumento, seja devido ao uso de terapia com glucocorticosteróide (Wenzel et al.,1999, Chung, 2000).

Nadel e Takeyama (1999) relataram que os neutrófilos desempenham um papel importante no estímulo do aumento da secreção por células caliciformes e glândulas submucosas das vias aéreas. Outros autores, no entanto, não encontraram correlação significativa entre o número de neutrófilos presentes no tecido periglandular e a presença de muco na luz das vias aéreas (Carrol et al., 1996).

As citocinas modulam inúmeras as atividades funcionais das células e dos tecidos, têm a capacidade de mediar interações diretas das células e de atuar como fator de sobrevivência celular, prevenindo a apoptose. Agem ainda no controle da ativação, proliferação, quimiotaxia, imunomodulação e liberação de outras citocinas e mediadores inflamatórios. Sob o prisma da asma perpetuam a resposta inflamatória, suas principais funções estão resumidas na Tabela 2. Além de orquestrar toda a cascata inflamatória, as citocinas ainda determinam o grau de severidade da asma (Barnes, 2002). 
São também mediadores principais da resposta inflamatória as citocinas IL-1 $\beta$ e TNF- $\alpha$, que amplificam a resposta inflamatória e o GM-CSF que prolonga a sobrevivência dos eosinófilos (GINA, 2011). Além disso, temos as citocinas de classe Th2 como a IL-5 que é necessária para a estimula a diferenciação, proliferação, sobrevivência e ativação dos eosinófilos na medula óssea e circulação sanguínea (Hogan et al., 2008).

A IL-4 é considerada por diversos autores como mediador central da inflamação alérgica das vias aéreas por perpetuar a ativação dos mastócitos, que atuam no aumento da produção de IgE específico ao alérgeno, no recrutamento e maturação de eosinófilos, por aumentarem a expressão da molécula de adesão -1 (VCAM-1) no endotélio e ainda participarem na estimulação de células epiteliais para produzir muco (Moser et al.,1992; Larche et al.,2003). Schleimer et al. (1992) demonstraram a habilidade da IL4 em induzir o recrutamento seletivo dos granulócitos em reações alérgicas in vivo. Em modelo de inflamação de vias aéreas em camundongo a IL-4 atua na regulação do recrutamento eosinofílico por um mecanismo linfócito T-dependente (Brusselle et al., 1994).

Outros mediadores liberados pelas células inflamatórias envolvidas na fisiopatogenia da asma também tem sua importância destacada. A histamina é uma amina biogênica chave envolvida nas reações alérgicas. Além disso, este mediador é liberado pelos mastócitos e contribui tanto para broncoconstrição quanto para resposta inflamatória. 
Tabela 2. Principais citocinas que participam do processo inflamatório da asma

\begin{tabular}{|c|c|}
\hline Citocina & Atividade biológica \\
\hline IFN- $\gamma$ & $\begin{array}{c}\text { Citocina mais importante na imunidade mediada por } \\
\text { células; controla o equilíbrio Th1/Th2; inibe a resposta } \\
\text { alérgica }\end{array}$ \\
\hline IL-10 & Antiinflamatória \\
\hline IL-13 & $\begin{array}{l}\text { Produção de } \lg \mathrm{E} \text {, inflamação, hipersecreção de muco, } \\
\text { eosinofilia }\end{array}$ \\
\hline $\mathrm{IL}-4$ & $\begin{array}{l}\text { Regulação do crescimento, diferenciação, ativação e } \\
\text { função de células B }\end{array}$ \\
\hline IL-5 & Eosinofilia e regulação de eosinófilos \\
\hline TGF- $\beta$ & $\begin{array}{l}\text { Remodelamento; citocina pró-fibrótica; quimiotática } \\
\text { para muitas células inflamatórias }\end{array}$ \\
\hline
\end{tabular}

Fonte: Hamid e Tulic (2009)

O óxido nítrico é um neurotransmissor endógeno não adrenérgico não colinérgico (NANC) em vias aéreas responsáveis pela modulação do tônus brônquico (Barnes; Belvisi,1993), tônus vascular (Alving et al.,1992) e exsudação plasmática (Kuo et al.,1992) tanto em modelos animais quanto em humanos. Parece atuar em vários mecanismos fisiopatológicos que desencadeiam as alterações funcionais e histopatológicas encontradas nos pacientes asmáticos, sendo que a sua contribuição depende principalmente da enzima pela qual foi produzido. A grande quantidade de NO oriundo da enzima iNOS (isoforma induzida) pode resultar em vasodilatação, extravasamento de plasma, aumento da secreção do muco, ativação indireta de células Th2 e remodelamento de vias aéreas contribuindo para a fisiopatologia da asma (Prado et al.,2005; Prado et al.,2006b, Starling et al., 2009). 
O papel dos leucotrienos cisteínicos na fisiopatologia da asma ainda é controverso. Waseda et al. (2011) mostraram que os leucotrienos estão envolvidos no controle da responsividade secundária ao desafio antigênico principalmente na resposta tardia. No entanto, outros autores não mostraram a efetividade do tratamento com anti-leucotrienos na asma, particularmente quando comparado aos efeitos dos corticosteróides, que parecem ser mais potentes (Bleecker et al., 2000, Leick-Maldonado et al., 2004).

Ainda há muito a compreender sobre os imbricados e complexos mecanismos celulares e moleculares envolvidos na patogênese da asma. Sabe-se que diversas células estão envolvidas, uma gama de mediadores são liberados, e estes estão constantemente interligados em suas funções. Por estes motivos, o processo de inflamação/reparo na asma é um mecanismo cíclico que culmina com a perpetuação da resposta inflamatória e com o remodelamento brônquico.

\subsection{ACETILCOLINA E PULMÃO}

Quimicamente a acetilcolina (ACh) é um éster de ácido acético e colina, cuja simplicidade estrutural subestima a complexidade das ações que exerce. Via sistema nervoso autônomo pulmonar, a acetilcolina é liberada nas fibras pré-ganglionares do sistema nervoso adrenérgico e principalmente nas fibras pré e pós-ganglionares do sistema nervoso colinérgico (Richardson, 1991).

A ACh é sintetizada no terminal nervoso colinérgico a partir do substrato de acetil-CoA e colina, uma ação catalisada pela enzima acetiltransferase e posteriormente transportada para o interior das vesículas sinápticas pelo transportador vesicular de acetilcolina (VAChT). As vesículas sinápticas liberam, por exocitose, ACh na fenda sináptica (Prado et al., 2002). Ao ser liberada na fenda sináptica, a ACh interage com os receptores 
muscarínicos e nicotínicos. Após a dissociação dos respectivos receptores, a ACh é hidrolisada pela ação da enzima acetilcolinesterase em colina e acetato. A colina é recaptada pelo transportador de colina de alta afinidade (CHT1) (Ribeiro et al., 2006) para síntese de novas moléculas de acetilcolina (Figura 2).

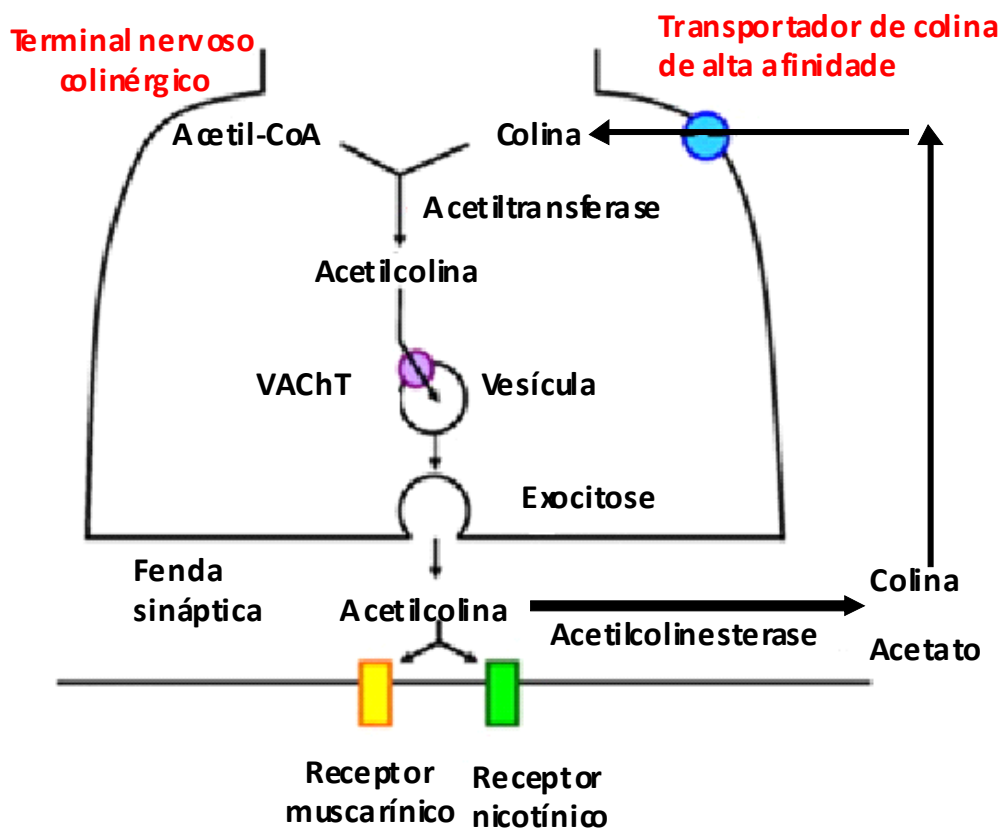

Figura 2: Síntese de Acetilcolina. A ACh é sintetizada no terminal nervoso colinérgico a partir do substrato de acetil-coA e colina, um ação catalisada pela enzima acetiltranferase e posteriormente é transportada para o interior das vesículas sinápticas pelo transportador vesicular de acetilcolina (VAChT). As vesículas sinápticas por exocitose liberam ACh na fenda sináptica. Ao ser liberada na fenda sináptica a $A C h$ interage com os receptores muscarínicos e nicotínicos e sequencialmente é hidrolisada pela enzima acetilcolinesterase em colina e acetato. A colina é recaptada pelo transportador de colina de alta afinidade ( $\mathrm{CHT} 1)$ para síntese de novas moléculas de ACh (Desenho esquemático representando a neurotransmissão colinérgica -(Modificado de Gwilt et al. (2007).

Dos componentes do sistema colinérgico o mais importante para 0 controle da liberação da ACh é o VAChT que, se inibido, compromete a liberação da ACh na fenda sináptica e consequentemente sua interação com os receptores muscarínicos e nicotínicos (Lima et al., 2010). 
No pulmão, a inervação colinérgica se dá principalmente pelos nervos parassimpáticos que atingem este órgão via nervo vago e tem sua predominância em vias aéreas proximais. O nervo vago surge no tronco cerebral e se dirigem até os pulmões através de suas fibras, fazendo sinapses com os gânglios embutidos ou expressos na parede da via aérea, traquéias e brônquios para dar origem a fibras pós-ganglionares e inervar as glândulas submucosas, vasos sanguíneos e músculo liso das vias aéreas (Gwilt et al., 2007). É importante ressaltar que a inervação parassimpática é predominante na via aérea e seu principal neurotransmissor e neuromodulador é a acetilcolina, como pode ser observado na Figura 3.

A detecção dos componentes do sistema colinérgico, tais como a ACh, CHT1, a colina acetiltransferase, VAChT, a acetilcolinesterase e receptores de acetilcolina em células inflamatórias de vias aéreas sugerem uma importante participação do sistema colinérgico na fisiopatologia das doenças pulmonares (Kawashima, Fujii, 2004; Wessler et al., 1998).

Sabe-se que a captação da colina nas células epiteliais de vias aéreas é regulada pelo $\mathrm{CHT} 1$ e transportadores específicos da colina (Kummer et al., 2008; Lips et al., 2005). O transportador de colina tipo 1 e 2 tem papel fundamental na liberação de ACh pelas células epiteliais das vias aéreas. Além disso, a expressão da VAChT em alguns tipo de células epiteliais foi demonstrado, sugerindo que a o estoque e a liberação de ACh no pulmão dependam da VAChT mesmo em células não neuronais (Kummer et al., 2008; Lips et al., 2005). A expressão da VAChT também já foi detectada em outros órgãos além dos pulmões (Maeda et al., 2011), em células que não fazem parte do sistema nervoso, sugerindo que esta proteína atue tanto na liberação colinérgica neuronal quanto na não neuronal. Diversos tipo de células do sistema immune também produzem ACh e esta já foi detectada em macrófagos alveolares humanos (Wessler et al., 1998). 


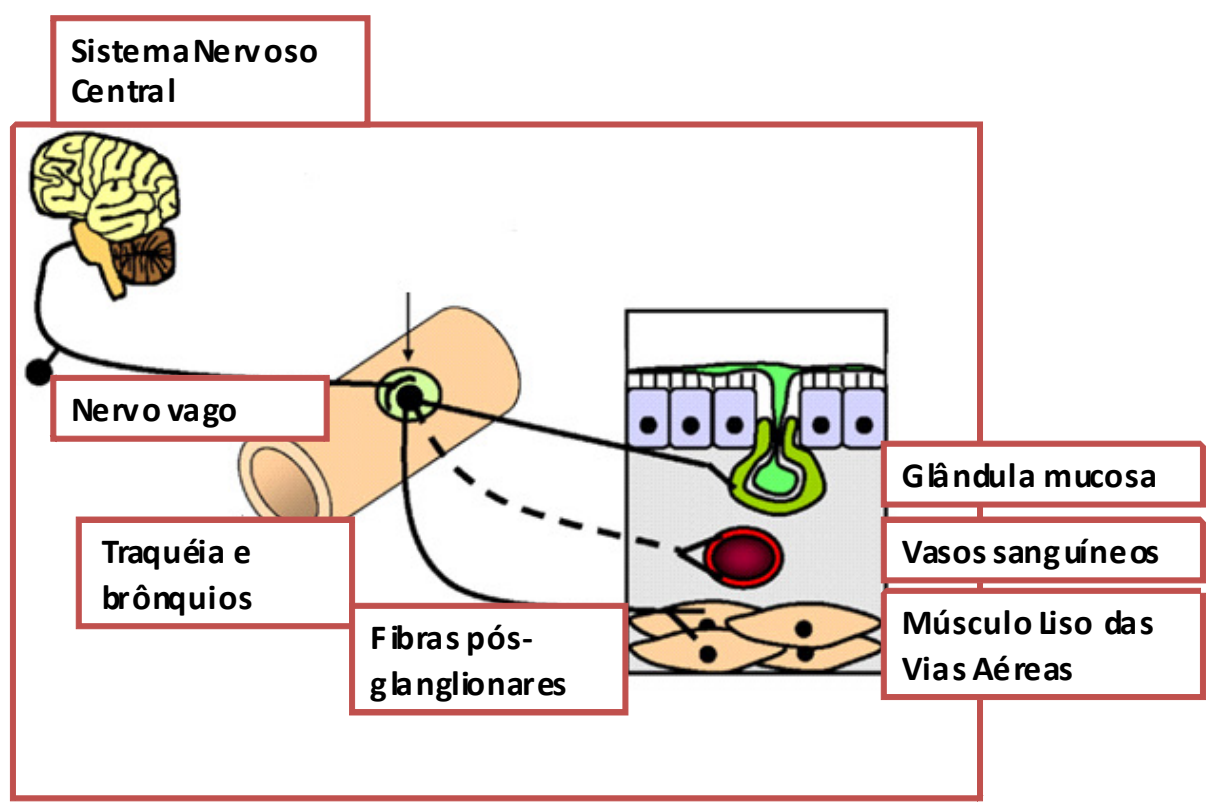

Figura 3. Inervação Parassimpática dos pulmões. Nos pulmões, a inervação colinérgica das vias aéreas se dá principalmente pelos nervos parassimpáticos que atingem este órgão via nervo vago e tem sua predominância em vias aéreas proximais. O nervo vago surge no tronco cerebral e se dirigem até os pulmões por meio de suas fibras e fazem sinapse com gânglios embutidos ou expressos na parede da via aérea, traquéias e brônquios para dar origem a fibras pós-ganglionares e inervar as glândulas submucosas, vasos sanguíneos e músculo liso das vias aéreas (Adaptado de Gwilt et al. (2007).

\subsubsection{RECEPTORES MUSCARÍNICOS}

Os receptores muscarínicos (MAChRs) são do tipo serpentiforme que transpassam a membrana sete vezes e estão acoplados a proteína $G$ (Gosens et al.,2008) No pulmão, a ACh é um potente broncoconstritor, principalmente quando se liga a receptores muscarínicos encontrados na 
musculatura lisa das vias aéreas (Gosen et al., 2008). Por este motivo, anticolinérgicos, particularmente antagonista de receptores muscarínicos, são amplamente utilizados no tratamento de doenças respiratórias como broncodilatadores.

Existem cinco subtipos de receptores muscarínicos (M1 - M5,) dos quais três exercem efeitos fisiológicos nas vias aéreas (M1, M2, e M3). A musculatura lisa das vias aéreas contem M2 e M3 (Coulson et al., 2003), sendo que a principal função destes, é atuar nos mecanismos de contração das vias aéreas. Já foi descrito a expressão de receptores muscarínicos em diversos tipos de células inflamatórias e também em células estruturais das vias áereas (Gosens et al., 2008).

Neste sentido, Struckmann et al. (2003) usando videomicroscopia, comparou a constrição de vias aéreas periféricas in vitro utilizando murinos Knockout para M2, M3 isoladamente e Knockout duplo (M2 e M3). Os autores observaram que a constrição foi abolida nos animais Knockout duplo (M2 e M3), foi reduzida em $60 \%$ nos animais Knockout para M3 e que houve redução da broncoconstrição em animais Knockout para $\mathrm{M} 2$, sendo esta inferior a observada nos animais Knockout para M3. Estes dados sugerem que a constrição colinérgica em modelo murino seja mediada pela concentração dos subtipos M2 e M3.

A regulação da contração do músculo liso das vias aéreas é feita por fibras nervosas do sistema parassimpático (Coulson, Fryer, 2003). A ativação do nervo vago libera $\mathrm{ACh}$, a qual se liga aos receptores muscarínicos do tipo M3 (M3AChR) localizados nas células musculares para causar contração do músculo liso tanto em humanos (Roffel et al., 1988) quanto em animais (Eglen et al.,1996). De outro modo, a ACh interage também com os receptores muscarínicos do tipo 2 (M2AChR) localizados nos nervos colinérgicos pós- ganglionares e, a ativação destes receptores, inibe a liberação da $\mathrm{ACh}$ em um mecanismo de retroalimentação negativa diminuindo assim a broncoconstrição (Fryer e Jacoby , 1998). Na presença 
de doenças pulmonares como a asma, ocorre diminuição na expressão dos receptores M2AChR, o que pode gerar intensa hiperrresponsividade brônquica (Fryer e Jacoby, 1998).

Os receptores M3AChR estão expressos na musculatura lisa das vias aéreas, no epitélio das glândulas submucosas e em células inflamatórias. Embora sejam expressos em menor quantidade que os M2 na proporção de 4:1 (Roffel et al.,1988), induzem intensa broncoconstrição ao interagir com a ACh na musculatura lisa das vias aéreas. Além disso, estão também envolvidos no aumento da produção de muco pelo epitélio glandular participando assim efetivamente da fisiopatologia da asma.

Recentemente, tem sido mostrado que a acetilcolina, agindo sobre os receptores muscarínicos, também está envolvida na piora da inflamação das vias aéreas e no remodelamento pulmonar (Kistemaker et al., 2012). Os mecanismos pelos quais os receptores muscarínicos regulam as respostas inflamatórias e fibróticas não estão ainda totalmente esclarecidos (Tjitske et al., 2010). Cabe ressaltar que os receptores muscarínicos são os principais alvos dos anticolinérgicos utilizados nas doenças pulmonares obstrutivas. Além disso, a ACh produzida principalmente pelas células epiteliais das vias aéreas e atuando via receptores muscarínicos (Proskocil et al., 2004, Kummer et al., 2006), regula a proliferação e estimula a secreção de cloreto, a produção de citocinas e a frequência do batimento ciliar (Metzen et al., 2003).

Assim, um estudo publicado por Cao et al. (2011) utilizou um antagonista especifico para o receptor muscarínico M3 em modelo experimental de asma, observando redução da hiperresponsividade, das células totais, dos eosinófilos no LBA e da síntese de citocinas (IL-5 e IL-4 e MMP-9). Além disso, na análise histopatológica foi constatado redução do infiltrado dos eosinófilos no tecido, na produção de muco nas vias aéreas e da deposição do colágeno nos tecidos pulmonares, corroborando a ideia de que os receptores muscarínicos estão envolvidos na resposta inflamatória. 


\subsubsection{SISTEMA COLINÉRGICO ANTIINFLAMATÓRIO E RECEPTORES NICOTÍNICOS}

Nos últimos anos, incessantes pesquisas sobre a causa base da inflamação e seus efeitos na saúde humana trouxe uma compreensão mais arraigada do funcionamento do processo inflamatório e principalmente de como ele está associado a muitas doenças debilitantes do nosso tempo como a diabetes, obesidade, artrites, câncer, fibrose cística, asma, entre outras (Merouane et al., 2011).

A inflamação é uma resposta fisiológica frente à invasão de um patógeno e/ou a injúria tecidual que se manifesta clinicamente por seus sinais clássicos: "dor, calor, rubor, e tumor". Qualquer órgão ou tecido do corpo pode se tornar inflamado, envolvendo uma cascata de eventos que começa com uma resposta localizada e altamente regulada. O objetivo desta resposta é localizar, neutralizar e eliminar o agente agressor, além de promover o reparo aos danos causados (Pavlov e Tracey, 2006).

O tecido, ao sofrer uma injuria causada por trauma, infecção, isquemia ou hipersensibilidade imunológica, irá desencadear uma resposta inflamatória, que via de regra é caracterizada pela liberação de mediadores pró-inflamatórios como citocinas ou interleucinas (TNF- $\alpha$ ou a IL-1 $\beta$ ), moléculas de adesão, mediadores vasoativos, ERO, entre outros (Commins et al., 2010 ). Seguido a este evento, ocorre a migração de células inflamatórias como neutrófilos, monócitos, linfócitos e eosinófilos e que finda com a resolução da injúria, remoção das células inflamatórias e reparo tecidual.

Embora as respostas inflamatórias à injúria tecidual tenha o intuito do reparo, uma inflamação persistente terá um efeito devastador que pode levar à debilidade e a morte. Neste sentido, é necessário um ajuste equilibrado 
entre a produção de citocinas anti e pró-inflamatória. Quando produzidas em excesso, as citocinas podem acarretar um panorama favorável para uma série de doenças crônicas, inclusive a asma (Gwilt et al., 2007). A magnitude da resposta inflamatória é finamente controlada e auto-regulada por uma série de mecanismos que incluem as interações neuro-imuno-inata (Puerta e Pavlov, 2007).

A via colinérgica antiinflamatória, um reflexo composto pelo nervo vago e seu principal neurotransmissor a ACh, é um mecanismo de autoregulação da inflamação local e sistêmica. Esta via foi descoberta por Borovikova et al. (2000), onde os autores descreveram o arco reflexo da inflamação. Durante o processo inflamatório, as fibras sensitivas do nervo vago, as quais atuam em vários órgãos como fígado, pulmão, baço, rins e intestino, iniciam uma resposta reflexa estimulada pela liberação de mediadores químicos (TNF- $\alpha$ e IL1- $\beta$ ) oriundos do sítio inflamatório (Wang et al., 2009). Estes estímulos são transmitidos ao sistema nervoso central, via braço aferente vagal, fazem sinapse no núcleo do trato solitário que, juntamente com outras estruturas centrais, ativam os neurônios vagais eferentes (Figura 4).

O arco eferente motor denomina-se "via colinérgica antiinflamatória", pois potenciais de ação transmitidos à periferia pelo nervo vago resultam na liberação de ACh (Johnston, Webster, 2009) que ao se ligar com receptores nicotínicos presentes em macrófagos e outros tipos celulares, inibem a síntese de citocinas pró-inflamatórias, prevenindo assim o dano tecidual (Johnston, Webster, 2009; Wang et al., 2009) (Figura 4). Nos últimos anos diversos estudos focaram em demonstrar a expressão e a função do sistema colinérgico anti-inflamatório em diferentes situações patológicas (RosasBallina(a) et al., 2009; Tracey, 2007).

Desde a descoberta da via colinérgica antiinflamatória uma verdadeira orquestra de estudos clínicos e experimentais vem incessantemente sendo realizados no intuito de compreender como a ACh desempenha este papel 
antiinflamatório. Neste sentido, são utilizados diferentes modelos de ativação ou inibição da via colinérgica anti-inflamatória, sendo por estimulação elétrica do nervo vago, vagotomia ou uso de fármacos que inibam a acetilcolinesterase ou agonistas e/ou antagonistas de receptores específicos. No entanto, considerando a abundância dos receptores da acetilcolina, estudos de receptores individuais podem não revelar as consequência de uma redução do tônus colinérgico in vivo.

Corroborando o papel antiinflamatório do sistema colinérgico, Li et al. (2010) mostraram que a vagotomia cervical aumentou a expressão de TNFa, IL-6 e proteína do grupo de alta mobilidade 1 (HMGB1) detectados por ELISA ou por imunohistoquímica em modelo de artrite em camundongos. A estimulação elétrica do nervo vago eferente diminuiu a produção de citocinas pró-inflamatória em modelo experimental com endotoxemia letal (Huston et al., 2007), inibiu a resposta inflamatória aguda ao choque hipovolêmico agudo hemorrágico (Guarini et al., 2003) e diminui a inflamação intestinal induzida experimentalmente no íleo (Jonge, 2005). Além disso, Hofer et al., (2008) demonstraram que a inibição farmacológica da colinesterase com fisostigmina ou neostigmina aumentou a sobrevida de camundongos com sepsis experimental.

Utilizando ratos e camundongos com inflamação alérgica aguda de vias aéreas, Lips et al. (2007) demonstraram que houve redução da ChAT, ChT1 e VAChT no pulmão dos animais sensibilizados e desafiados com alérgeno, sugerindo que há uma redução na atividade do sistema colinérgico antiinflamatório nestes animais, o que poderia contribuir para o dano epitelial e as disfunções das células ciliadas observadas na asma brônquica. 


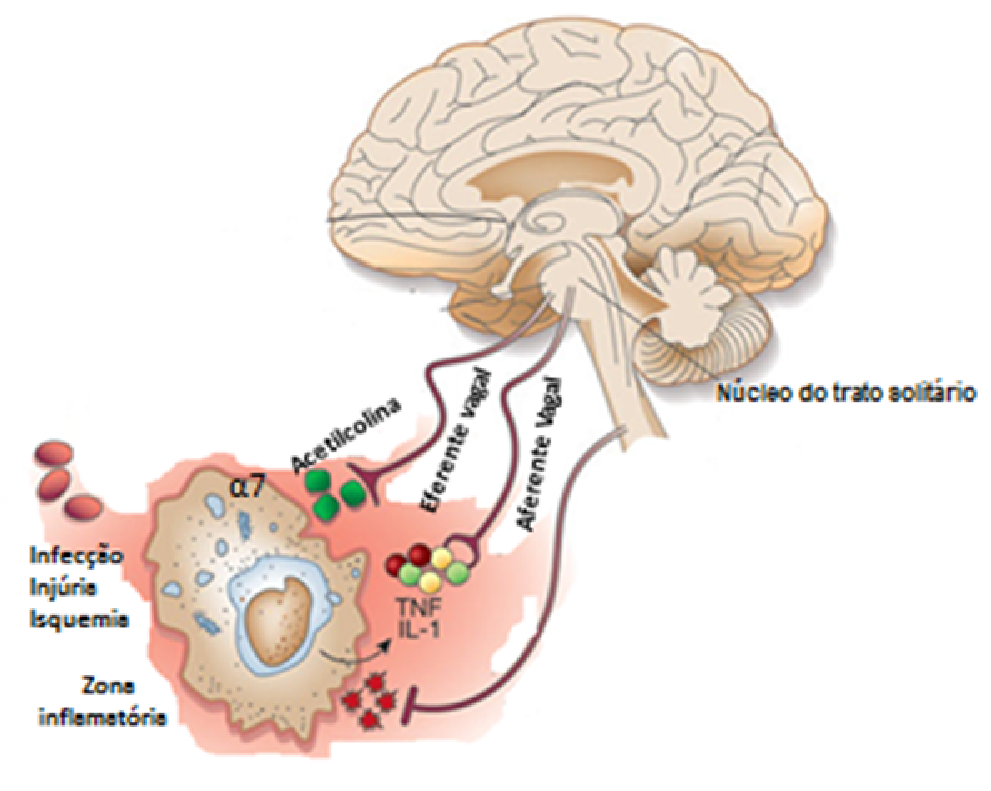

Tracey J. Kevin Nature 2002;420:853-859

Figura 4. Arco reflexo da inflamação - Citocinas liberadas no local da inflamação ativam fibras aferentes do nervo vago e chegam ao núcleo do trato solitário no tronco cerebral, proporcionando assim a informação do sistema nervoso autônomo em relação ao estado inflamatório periférico. Sinais de compensação são transmitidos pelo nervo vago eferente e chegam ao local da inflamação, onde a ACh age sobre os macrófagos e outras células do sistema imunológico para atenuar a resposta inflamatória. (Modificado de Tracey,2002)

Outros autores também sugerem que o sistema colinérgico exerce efeito protetor na inflamação pulmonar (Giebelen et al., 2007; Hofer et al., 2008; Li et al., 2010). Recentemente, Boland et al. (2011), estudando modelo experimental de lesão pulmonar aguda induzida por peritonite séptica, observaram que a estimulação elétrica do nervo vago, com .consequentemente aumento da liberação da ACh, reduziu o índice de lesão pulmonar e aumentou a sobrevida dos animais. 
Em contraste ao observado nos efeitos da acetilcolina nos receptores muscarínicos, o papel da acetilcolina em receptores nicotínicos parece ter efeito benéfico, sugerindo que seja esta a via envolvida no arco reflexo antiinflamatório. Os receptores nicotínicos (nAChRs) são do tipo canais iônicos regulados por ligantes e podem ser compostos pela combinação de 17 diferentes tipos de receptor (Gwilt et al.,2007). Nas vias aéreas, os receptores nicotínicos são encontrados em células nervosas, células epiteliais, macrófagos alveolares, e linfócitos T (Maus et al., 1998). Frente às descobertas incessantes de novas unidades e subunidades dos receptores nicotínicos expressos nas células das vias aéreas e no tecido pulmonar, as funções destes receptores são bastante complexas. Um resumo destas funções pode ser observado na Tabela 3.

Tabela 3. Receptores nicotínicos, as suas subunidade e função nas vias aéreas e células pulmonares.

\begin{tabular}{|c|c|c|}
\hline Evidência direta & Subunidades & Função \\
\hline $\begin{array}{c}\text { Células epiteliais } \\
\text { brônquicas }\end{array}$ & $\alpha 3, \alpha 5, \alpha 7, \beta 2, \beta 4$ & proliferação do cálcio \\
\hline $\begin{array}{c}\text { Células epiteliais } \\
\text { alveolares }\end{array}$ & $\alpha 3, \alpha 4, \alpha 5, \alpha 6, \alpha 7$ & $?$ \\
\hline $\begin{array}{c}\text { Glândulas submucosas } \\
\text { Musculatura lisa das } \\
\text { vias aéreas }\end{array}$ & $\alpha 7$ & Inibição da contração \\
\hline Células endoteliais & $\alpha 7$ & $?$ \\
\hline Fibroblastos & $\alpha 7$ & $\begin{array}{c}\text { ativação do fator de } \\
\text { crescimento e síntese } \\
\text { de colágeno }\end{array}$ \\
\hline Macrófagos alveolares & $\alpha 4, \alpha 7, \beta 2$ & $\begin{array}{c}\text { Inibição da liberação do } \\
\text { TNF- } \alpha\end{array}$ \\
\hline
\end{tabular}

Fonte: Modificado de Racké e Matthiesen,2004

Alguns autores já mostraram a expressão de receptores nicotínicos em células inflamatórias, como por exemplo, os eosinófilos (Blanchet et al., 2007). Vários mecanismos controlam o processo inflamatório e a ação da ACh em receptores nicotínicos, especialmente no $\alpha 7 \mathrm{nAChR}$ (do inglês, $\alpha 7$ 
nicotinic acetylcholine receptor, receptor nicotínico $\alpha 7$ de acetilcolina), tem amplo efeito no ajuste fino para restabelecer a homeostasia, pois inibe a produção de citocinas pró-inflamatórias, como o TNF- $\alpha$, HMGB-1 e IL-1 $\beta$ (Fodale, Santamaria ,2008).

O tratamento com nicotina também reduziu a incidência de diabetes tipo I em modelos animais (Mabley et al., 2002); teve um efeito antiinflamatório em modelos animais de inflamação do sistema nervoso central (Shi et al., 2009), artrite (Van Maanen et al., 2009), alergia/asma (Mishra et al., 2008), inflamação intestinal (The, et al., 2007) e peritonite (van Westerloo et al., 2005). Esses dados sugerem que a ativação da via colinérgica antiinflamatória por administração de agonista colinérgico nicotínico contribui para o controle do processo inflamatório.

Rosas- Ballinas (2009) estudando células sanguínea de humanos, observaram que o agonista seletivo para o $\alpha 7$, GTS21, reduziu os níveis de TNF- $\alpha$ e IL-1 $\beta$ liberadas pelas células após estímulo por endotoxina. Além disso, a estimulação de receptores nicotínicos atenuou a inflamação sistêmica e aumentou a sobrevida de camundongos com sepse abdominal polimicrobiana (Barnes et al., 2004) e reduziu a liberação de citocinas próinflamatórias durante peritonite Escherichia coli (Van Westerloo et al., 2005).

No pulmão, Mabley et al. (2011) demonstraram camundongos que receberam instilação intratraqueal de lipopolissacarídeos (LPS) tiveram redução das células inflamatórias no LBA, das quimiocinas pró-inflamatória (MIP-1a, MIP-2, e eotaxina) e das citocinas pró-inflamatória (IL-1, IL-6 e TNF- $\alpha$ ) após o tratamento com agonista colinérgico (nicotina). Blanchet et al (2005) mostrou, utilizando modelo experimental de asma, que o uso de agonistas nicotínicos não seletivo reduz o influxo total de células inflamatórias e a eosinofilia pulmonar. Esses dados contribuem para que a ativação de receptores nicotínicos seja considerada como um novo alvo terapêutico na síndrome da angústia respiratória aguda. 
Diversos estudos utilizando agonistas ou antagonistas específicos sugerem que o $\alpha 7-n A C h R$ seja o mais envolvido na controle da resposta inflamatória. Giebelen et al. (2007) observaram que administração local de GTS-21, um agonista seletivo do receptor colinérgico $\alpha 7$, inibiu a liberação pulmonar de TNF-a em camundongos com inflamação pulmonar induzida por instilação de LPS (Lipopolissacarídeo). Su et al. (2010) testaram o potencial terapêutico do receptor nicotínico para acetilcolina $\alpha 7$ ( $\alpha 7-n A C h R)$. Neste estudo foi abordado a contribuição do $\alpha 7-n A C h R$ na mediação da lesão pulmonar induzida por Escherichia coli em camundongos. Os autores observaram que a administração do agonista do receptor $\alpha 7-n A C h R$, diminuiu os níveis de MIP-2 no LBA, assim como a mortalidade. Por outro lado, a vagotomia aumentou a produção de MIP-2, o infiltrado de neutrófilos nas vias aéreas e a mortalidade. Os autores ainda demonstraram que, animais Knockout para a7-nAChR desenvolveram lesão pulmonar grave e tiveram maior mortalidade quando comparados ao grupo sem modificação genética.

Atualmente muitas pesquisas estão voltadas para explicar quais os mecanismos envolvidos no controle da inflamação pelos nAChR $\alpha 7 \mathrm{em}$ células do sistema imunológico. Duas vias principais têm sido recentemente relatadas nas células do sistema imune. Durante a infecção ou trauma, componentes bacterianos como o LPS ou proteínas de ligação como a CD14 e a TLR4, desencadeiam circuito pró-inflamatório e convergem o fator de transcrição NF-kB a se translocar para o núcleo, onde liberam uma variedade de citocinas inflamatórias como TNF-a e HMGB1 (Wang et al., 2004; Yoshikawa et al., 2006 ). As citocinas TNF-a e HMGB1, via o arco reflexo da inflamação, estimulam o nervo vago a liberar acetilcolina que interage principalmente com o $\alpha 7 \mathrm{nAChR}$ e inibe a translocação do NF-kB para o núcleo, inibindo assim a sua cascata inflamatória. Outra hipótese é que a ativação do $\alpha 7$ recrute a tirosina quinase (JAK2) e promove a fosforilação e ativação subsequente de STAT3 (do inglês signal transducer and activator of transcription). A via Jak2-STAT3 é coadjuvante para o 
potencial anti-inflamatório do sistema colinérgico, pois induz a expressão de proteínas anti-inflamatórias (Figura 5).

Apesar de diversas evidências sugiram que o efeito antiinflamatorio da ACh seja via receptores nicotínicos, alguns estudos ainda mostraram que, embora a presença de receptores muscarínicos em órgãos periféricos não seja necessária para o controle da inflamação via nervo vago, a ativação de receptores muscarínicos no sistema nervoso central é importante na atenuação da resposta inflamatória. Neste sentido, a administração intracerebroventricular de muscarina ou de agonistas de receptores muscarínicos M1 atenuou os níveis de TNF- $\alpha$ em modelo murino de endotoxemia (Pavlov et al., 2006).

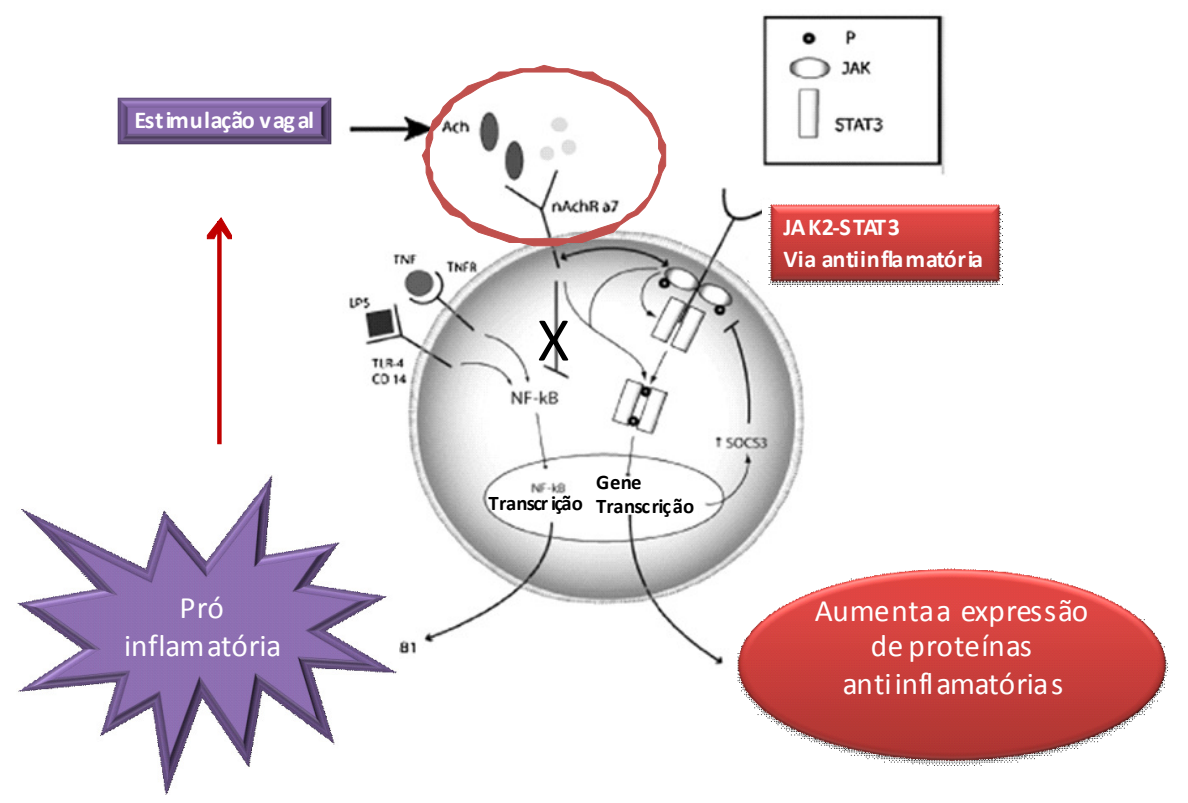

Figura 5. Hipóteses dos mecanismos envolvidos na resposta colinérgica anti-inflamatória (Adaptado de Gallowitsch-Puerta, Tracey, 2005). 
Em conjunto, estes resultados acima descritos, sugerem que 0 sistema colinérgico anti-inflamatório, que coloca no ápice a ACh para o controle da resposta inflamatória do sistema nervoso central e periférico, pode ser uma nova estratégia terapêutica a ser estudada em diversas situações patológicas. No pulmão, o efeito da ACh é amplo e imbricado com as células do sistema imune, com as unidades e subunidades dos receptores muscarínicos e nicotínicos e com o sistema nervoso central.

\subsection{MODELO DE ASMA EXPERIMENTAL}

O desenvolvimento de modelos experimentais utilizando distintas linhagens, inclusive animais transgênicos, tem sido uma importante ferramenta para dissecar os diferentes mecanismos imunológicos envolvidos nas doenças pulmonares.

Durante muitos anos o modelo experimental de asma vem sendo desenvolvido em uma variedade de espécie. A cobaia, que possui como órgão choque o pulmão, é o modelo que mais desenvolve características da asma humana devido à fácil indução da resposta alergênica com ovalbumina (Smith et al., 2007). Porém, devido ao alto custo, disponibilidade maior de espaço e principalmente a indisponibilidade de anticorpos comerciais para elucidar mecanismos celulares e moleculares e a dificuldade de se fazerem modificações genéticas, os camundongos vem sendo atualmente mais utilizados.

Os murinos oferecem uma gama vasta de possibilidades refinadas para a pesquisa, além do mapa genético e a informação imunológica destes animais estarem disponíveis. Além disso, é possível trabalhar alterando ou suprimindo os produtos de genes, relevantes ou de particular interesse para demonstrar a validade de um alvo molecular ou para explorar a importância 
de um único mediador (Tournoy et al., 2006, Hellings et al., 2004)

Neste sentido, Gueders et al. (2009), questionaram se a base genética dos animais experimentais poderiam afetar a hiperresponsividade, inflamação e produção de citocinas. Para responder a esta pergunta compararam as linhagens BALB/C e C57BL/6. Além das diferenças específicas na distribuição do perfil de citocinas pró-inflamatórias, animais da linhagem BALB/c apresentaram maior hiper-reatividade à metacolina e maior número de mastócitos no tecido pulmonar, enquanto os animais da linhagem C57BL/6 apresentaram maior contagem de eosinófilos e neutrófilo no LBA.

O modelo de injeções intraperitoneais da proteína ovoalbumina (OVA) juntamente com o adjuvante hidróxido de alumínio é o mais utilizado em função da facilidade para indução alérgica e da excelente resposta pulmonar (Kuma et al.,2008). Contudo, recentemente, Conrad et al (2009) utilizando animais BalB-C e C57BL6, compararam a sensibilização com injeção intraperitoneal de OVA com adjuvante (hidróxido de alumínio) com a indução da sensibilização via subcutâneos sem adjuvante. Os autores mostraram que não houveram modificações importantes para o fenótipo da asma no que se refere à inflamação do pulmão, contagem de células no LBA, reatividade das vias aéreas e expressão inflamatória das citocinas, considerando as diferentes vias de indução da inflamação. Além disso, mostraram que animais da linhagem BALBc, que receberam sensibilização associada ao uso de adjuvante, tiveram aumento do estresse que iniciou 15 minutos após a injeção e normalizou somente 120 minutos após. Assim, sugerem que não há necessidade da utilização de alumen para a indução alérgica crônica. Corroborando com estes dados Goplen et al. (2009) mostraram que a exposição a múltiplos antígenos produz inflamação na ausência de adjuvante (Jason HT et al., 2008 e Carmen A,1999). No entanto, a administração de adjuvante ainda é bastante utilizada.

De forma geral, os modelos animais acima citados mimetizam diversas características da asma humana, oferecendo uma forma de se 
avaliar mecanismos imunológicos da inflamação, a interação do sistema imune inato e adaptativo, que desempenham papéis fundamentais na regulação do processo inflamatório local. Por fim, cabe ressaltar que estes modelos oferecem essencialmente uma análise aprimorada in vivo.

\subsection{JUSTIFICATIVA PARA O ESTUDO}

É reconhecido que a ACh é um mediador de fundamental importância na modulação da constrição da musculatura lisa que ocorre na asma e no DPOC. Esta é a base para o uso da terapia anticolinérgica na asma e doença pulmonar obstrutiva crônica (DPOC). A importância fisiopatológica do sistema colinérgico anti-inflamatório foi recentemente descrita em outros modelos experimentais de doenças cerebrovasculares, musculares, cardíacos, entre outras.

Considerando que poucos estudos avaliaram os efeitos do sistema colinérgico anti-inflamatório na inflamação pulmonar, os efeitos da ACh em situações fisiopatológicas pulmonares ainda são controversos, podendo esta contribuir ou suprimir a resposta inflamatória, provavelmente dependendo do tipo de receptor em que atua.

Desta forma, a ACh não pode ser considerada exclusivamente como um neurotransmissor do sistema nervoso parassimpático, mas sim reconhecida como um componente integral da defesa e regulador da inflamação de vias aéreas. A redução na função do sistema colinérgico pode ter um efeito pró-inflamatório ao invés de antiinflamatório.

Assim, consideramos de relevância esclarecer os múltiplos papéis biológicos da acetilcolina, identificando a repercussão morfofuncional do aumento e/ou diminuição da ativação deste sistema particularmente na 
asma brônquica, doença que ainda afeta grande número de pacientes. Estes esclarecimentos podem contribuir com novos alvos terapêuticos e preventivos que modulem o sistema colinérgico, além de um melhor entendimento de mecanismos fisiopatológicos.

O distúrbio genético da neurotransmissão colinérgica em modelos animais é complexo (Castro et al., 2009) devido a liberação de ACh ser necessária para a função de múltiplos órgãos. Considerando a abundância dos receptores da $\mathrm{ACh}$, estudos de receptores individuais podem não revelar as consequência de uma redução do tônus colinérgico in vivo. O uso de animais transgênicos com alteração ou deleção de genes específicos é de grande interesse para demonstrar a importância de um único mediador. Assim, considerando a deficiência colinérgica a longo prazo, este estudo é inovador e permitiu compreender os efeitos da deficiência colinérgica na fisiopatologia da asma, abrindo novas frentes de investigação.

Julgamos assim que, este tipo de protocolo, embora com algumas limitações, permita que as interações de diversos órgãos e sistemas possam ser avaliadas. 
O objetivo do presente estudo foi:

Avaliar os efeitos da deficiência colinérgica por redução da proteína transportadora vesicular da acetilcolina (VAChT) em modelo experimental de inflamação pulmonar induzida pela exposição repetida a ovoalbumina, particularmente no que se refere a:

a-Hiperresponsividade brônquica

b- Inflamação de vias aéreas e citocinas pulmonares

C- Remodelamento de vias aéreas e expressão de metaloproteinase-9 e TIMP-1 


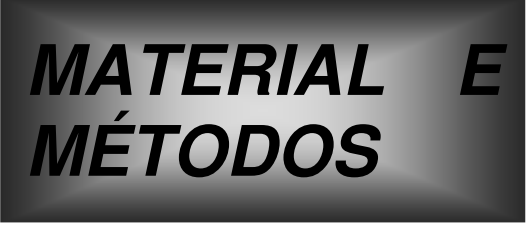


Este estudo foi aprovado pela Comissão de Ética para Análise de Projetos de Pesquisa (CAPPesq) do Hospital das Clínicas da Faculdade de Medicina da Universidade de São Paulo, sob o protocolo número 0766/08. Este trabalho foi desenvolvido no Laboratório de Terapêutica Experimental I (LIM-20) da Faculdade de Medicina da Universidade de São Paulo.

\subsection{Animais}

Foram utilizados camundongos geneticamente modificados para uma menor expressão (Knockdown) da proteína transportadora vesicular de acetilcolina KD-(VAChT). Estes animais foram retrocruzados por três gerações, tendo como base genética a linhagem C57BL/6 e foram gerados pela segmentação 5 UTR do gene VAChT por recombinação homóloga em fundo misto. Foram desenvolvidos e procriados pelo grupo do Professor Marco Antônio M. Prado na Universidade Federal de Minas Gerais (UFMG) e a partir deste estudo tem sido procriados por nosso grupo de pesquisa no Biotério Central da Faculdade de Medicina da Universidade de São Paulo.

Estes animais foram mantidos em heterozigose e acasalados quando necessário para gerar animais homozigotos e selvagem. Sequencialmente todos os animais foram submetidos à genotipagem para identificação, de acordo com a descrição feita por Prado et al., 2006a. Esta técnica foi realizada no Biotério Central desta Universidade e acompanhada por nosso grupo. Os animais homozigotos apresentam redução da expressão de acetilcolina na ordem de $70 \%$, o que leva a redução da liberação de acetilcolina na mesma ordem.

Todos os animais receberam cuidados de acordo com o Guia de Cuidados e uso de Animais de Laboratório, publicado pelo National Institute of Health (NIH publication 85-23, revisado em 1985), sendo que todos os 
procedimentos cirúrgicos foram realizados com os animais sob efeito de anestesia geral.

Para este estudo foram utilizados 54 animais dos grupos homozigoto (HOM) e selvagem (sem modificação genética - WT, de wild type), do sexo masculino, com idade aproximada de 6-8 semanas

\subsection{Grupos Experimentais}

Animais homozigotos e selvagem foram separados nos seguintes grupos experimentais:

A. Animais homozigotos submetidos á sensibilização e inalações com ovoalbumina (grupo HOM-OVA, $n=14$ );

B. Animais homozigotos submetidos á injeção subcutânea e inalações com soro fisiológico (grupo HOM-SAL, $n=14$ );

C. Animais selvagem submetidos à sensibilização e inalações ovoalbumina (OVA) (WT-OVA, $n=14)$;

D. Animais selvagem submetidos à injeção sucbcutâneal e inalações com soro fisiológico (grupo WT-SAL, n=9).

\subsection{Indução da inflamação pulmonar alérgica crônica}

A indução da inflamação pulmonar foi realizada, segundo protocolo previamente descrito por Conrad et al. (2009). Este protocolo preconiza o uso de injeções subcutâneas de OVA diluídas em solução fisiológica ( $\mathrm{NaCl}$ $0,9 \%$ ). 
Os animais com suas genotipagem previamente definidas iniciaram o protocolo de sensibilização que ao todo constava de 29 dias (Figura 6), sendo que nos dias 0,7 e 14 os animais foram sensibilizados com injeção

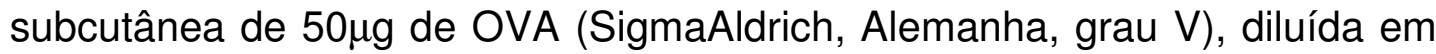
solução fisiológica de $200 \mathrm{ml}(\mathrm{NaCl}$ 0,9\%), sendo aplicado um volume de $0,2 \mathrm{ml}$ no dorso de cada animal, onde era observado o formato de uma bolha que correspondia ao fluído injetado sob a pele do animal. Nos animais controle (WT-SAL e HOM-SAL), foram realizadas injeções simuladas do veículo (solução salina) em protocolo idêntico.

Nos dias 26, 27 e 28, os animais foram colocados, em uma caixa de acrílico $(30 \times 15 \times 20 \mathrm{~cm})$ acoplada a um nebulizador ultrasônico (US - 1000, ICEL, São Paulo, Brasil) e submetidos a desafios com inalações de OVA na concentração de $10 \mathrm{mg} / \mathrm{ml}(1 \%)$ por 20 minutos. Animais dos grupos controle (WT-SAL e HOM-SAL), receberam solução salina ( $\mathrm{NaCl}$ $0,9 \%)$ em protocolo idêntico ao descrito acima.

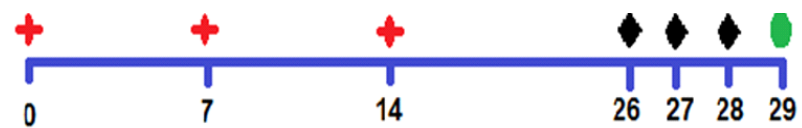

Injeção-Subcutânea de Salina ou $50 \mu \mathrm{g}$ OVA

Inalaçäo Salina ou OVA 1\% (20 min)

Mecânica Pulmonar e Avaliação histopatológica

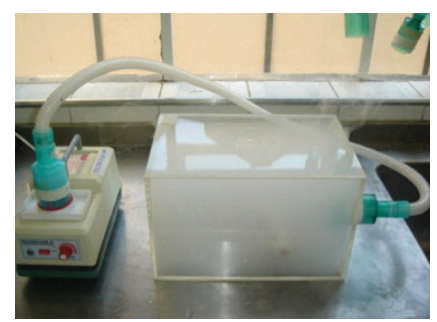

Figura 6. Esquema do protocolo de sensibilização. Animais homozigotos e selvagens foram sensibilizados nos dias 0,7 e $14 \mathrm{com}$ injeção subcutânea de OVA diluída em soro fisiológica $(50 \mu \mathrm{g})$ e submetidos a inalações de OVA a 1\% ou salina nos dias 26, 27 e 28. Após 24 horas do último desafio antigênico, todos os grupos experimentais foram anestesiados e submetidos a avaliação da mecânica pulmonar. 


\subsection{Avaliação da Mecânica do Sistema Respiratório}

Vinte e quatro horas após o último desafio antigênico, o que corresponde ao dia 29 do protocolo experimental (Figura 6), os animais foram pesados, anestesiados (tiopental $80 \mathrm{mg} / \mathrm{kg}$ ), traqueostomizados e conectados a um ventilador mecânico próprio para animais de pequeno porte (FlexiVent, SCIREQ, Montreal, Canada), ventilados com volume corrente de $10 \mathrm{~mL} / \mathrm{Kg}$ e frequência respiratória de 150ciclos/min (Figura 7). Imediatamente iniciou-se a cateterização da veia jugular direita com cateter de polietileno (Intramedic, Batavia). Iniciou-se a curva dose resposta ao agonista broncoconstritor metacolina, que foi infudido intravenoso, nas doses de 10-3000 ug. $\mathrm{mL}^{-1}$

Os dados de Rrs (Resistência) e Ers (Elastância) foram coletados no momento basal (após a infusão de soro fisiológico) e após 30 segundos da infusão de cada dose. Foi dado um intervalo de 2 minutos entre cada dose. Ainda sob efeito da anestesia, os animais foram submetidos à laparotomia e a exsanguinação foi realizada por secção da artéria aorta abdomina

Foi calculada a impedância do sistema respiratório (Zrs) dos animais de cada grupo e utilizado um volume de perturbação de 16 segundos. A ventilação mecânica foi parada somente para a aplicação das perturbações. Para o cálculo dos dados foram feitas correções, considerando as perdas devido à compressibilidade dos gases (Bates et al., 2003). Vcyl foi corrigido a fim de obter 0 volume que efetivamente chegou ao animal (V) e $P$ cyl foi corrigido, nos dando o valor de Pao, pressão de abertura das vias aéreas. Através da derivação no tempo de $\mathrm{V}$, obtivemos o valor do fluxo (V'). 
Entre o ventilador e o animal havia um transdutor de pressão (Figura 7) onde foram coletados os sinais de pressão e fluxo que foram registrados e enviados a um microcomputador que realizava o cálculo da elastância total do sistema respiratório (Ers) e da resistência do sistema respiratório (Rrs) utilizando a equação do movimento do sistema respiratório:

$$
\operatorname{Ptr}(\mathrm{t})=\mathrm{Ers} \cdot \mathrm{V}(\mathrm{t})+\operatorname{Rrs} \cdot \mathrm{V}^{\prime}(\mathrm{t})
$$

onde: Ptr é a pressão traqueal, $V$ é o volume, $V^{\prime}$ é o fluxo e $t$ corresponde ao tempo.
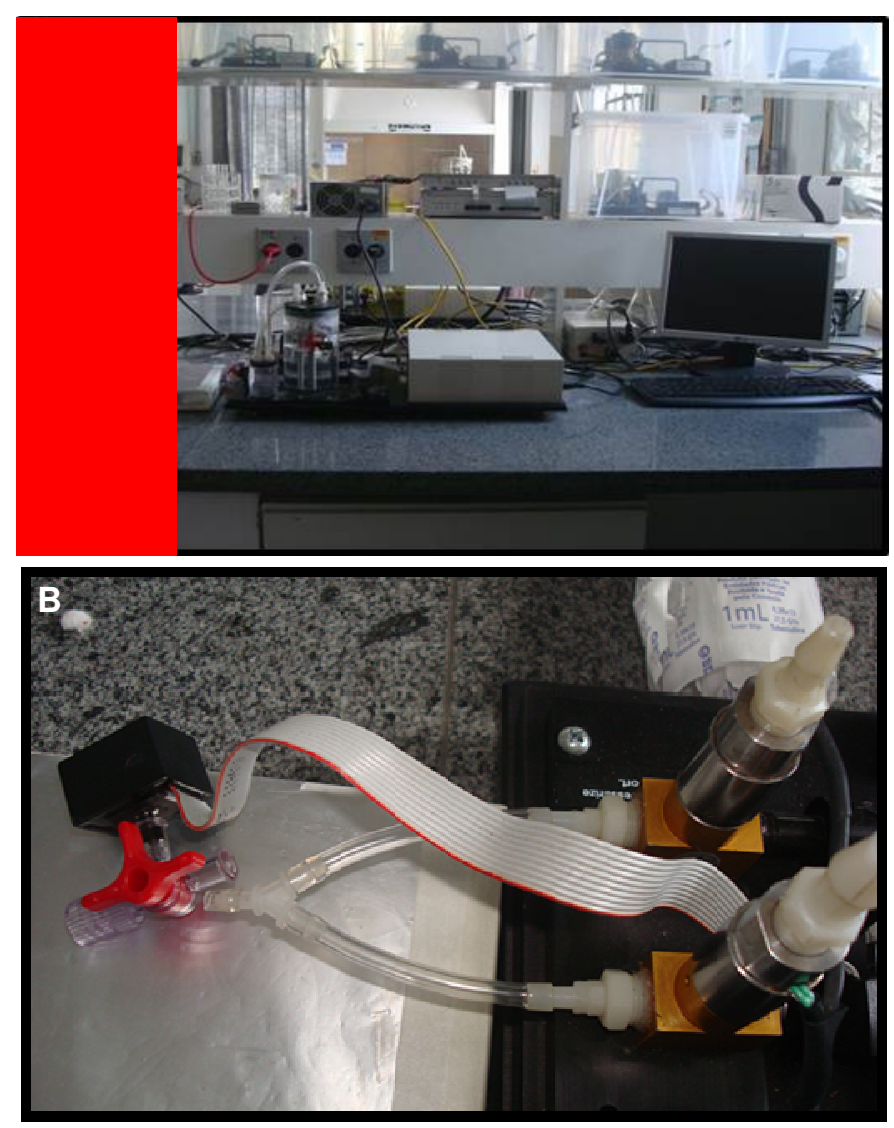

Figura 7. Aparato experimental. A.Equipamento necessário para avaliação da mecânica pulmonar (FlexiVent, SCIREQ, Montreal, Canada). B. Foto do transdutor de pressão. Este equipamento capta as variações de pressão e fluxo e envia ao computador (Painel A) que, através da equação do movimento respiratório, calcula os valores de resistência e elastância do sistema respiratório. 
Os dados de Rrs e Ers foram coletados no momento basal (após a infusão de soro fisiológico) e após 30 segundos da infusão de cada dose. Foi dado um intervalo de 2 minutos entre cada dose. Ainda sob efeito da anestesia, os animais foram submetidos à laparotomia e a exsanguinação foi realizada por secção da artéria aorta abdominal

\subsection{Lavado Bronco-Alveolar (LBA):}

Imediatamente após a exsanguinação, foi coletado o lavado broncoalveolar (LBA) por meio da infusão de 0,5 mL de PBS (tampão fosfato salina) por 3 vezes consecutivas (total volume 1,5mL) na cânula traqueal, com 0 uso de uma seringa. O volume recuperado via cânula traqueal foi centrifugado a $1000 \mathrm{rpm}$, a $5^{\circ} \mathrm{C}$, por $10 \mathrm{~min}$. O botão celular foi ressuspendido em $200 \mu \mathrm{L}$ de PBS. A contagem total de células foi realizada por microscopia ótica com o auxilio de um hemocitômetro de Neubauer no aumento de 400x.

Para a contagem diferencial, $100 \mu \mathrm{L}$ do LBA foram citocentrifugados a 450 rpm por 6 minutos (Cytospin, Cheshire, UK) e após seca a lâmina, esta foi corada pela técnica de Diff-Quick (Biochemical Sciences INC, Swedesboro, NJ). A contagem diferencial das células foi determinada a partir do achado de pelo menos 300 leucócitos/lâmina e a diferenciação seguiu os critérios hemocitológicos para diferenciação de neutrófilos, eosinófilos, linfócitos e macrófagos com o auxílio de um microscópio óptico com objetiva de imersão (aumento de 1000X). Os resultados estão expressos em células por $m L$ de LBA. 


\subsection{Estudo Morfométrico}

Imediatamente após a coleta do LBA, os pulmões foram insuflados com formol a $10 \%$ em volume equivalente ao volume corrente de cada animal $(10 \mathrm{~mL} / \mathrm{Kg})$ e pulmão e coração foram retirados em monobloco. Os pulmões foram fixados em formol a $4 \%$ por 24 horas. Após este período, os pulmões foram transferidos para etanol $70 \%$ e submetido às técnicas histológicas habituais com parafina, para obtenção de cortes de $4 \mu \mathrm{m}$ de espessura.

\subsubsection{Avaliação do Edema Peribrônquico e Células} Inflamatórias ao redor das Vias Aéreas. A coloração de Hematoxilina e Eosina foi utilizada para avaliação do edema peribroncovascular e para quantificação das de células inflamatórias (mononucleares e polimorfonucleares) ao redor das vias aéreas. As quantificações foram realizadas pela técnica de contagem de pontos e retas (Weibel et al., 1963), por meio de um microscópio óptico (CH30, Olympus, Japão) e com o auxílio de um retículo de 100 pontos e 50 retas com área conhecida em um aumento de 1000x (Figura 8).

O retículo foi ancorado na base do epitélio, sendo que a quantificação do número de células positivas foi dada pela razão entre o número de células em determinada área e o número de pontos que coincide com a área peribrônquica, entre o epitélio e a adventícia. Os resultados do edema peribrônquico foram expressos em área de edema $(\mu \mathrm{m} 2)$ e os resultados das células foram expressas em célula por unidade de área $\left(10^{4} \mu \mathrm{m}^{2}\right.$ ) (Prado et al., 2006b). Para todas as análises foram avaliados de 16 campos de 4 vias aéreas randomicamente selecionados por corte. 


\subsubsection{Avaliação do Remodelamento Brônquico:}

A coloração de Sirius-Red (Direct Red 80, Cl 35780, Aldrich, EUA) foi utilizada para a contagem das fibras colágenas na parede das vias aéreas. Os cortes foram desparafinados e lavados com água. Além disso, foram corados por 1 hora no Picro-Sírius Red (Direct Red 80, C. I. 35780, Aldrich, Milwaukee, WI, EUA) à temperatura ambiente e posteriormente lavados em água corrente por 5 minutos. Após esta etapa, os cortes foram corados pela Hematoxilina de Harris por 6 minutos e posteriormente lavados em água corrente por 10 minutos. Por fim, as lâminas foram montadas (Prado et al., 2006b)

A coloração de Resorcina-Fucsina Oxidada foi utilizada para avaliação das fibras elásticas (propriamente dita, eulanínicas e oxitalânicas) ao redor das vias aéreas. Para tanto, os cortes foram desparafinados e hidratados em água. Sobre eles, foi gotejada uma solução aquosa de OXONA $10 \%$ e ficaram oxidando por 40 minutos. Foram então lavados em água corrente por 5 minutos e após serão submersos no álcool $70^{\circ}$ e $95^{\circ}$. Após as lâminas foram coradas com Resorcina-Fucsina (Angeli et al., 2008).

A quantificação de fibras colágenas e elásticas no pulmão foi realizada no analisador de imagens (Image ProPlus 4.5.029 for Windows 98/NT/2000), onde a medida de densidade óptica é o método empregado para detecção das fibras. As imagens foram capturadas (aumento de 400x) por uma câmera modelo DFC420 (Leica, Wetzlar, Alemanha) acoplada a um microscópio óptico trinocular DM2500 (Leica), e enviadas ao computador onde foram processadas pelo programa Qwin Plus (Leica). Após a captura das imagens, para cada coloração, um filtro de cores pré-montado com base em um número representativo de fotos de todos os grupos experimentais foi determinado. Este filtro foi aplicado em todas as leituras de todos os grupos experimentais. Manualmente a área da parede das vias aéreas foi determinada (Figura 8B) e os resultados foram expressos em porcentagem de área de fibras positivas (Colágenas ou Elásticas) em relação à área total 
da parede da via aérea (Prado et al., 2005, 2006b).

Toda a análise morfométrica foi realizada por dois pesquisadores que não tinham conhecimento do grupo experimental a que pertencia as lâminas.
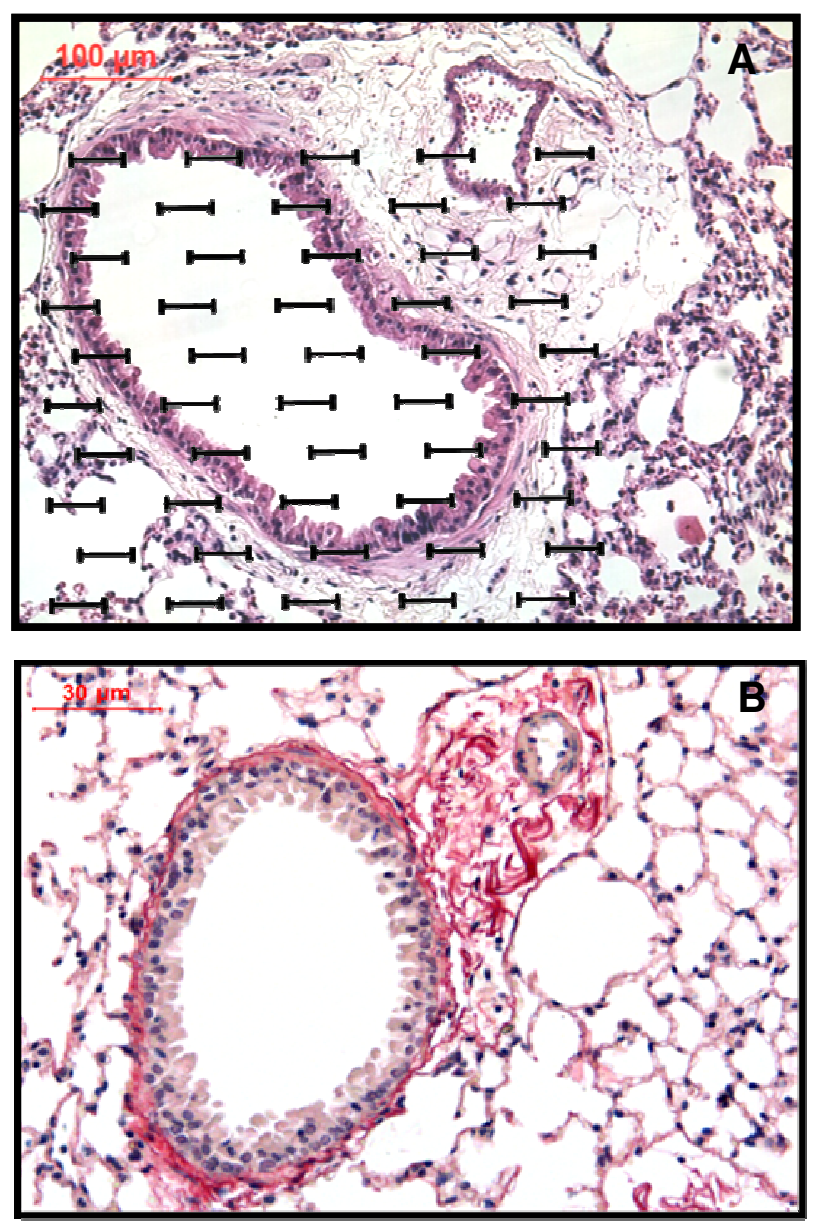

Figura 8. Análise Morfométrica. A. Um retículo composto de 50 retas e 100 pontos foi acoplado a ocular do microscopio. Foram quantificadas as células mononucleares ou polimorfonucleares na área determinada (entre a adventícia e a base do epitélio) e o número de pontos que coincidia com esta região. O número de células inflamatórias é dado pela razão entre o número de células contadas e o número de pontos e expresso em célula por área. B. .Análise de Imagem para leitura de fibras colágenas e elásticas na parede das vias aéreas. Para tanto, as imagens das lâminas coradas com Picro-Sírius ou Resorcina Fucsina Oxidada foram capturadas por uma câmara acoplada a um microscópio e enviadas para um computador. Posteriormente se determina a área de interesse (no caso as fibras elásticas e colágenas) por um degrade de cores. 


\subsubsection{Imunohistoquímica para detecção de células positivas para IL-4, MMP-9 e TIMP-1}

A imuno-histoquímica para pesquisa dos anticorpos anti-IL-4, anti-IL13, anti-MMP-9 e anti-TIMP-1 foi realizada pelo método Biotinaestreptavidina peroxidase. Para tanto, as lâminas foram desparafinizadas, seguindo do processo de hidratação. A recuperação antigênica foi obtida através de citrato PH 6.0 alta temperatura seguida de lavagem com PBS. O bloqueio da peroxidade endógena foi realizado com água oxigenada (H2O2)10V 3\%. Após, iniciou-se a etapa de incubação com os anticorpos. Foram utilizados os anticorpos primários anti-IL-4, anti-IL-10, anti-IL-13, antiMMP-9 (1:600) e TIMP-1 (1:100) (Santa Cruz Biotechnology, Santa Cruz, CA). As lâminas foram incubadas "overnight". Após foram lavadas e montadas. O número de células positivas para estas colorações foram avaliadas pela técnica de contagem de pontos e retas, como descrito no item 3.6.1. Os resultados foram expressos células positivas/área $\left(10^{4} \mathrm{um}^{2}\right)$.

\subsection{Análise de Citocinas no Homogenato Pulmonar}

Em outro grupo de animais (5 por grupo), no dia 29 do protocolo experimental, os animais foram anestesiados, exanguinados da mesma forma descrita acima e os pulmões foram removidos e congelados rapidamente para realizar dosagem de citocinas em homogenato de pulmão por ELISA. A produção de IL-4, IL-10 foi realizado pelo BioPlex. Os níveis de TNF-a foi capturada pelo método de imunoensaio enzimático (ELISA). Os pulmões foram macerados e a dosagem foi realizada no homogenato de pulmão, os valores estão expressos por quantidade da citocina de interesse em pg por $\mu \mathrm{g}$ de proteína total. As amostras foram testadas em duplicata e 
uma curva padrão foi realizada em cada placa. Os testes foram realizados de acordo com as instruções do fabricante e só foram considerados valores que estavam dentro da curva.

\subsection{Análise Estatística:}

Para a análise estatística foi utilizado o software Sigma Stat (Jandel Scientific, San Rafael, CA). Os dados foram avaliados por análise de variância dois fatores e as comparações múltiplas foram feitas através de Student-Newman-Keuls. Os dados foram apresentados em forma de média \pm erro padrão e os gráficos em forma de barras paralelas. Foi considerado estatisticamente significativo o $p<0,05$. 


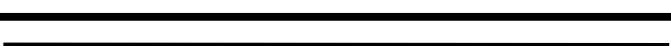




\subsection{Avaliação da Mecânica Respiratória}

$\mathrm{Na}$ FIGURA 9 pode-se observar os valores da porcentagem da resposta máxima de resistência (\%Rrs) (Painel A) e elastância (\%Ers) (Painel B) do sistema respiratório em relação ao basal. Não houve diferença na \%Rrs e \%Ers entre os animais que foram submetidos ao protocolo de salina (WT-SAL e HOM-SAL). Ao observamos o efeitos da sensibilização nos animais estudados, notamos que os grupos sensibilizados com OVA

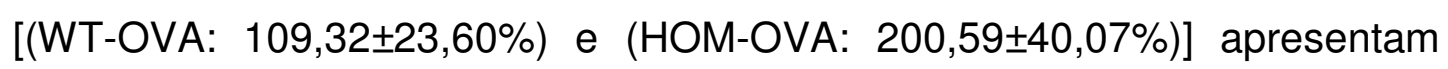
maior \%Rrs quando comparado aos respectivos controles que receberam

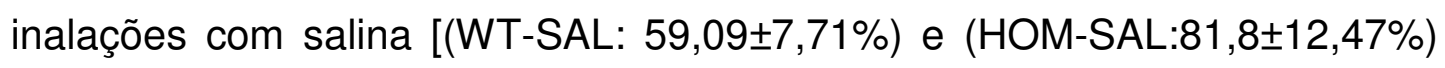
$(P<0,01)$. A deficiência colinérgica nos animais submetidos ao protocolo de OVA (grupo HOM-OVA) induziu um aumento na \%Rrs em relação ao grupo WT-OVA $(\mathrm{P}<0,05)$.

Avaliando a \%Ers, não foram encontradas diferenças significativas em nenhum dos grupos estudados [(WT-SAL: 53,62 $\pm 1,88 \%$ ), (HOM-SAL:

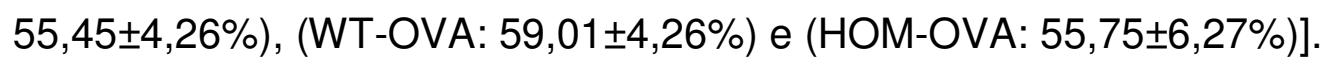



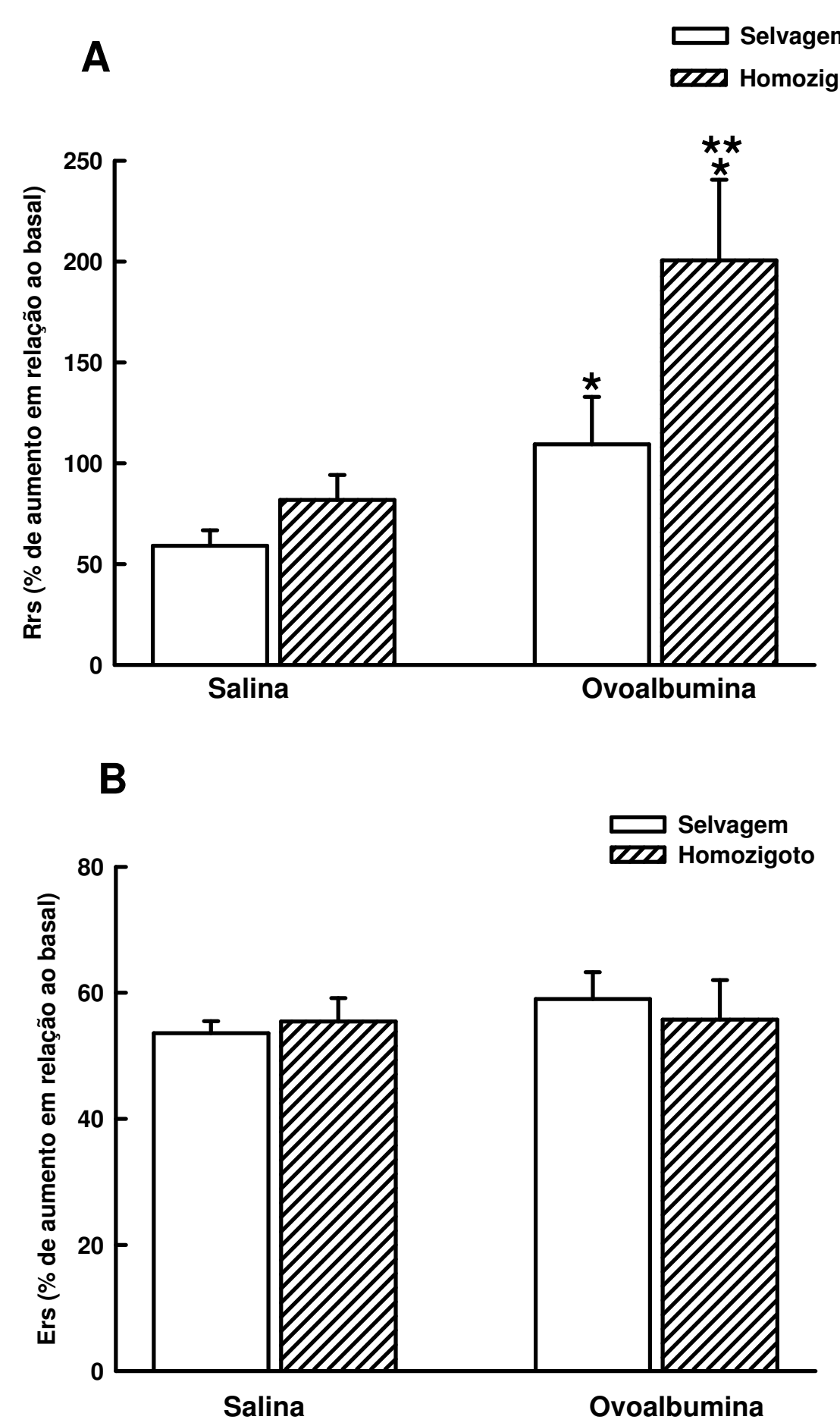

Figura 9: Média e erro padrão dos valores de porcentagem de aumento máxima em relação ao basal de resistência (Rrs) (Painel A) e elastância (Painel B) do sistema respiratório dos quatro grupos estudados. ${ }^{*} \mathrm{P}<0,01$ comparados aos grupos Salinas, respectivamente; ${ }^{* *} \mathrm{P}<0,05$ comparado ao grupo selvagem-ovoalbumina (WT-OVA). 


\subsection{Lavado BroncoAlveolar (LBA)}

$\mathrm{Na}$ Figura 10, pode-se observar os valores de células totais (Figura 10A) e do diferencial celular (Figura $10 \mathrm{~B}$ a E) quantificados no LBA dos quatro grupos estudados. Não houve diferença estatisticamente significativa nos grupos que foram submetidos ao protocolo com salina. Os animais sensibilizados apresentaram aumento de células totais [(WT-OVA:

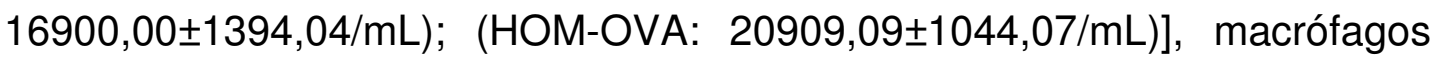
[(WT-OVA: $15559,00 \pm 1333,89 / \mathrm{mL}) ; \quad(H O M-O V A: 17638,00 \pm 1049,56 / \mathrm{mL})]$,

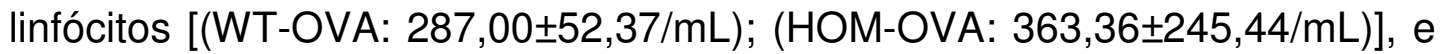
eosinófilos [(WT-OVA: 1013,70 $\pm 230,15 / \mathrm{mL})$; (HOM-OVA: $1496,92 \pm 210,69 / \mathrm{mL})]$, em relação aos animais dos grupos que receberam inalações com salina [WT-SAL: (células totais: 5937,50 $\pm 988,49 / \mathrm{mL}$ ), (macrófagos: $5770,37 \pm 1047,79 / \mathrm{mL}$ ); (Linfócitos: 29,26 $\pm 8,32 / \mathrm{mL}$ ), (eosinófilos: 21,04 $\pm 9,88 / \mathrm{mL}$ ) e HOM-SAL (células totais: 9125,0 $\pm 1044,07 / \mathrm{mL}$ ), (macrófagos: 6396,46 $\pm 1599,26 / \mathrm{mL}$ ); (Linfócitos: $83,37 \pm 30,78 / \mathrm{mL}$ ), (eosinófilos: $69,724 \pm 23,36 / \mathrm{mL}) \quad(P \leq 0,001$ para todas as comparações).

Os animais com deficiência colinérgica submetidos à sensibilização com OVA (HOM-OVA) apresentaram ainda maior número de células totais e de eosinófilos comparativamente aqueles obtidos nos animais selvagem que também foram submetidos a inalações com ovoalbumina (WT-OVA) $(P<0,05)$. Não houve efeito significativo da deficiência colinérgica em linfócitos e macrófagos.

Não houve diferença na quantificação de neutrófilos em nenhum dos grupos experimentais estudados. 

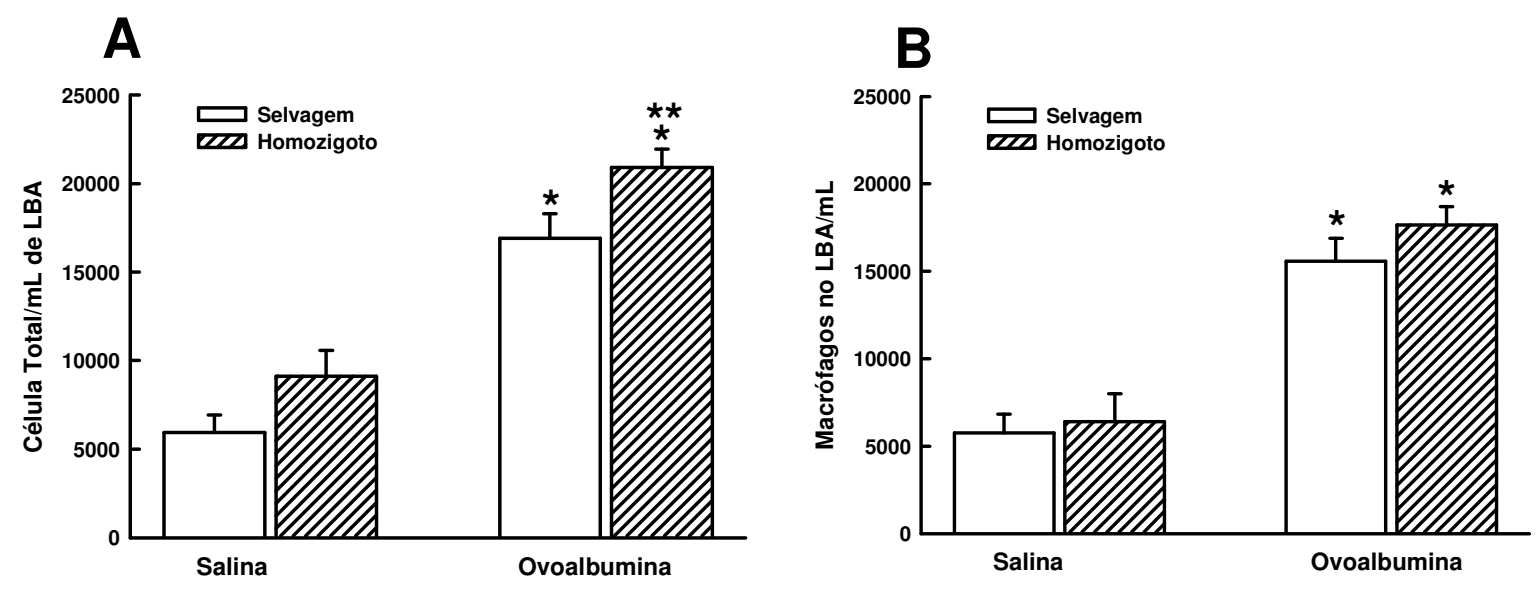

\section{C}
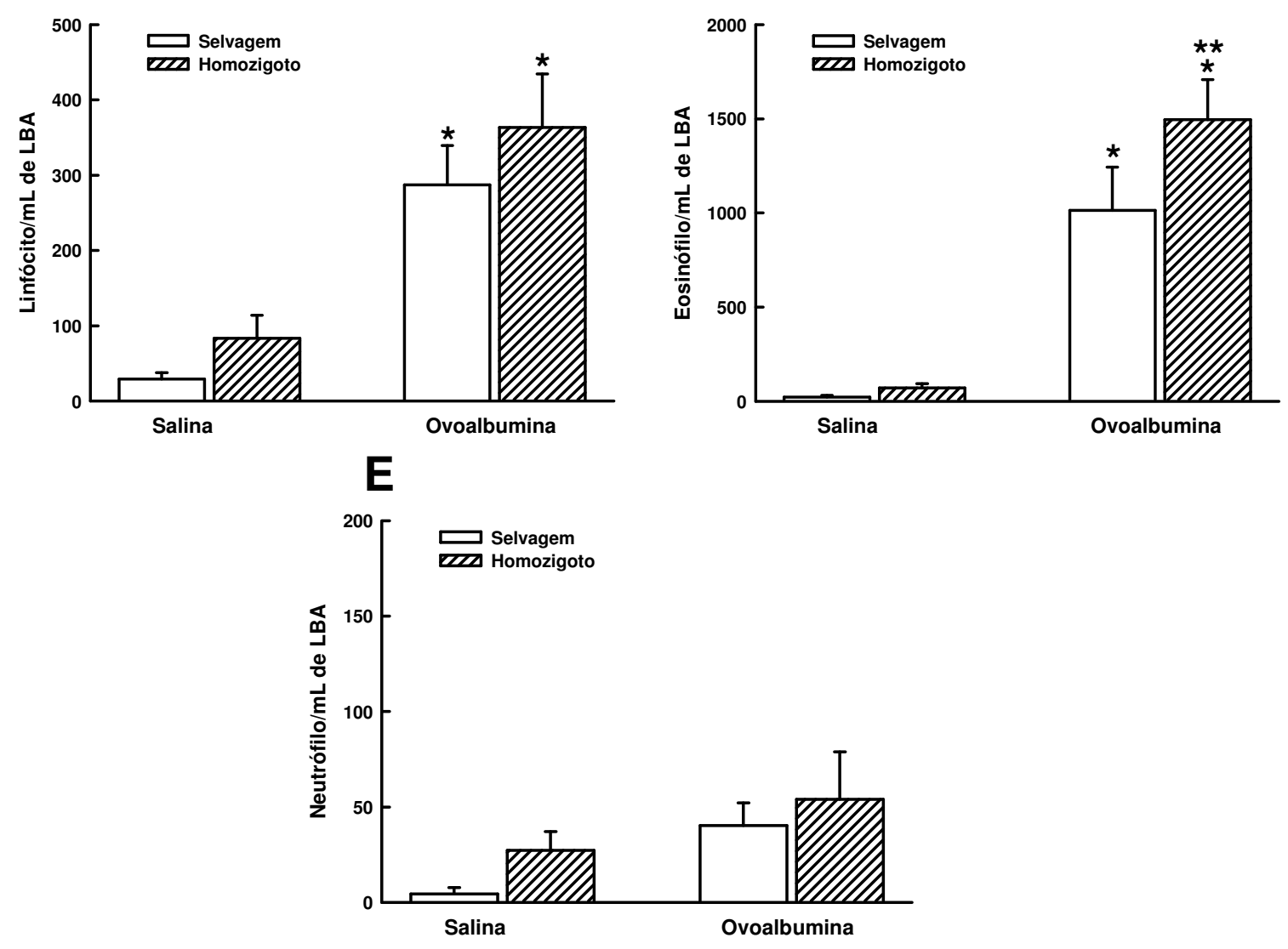

Figura 10. Média e erro padrão dos valores de células totais e macrófago, linfócitos, eosinófilos e neutrófilos no LBA. * $\mathrm{P} \leq 0,001$ comparado aos grupos salinas, respectivamente; ${ }^{* *} \mathrm{P}<0,05$ comparado ao grupo selvagemovoalbumina (WT-OVA). 


\subsection{Avaliação do Edema Peribrônquico}

$\mathrm{Na}$ Figura 11 observam-se os valores do índice de edema peribroncovascular expressos por área ( $\mu \mathrm{m} 2)$. Os animais do grupo HOMSAL $(7,36 \pm 0,53 / \mu \mathrm{m} 2)$ apresentaram aumento na área de edema peribrônquico nas vias aéreas comparativamente aos animais do grupo WT$\operatorname{SAL}(2,48 \pm 0,24 / \mu \mathrm{m} 2, \mathrm{P}<0,001)$. Considerando os animais sensibilizados, houve aumento significativo no edema peribroncovascular nos grupos WTOVA $(5,75 \pm 0,74 / \mu \mathrm{m} 2)$ e HOM-OVA $(11,11 \pm 0,58 / \mu \mathrm{m} 2)$ em comparação aos seus respectivos controles que receberam inalações de salina (WT-SAL e HOM-SAL, $P<0,01)$. A deficiência colinérgica nos animais sensibilizados (grupo HOM-OVA) ainda amplificou a área de edema peribrônquico comparativamente aos animais do grupo WT-OVA $(P<0,001)$.

\subsection{Células Inflamatórias Peribrônquicas}

$\mathrm{Na}$ Figura 12, podem-se observar os valores de células mononucleares (MN) (A) e polimorfonucleares (PMN) (B) quantificadas no espaço peribrônquico. Não houve diferença significativa entre os grupos WTSAL e HOM-SAL. Considerando os animais sensibilizados, houve aumento significativo no número de MN e PMN nos grupos WT-OVA [(MN: $\left.\left.3,74 \pm 0,46 / 10^{4} \mu \mathrm{m}^{2}\right), \quad\left(\mathrm{PMN}: \quad 8,71 \pm 1,52 / 10^{4} \mu \mathrm{m}^{2}\right)\right]$ e HOM-OVA [(MN: $\left.5,52 \pm 0,57 / 10^{4} \mu \mathrm{m}^{2}\right)$, (PMN: 15,55 $\left.\left.\pm 1,30 / 10^{4} \mu \mathrm{m}^{2}\right)\right]$ em comparação aos seus respectivos controles que receberam inalações de salina [WT-SAL (MN: $\left.2,14 \pm 0,25 / 10^{4} \mu \mathrm{m}^{2}\right), \quad\left(\mathrm{PMN}: \quad 3,33 \pm 0,66 / 10^{4} \mu \mathrm{m}^{2}\right)$ e HOM-SAL (MN: $\left.\left.2,91 \pm 0,39 / 10^{4} \mu m^{2}\right), \quad\left(P M N: 2,19 \pm 0,30 / 10^{4} \mu m^{2}\right) \quad(P<0,05)\right] . \quad A$ deficiência colinérgica nos animais sensibilizados (grupo HOM-OVA) aumentou o número de células $\mathrm{MN}$ e $\mathrm{PMN}$ ao redor das vias aéreas comparativamente aos animais do grupo WT-OVA $(\mathrm{P}<0,05)$. 


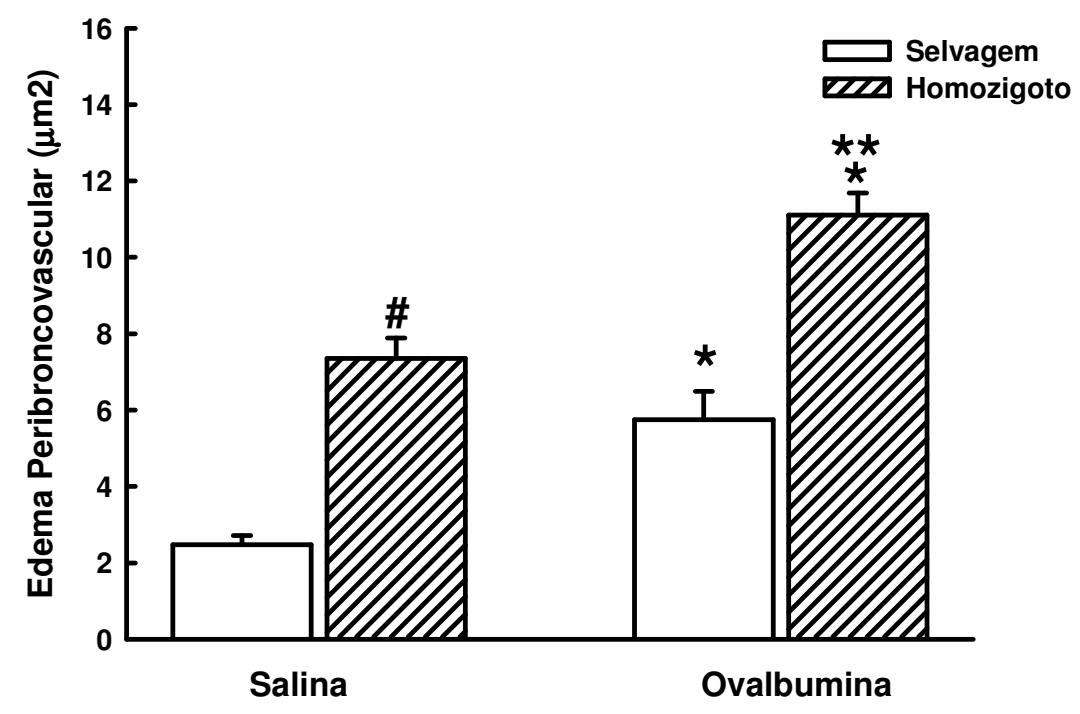

Figura 11. Média e erro padrão dos valores de edema peribrônquico nos quatro grupos estudados. \#P<0,001 comparado ao grupo WT-SAL; ${ }^{*} P<0,01$ comparados aos grupos WT-SAL e HOM-SAL, respectivamente; ${ }^{* *} \mathrm{P}<0,001$ comparado ao grupo WT-OVA. 
A

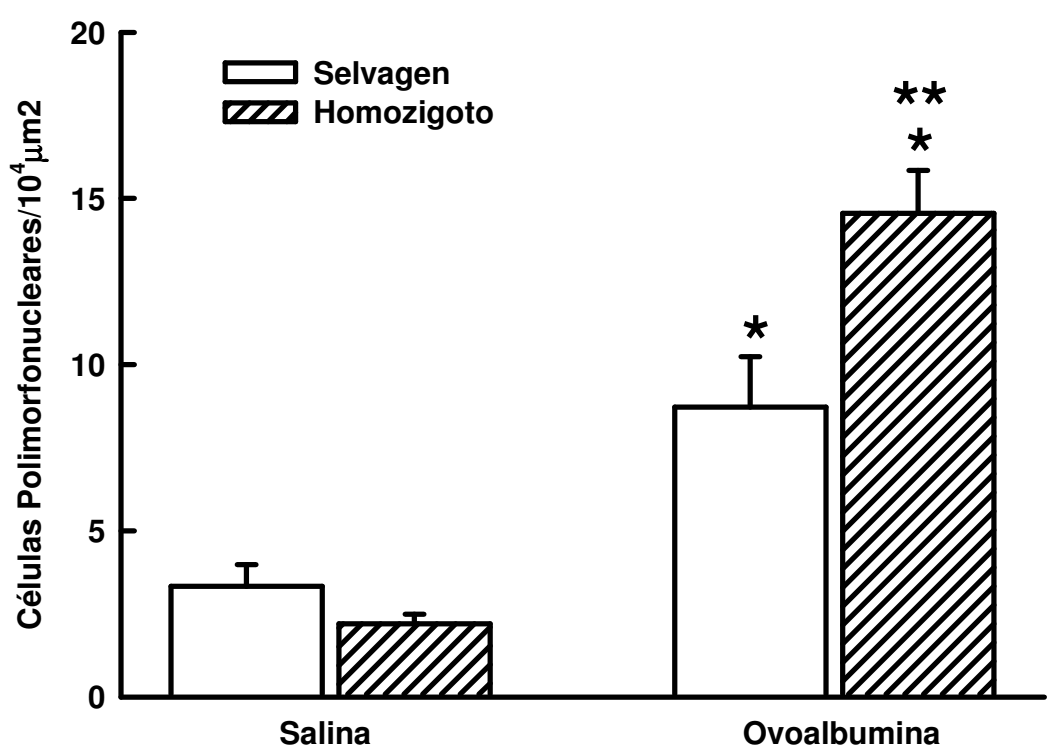

B

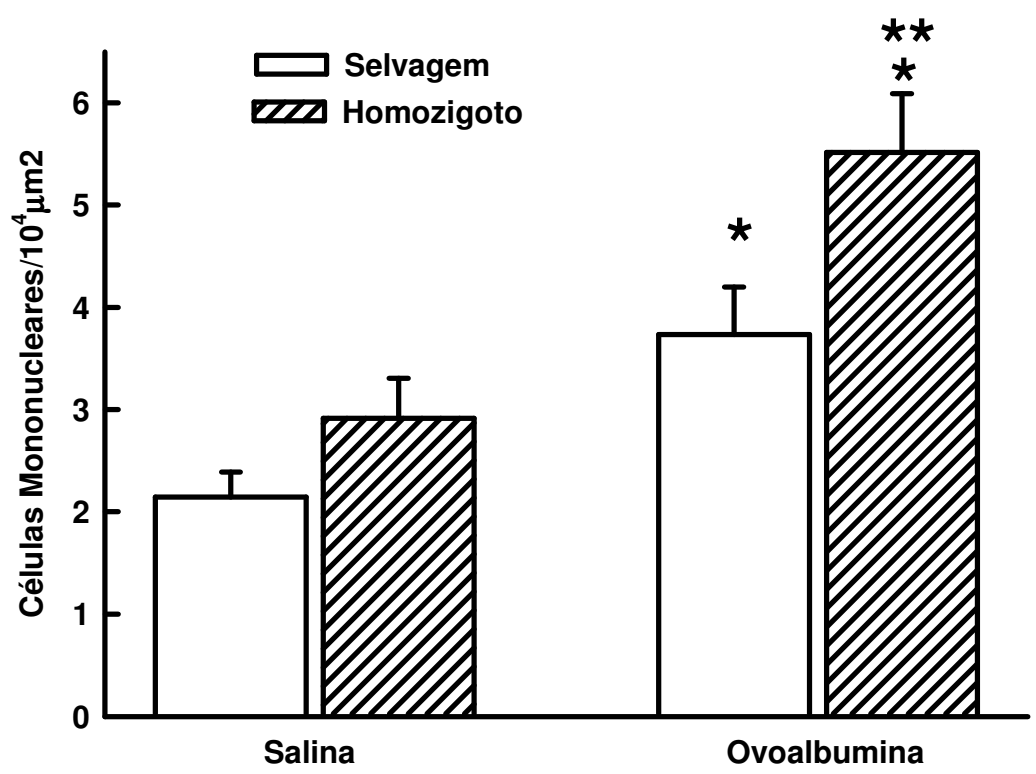

Figura 12. Média e erro padrão dos valores de células mononucleares e polimorfonucleares ao redor das vias aéreas nos quatro grupos estudados. ${ }^{*} \mathrm{P}<0,05$ comparados aos grupos WT-SAL e HOM-SAL, respectivamente; ${ }^{* *} \mathrm{P}<0,05$ comparado ao grupo WT-OVA. 


\subsection{Remodelamento de Vias Aéreas}

Para avaliar o remodelamento, foram quantificadas as fibras colágenas e elásticas na parede das vias aéreas por análise de imagens. $\mathrm{Na}$ Figura $13 \mathrm{~A}$ pode-se observar a porcentagem de fibras colágenas ao redor das vias aéreas nos quatro grupos estudados. Os animais do grupo HOMSAL $(27,48 \pm 1,67)$ apresentaram aumento da deposição de fibras colágenas nas vias aéreas comparativamente aos animais do grupo WT-SAL $(20,16 \pm 1,30, \quad P<0,05)$. A sensibilização com ovoalbumina induziu um aumento no conteúdo de fibras colágenas nos grupos WT-OVA $(33,71 \pm 3,03)$ e HOM-OVA $(42,31 \pm 2,03)$ quando comparado aos seus respectivos controles que receberam inalações com salina $(P<0,001)$. A deficiência colinérgica nos animais sensibilizados (Grupo HOM-OVA) amplificou a área de fibras colágenas nas vias aéreas comparativamente aos animais do grupo WT-OVA $(P<0,05)$.

Considerando o conteúdo de fibras elásticas nas vias aéreas, houve um aumento destas fibras nos animais do grupo HOM-SAL $(27,42 \pm 3,29)$ comparativamente aos animais do grupo WT-SAL $(19,18 \pm 1,98, \mathrm{P}<0,05)$. A sensibilização com ovoalbumina induziu um aumento no conteúdo de fibras elásticas apenas nos animais do grupo WT-OVA $(31,40 \pm 2,26)$ quando comparado ao seu respectivo controle que recebeu inalações com salina (WT-SAL, $P<0,001$ ). A deficiência colinérgica nos animais sensibilizados não interferiu na resposta de fibras elásticas nas vias aéreas, não havendo diferença significativa entre os grupos WT-OVA e HOM-OVA $(29,81 \pm 1,65)$ e tampouco entre os grupos HOM-OVA e HOM-SAL. 

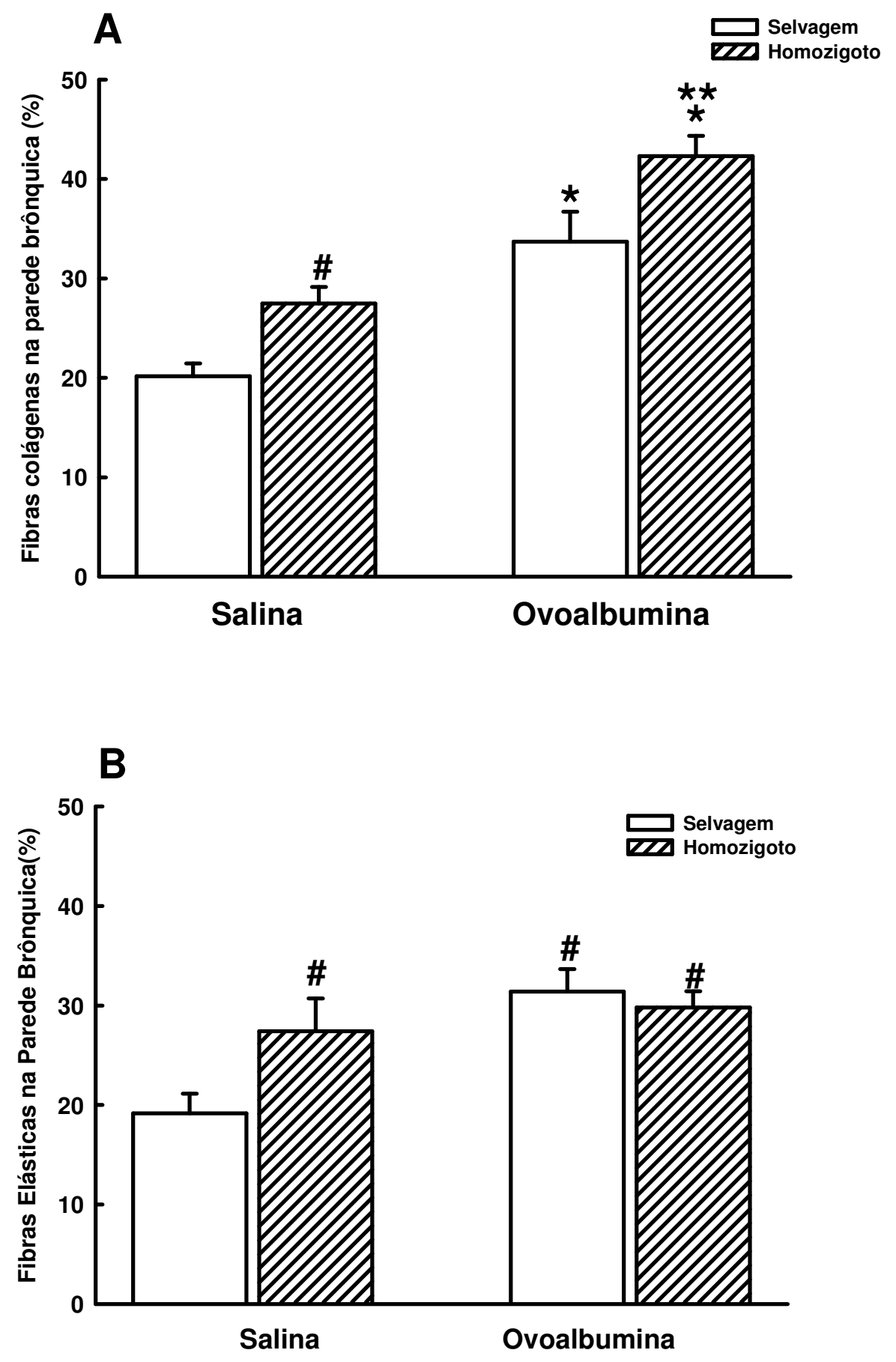

Figura 13. Média e erro padrão dos valores de fibras colágenas e elásticas na parede das vias aéreas nos quatro grupos estudados. $\# P<0,05$ comparado ao grupo WT-SAL; ${ }^{*} \mathrm{P}<0,001$ comparados aos grupos WT-SAL e HOM-SAL, respectivamente; ${ }^{* \star} \mathrm{P}<0,05$ comparado ao grupo WT-OVA. 


\subsection{Citocinas no Pulmão}

Foram analisados os níveis de TNF- $\alpha$, IL-4 e IL-10 no homogenato do pulmão dos animais estudados (Figura 14, A, B, E). Além disso, avaliamos IL-4 e IL-13 nas células inflamatórias por imunohistoquímica (Fig 14 C e D).

Considerando os níveis de TNF- $\alpha$, observamos que, embora não haja diferença dos níveis de TNF- $\alpha$ (14A) nos animais sensibilizados em comparação com os controles, houve aumento nos animais homozigotos [(HOM-SAL: $16,65 \pm 1,87)$ e (HOM-OVA: 18,39 $\pm 6,48)]$ em comparação aos selvagens [(WT-SAL: 10,82 $\pm 1,61)$ e (WT-OVA: 7,53 $\pm 1,36)](P<0,05)$.

Considerando os níveis de a IL-4 no homogenato pulmonar (4B), observamos que não houve diferença entre os animais salinas. Os animais sensibilizados e homozigotos (HOM-OVA: 6,58 $\pm 1,06$ )] apresentaram níveis de IL-4 maiores que os salinas [(WT-SAL: $2,36 \pm 0,60)$ e (HOM-SAL: $1,46 \pm 1,27)$ e que os animais sensibilizados e selvagem [(WT-OVA: $3,01 \pm 1,14),(P<0,05)$. Observamos também a expressão desta interleucina nas células inflamatória ao redor das vias aéreas (4C). Notamos que, não há diferença entre os animais salinas. Os animais sensibilizados [(WT-OVA: $1,97 \pm 0,457)$ e (HOM-OVA: $4,38 \pm 0,387)]$ apresentaram valores maiores de células positivas para IL-4 ao redor das vias aérea comparados aos grupos salina, [(WT-SAL: $0,35 \pm 0,42)$ e (HOM-SAL: 1,01 $\pm 0,46)$ ] respectivamente $(P<0,05)$. Ainda, houve amplificação desta resposta nos animais do grupo HOM-OVA comparado ao grupo WT-OVA $(\mathrm{P}<0,05)$.

Considerando as células positivas para IL-13 (D), notamos que, não há diferença entre os animais salinas. Os animais sensibilizados [(WT-OVA: $2,07 \pm 0,35)$ e (HOM-OVA: 4,11 $\pm 0,747)]$ apresentaram valores maiores de células positivas para IL-13 ao redor das vias aérea comparado aos grupos salina [(WT-SAL: $1,03 \pm 0,42)$ e (HOM-SAL: $1,14 \pm 0,16), P<0,05)]$. Ainda, houve amplificação desta resposta nos animais do grupo HOM-OVA comparado ao grupo WT-OVA $(P<0,05)$. 
No intuito de avaliar se a deficiência colinérgica interferia com interleucinas antiinflamatórios, avaliamos os níveis de IL-10 no homogenato pulmonar e as células positivas ao redor das vias aéreas. Observamos que não houve diferença estatisticamente significativa entre os grupos experimentais no homogenato pulmonar (Figura 14E) [(WT-SAL: 5,34 $\pm 1,15$ ),

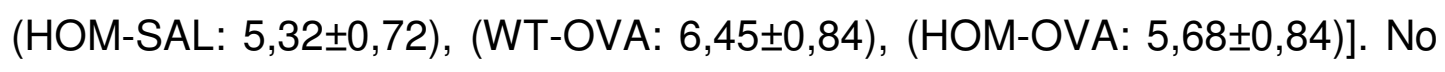
pulmão, houve maior número de células positivas para $\mathrm{IL}-10$ nos animais sensibilizados [(WT-OVA: $\left.\quad 1,79 \pm 0,35 / 10^{4} \mu \mathrm{m}^{2}\right), \quad$ (HOM-OVA: $\left.\left.1,93 \pm 0,32 / 10^{4} \mu \mathrm{m}^{2}\right)\right]$ em comparação aos salinas [(WT-SAL: 0,64 $\left.\pm 0,35 / 10^{4} \mu \mathrm{m}^{2}\right)$, (HOM-SAL: $\left.\left.1,24 \pm 0,30 / 10^{4} \mu \mathrm{m}^{2}\right), \mathrm{P}<0,05\right]$, no entanto a deficiência colinérgica não alterou esta resposta.

\subsection{Expressão de MMP-9 e TIMP-1 em Células Inflamatórias}

Avaliamos as células positivas para MMP-9 e para TIMP-1 (Figura 15). Observamos que os animais HOM-SAL apresentam maiores valores de células positivas em comparação ao WT-SAL $(P<0,05)$. A sensibilização com ovoalbumina induziu um aumento das células positivas para MMP-9 e para TIMP-1 nos grupos WT-OVA [(MMP-9: 9,06 $\pm 1,95)$, (TIMP-1: 6,94 $\pm 1,12)]$ e

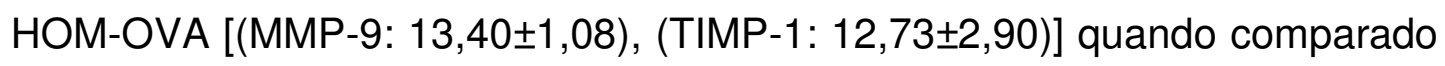
aos seus respectivos controles que receberam salina [WT-SAL: (MMP-9:

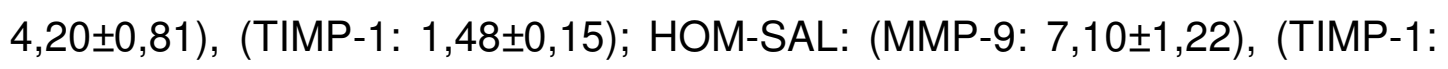
$5,12 \pm 0,55),(P<0,05)]$. A deficiência colinérgica nos animais sensibilizados (Grupo HOM-OVA) amplificou o número de células positivas para MMP-9 e para TIMP-1 quando comparado ao grupo WT-OVA $(\mathrm{P}<0,05)$.

Na Figura 16, observamos a coloração de HE (A-C), PicroSírius (D-F), imunohistoquímica para MMP-9 (G-I) e TIMP-1 (J-L) dos animais controle (WT-SAL - primeira coluna), e sensibilizados selvagem (WT-OVA, segunda coluna) ou homozigoto (HOM-OVA, terceira coluna). Nota-se que os animais sensibilizados apresentam mais inflamação peribrônquica e deposição de fibras colágenas, assim como maior coloração de MMP-9 e TIMP-1. 

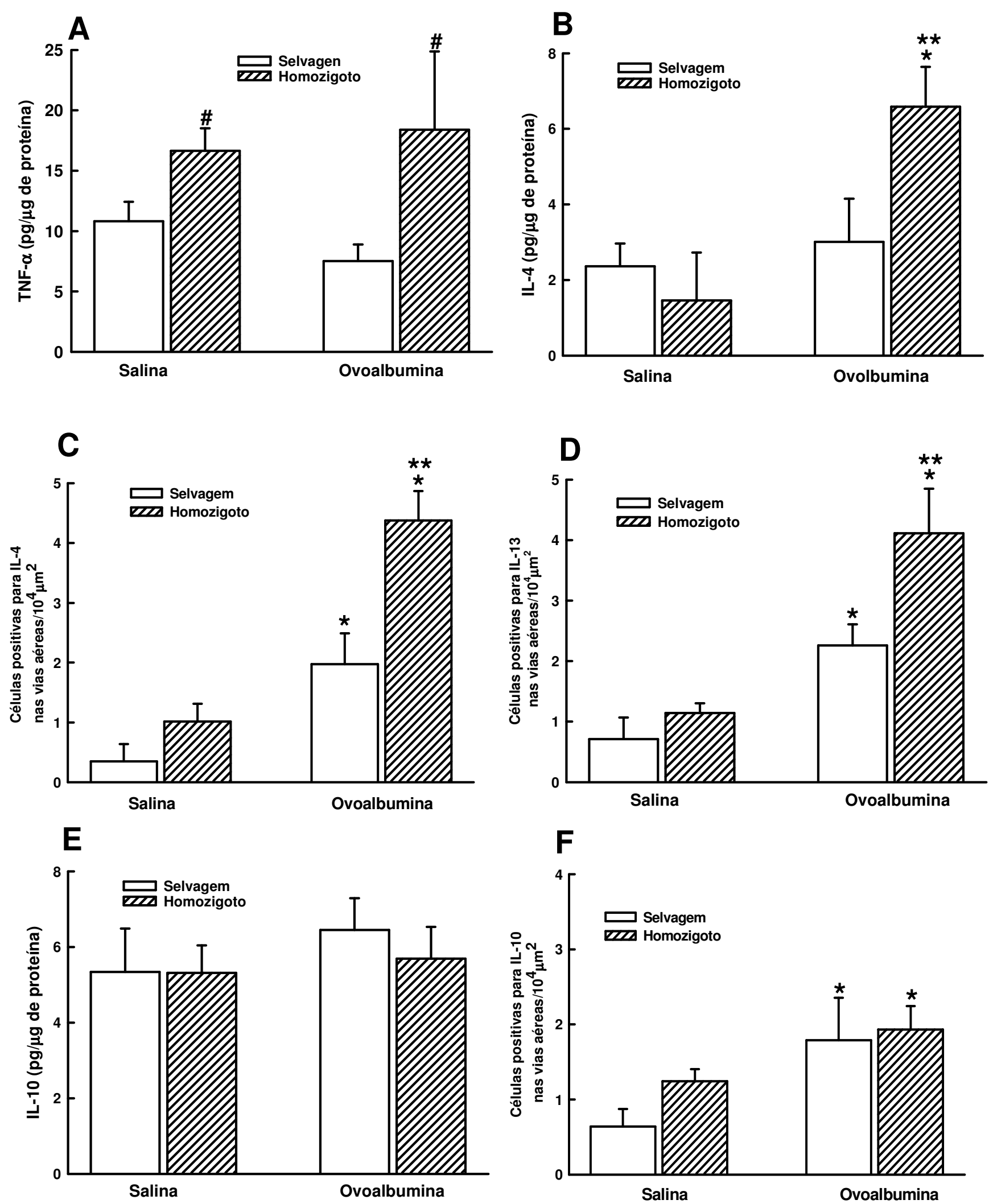

Figura 14. Média e erro padrão dos valores de fibras colágenas e elásticas na parede das vias aéreas nos quatro grupos estudados. $\# \mathrm{P}<0,05$ comparado ao grupo WT-SAL e WT-OVA, respectivamente; ${ }^{*} \mathrm{P}<0,05$ comparados aos grupos WT-SAL e HOM-SAL, respectivamente; ${ }^{* *} \mathrm{P}<0,05$ comparado ao grupo WT-OVA. 

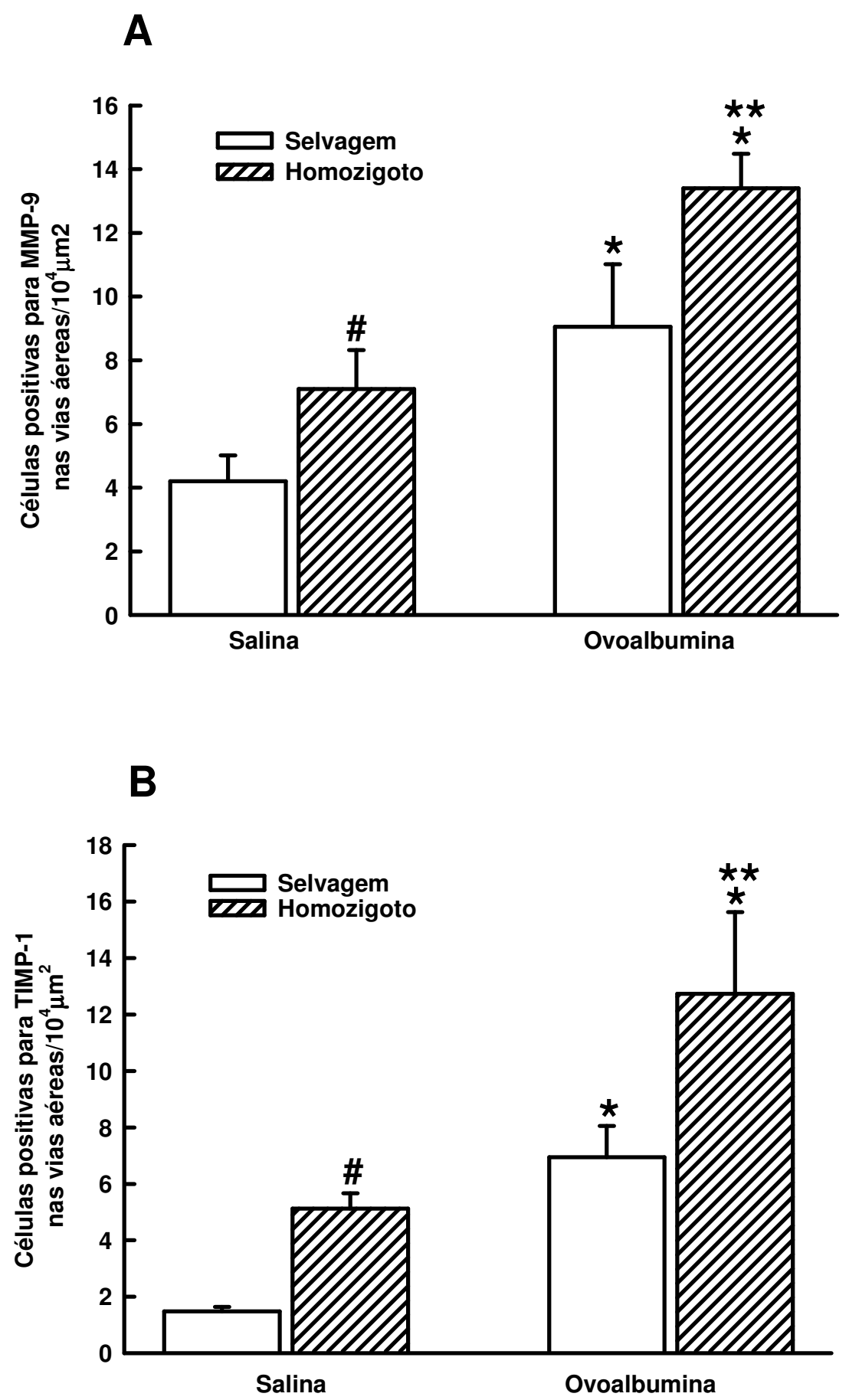

Figura 15. Média e erro padrão dos valores de células positivas para MMP-9 (A) e TIMP-1 (B) na parede das aéreas nos quatro grupos estudados. $\# \mathrm{P}<0,05$ comparado ao grupo WT-SAL; ${ }^{*} \mathrm{P}<0,05$ comparados aos grupos WT-SAL e HOM-SAL, respectivamente; ${ }^{* *} \mathrm{P}<0,05$ comparado ao grupo WTOVA. 

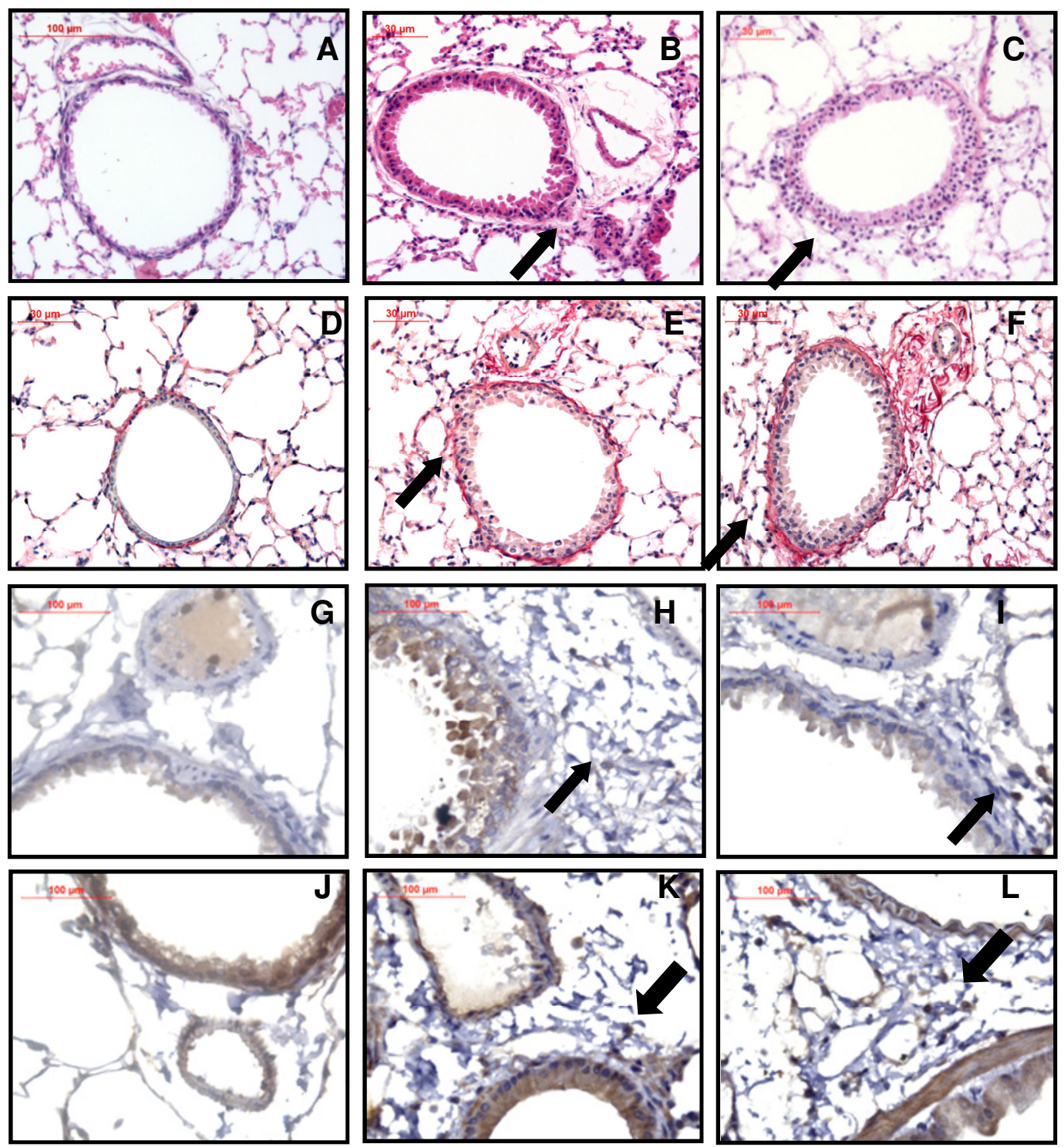

Figura 16. Fotomicrografia de via aérea de pulmão retirados do animal do grupo WT-SAL (primeira coluna), WT-OVA (segunda coluna) e HOM-OVA (terceira coluna). Painéis A-C: Coloração HE; Painéis D-F: Coloração PicroSírius; Painéis G-I: Imunohistoquímica para MMP-9; Painéis $\mathrm{J}-\mathrm{L}$ : Imunohistoquímica para TIMP-1. 
O presente estudo demonstrou, em animais mutantes com redução na expressão de VAChT submetidos a protocolo de indução alérgica crônica com ovoalbumina, que houve piora do edema peribrônquico e da inflamação eosinofílica assim como aumento da expressão de IL-4 e IL-13 no pulmão. Houve ainda aumento da deposição de fibras colágenas pulmonares, sugerindo maior remodelamento pulmonar nos animais mutantes sensibilizados, e isso se deve provavelmente ao aumento do número de células positivas para MMP-9 e TIMP-1. Provavelmente todas estas alterações contribuíram para a exacerbação da hiperresponsividade brônquica observada nestes animais. Estes dados sugerem que a deficiência da função colinérgica está envolvida na inflamação pulmonar alérgica crônica por interferência com o reflexo colinérgico antiinflamatório (Pavlov e Tracey, 2006), sendo esta uma nova via envolvida na fisiopatogenia da asma brônquica, que merece ser melhor investigada.

A liberação de ACh na junção neuromotor e sua ação no sistema nervoso periférico eferente, em receptores muscarínicos ou nicotínicos (Pavlov e Tracey, 2005), depende diretamente da presença de VAChT nas vesículas sinápticas. A VAChT é expressa tanto no sistema nervoso central quanto periférico. Considerando a periferia, a VAChT é expressa em diferentes órgãos, incluindo coração, o tracto gastrointestinal, e os outros (Pavlov, Tracey, 2005). No pulmão, fibras imunoreativas para VAChT foram identificadas na camada de músculo liso perto de epitélio na traquéia e brônquios (Arvidsson et al., 1997). Além disso, a expressão de VAChT já foi também identificada no epitélio das vias aéreas (Lips et al., 2005), nos brônquios de macacos (Proskocil et al., 2004), em células secretoras da traquéia e nos brônquios de roedores (Lips et al., 2007; Adriaensen et al., 2003).

Castro et al. (2009) desenvolveram animais Knockout para VAChT, e observaram que os animais homozigotos morreram minutos após o nascimento, com intensa cianose, sugerindo que a VAChT e a neurotransmissão colinérgica é essencial para a manutenção da vida. Desta 
forma, o distúrbio genético da neurotransmissão colinérgica em modelos animais é complexo. Considerando a abundância dos receptores da ACh, estudos de receptores individuais podem não revelar todas as consequências da diminuição do tônus colinérgico in vivo. Neste sentido, a utilização de camundongos geneticamente modificados com expressão alterada ou suprimida de genes relevantes é de particular interesse para demonstrar a importância de um único mediador único. Neste sentido, Prado et al. (2006a) geraram um modelo de camundongos com disfunção colinérgica (VAChT knockdown, homozigotos [VAChT KDHOM]), onde animais homozigotos apresentam redução de aproximadamente $70 \%$ nos níveis de VAChT (Castro et al., 2009).

No presente estudo, utilizamos este modelo para um melhor conhecimento dos efeitos da redução da função colinérgica na inflamação alérgica crônica de vias aéreas. Embora a modificação genética não seja totalmente fisiológica e por isso os resultados obtidos em modelos geneticamente modificados devam ser cautelosamente interpretados, este estudo é inovador, isolando especificamente as ações da ACh na resposta imune inata, particularmente no que se refere à avaliação das alterações pulmonares em modelo experimental de asma, permitindo a avaliação das ações da redução função colinérgica in vivo por longo prazo.

Os animais mutantes (HOM-SAL) sem indução da inflamação alérgica pulmonar já apresentam algumas alterações pulmonares, sendo o extravasamento de líquido e a deposição de fibras colágenas e elásticas ao redor das vias aéreas as alterações significativas. Estas alterações estão provavelmente relacionadas à redução da função antiinflamatória do sistema colinérgico. No presente estudo detectamos um aumento de TNF- $\alpha$ nos animais homozigotos submetidos ao protocolo de salina, além de aumento na expressão de MMP-9/TIMP-1. Considerando que a alteração genética foi de longo prazo, o processo de remodelamento e o aumento de metaloproteinases/inibidores ocorra no sentido de manter a homeostasia 
pulmonar, uma vez que não observamos diferenças na inflamação e na função pulmonar.

Considerando o extravasamento do edema peribrônquico observado nos animais não sensibilizados mutantes, a hipótese mais provável é que esta resposta esteja correlacionada ao aumento dos níveis de TNF- $\alpha$, mediador pró-inflamatório. Cabe ressaltar ainda que animais VAChT Knockdown evoluem com insuficiência cardíaca, podendo o edema ser de origem cardiogênica. No entanto, Lara et al. (2010) só encontrou insuficiência cardíaca esquerda em animais com deficiência colinérgica a partir de 6 meses de vida, idade mais tardia que os animais utilizados no presente estudo (aproximadamente 2 meses).

O braço eferente do nervo vago é uma importante via antinflamatória devido a liberação de $\mathrm{ACh}$ que interage com receptores colinérgicos nicotínicos (Gallowitsch-Puerta et al., 2005). A função do sistema colinérgico anti-inflamatório já foi descrita em modelos de inflamação sistêmica aguda (Van Westerloo et al, 2005;. Wang et al, 2004;. Song et al, 2008; Goldstein et al, 2007) e os autores, em sua maioria, atribuem os efeitos antiinflamatórios à atuação da $\mathrm{ACh}$ nos receptores $\alpha 7 \mathrm{nAChR}$, que modula o NFkB, inibindo a liberação de citocinas. No entanto, poucos estudos avaliaram o sistema colinérgico antiinflamatório no pulmão. Su et al. (2007) e (2010) mostraram que a estimulação de receptores colinérgicos suprime a inflamação pulmonar aguda em ratos, provavelmente pelos efeitos de ACh no a7nAChR.

Utilizamos modelo de inflamação alérgica induzida por via subcutânea sem associação de adjuvante previamente descrito por Conrad et al. (2009). Os animais WT-OVA apresentaram aumento de macrófagos, linfócitos e eosniófilos no LBA e infiltrado de células MN e PMN ao redor das vias aéreas, além de intenso edema peribrônquico. O aumento da expressão de IL-4 e IL-13 observada nos animais selvagens e sensibilizados corrobora com outros dados experimentais e clínicos que claramente mostraram que 
estas citocinas estão envolvidas na adesão e no recrutamento de eosinófilos e na sua sobrevivência (Brusselle et al., 1994, Vieira et al., 2007). Os eosinófilos também contribuem para o remodelamento de vias aéreas e para o desenvolvimento de hiper-responsividade brônquica (Hara et al., 2006), características observadas no presente estudo nos animais sensibilizados com ovalbumina. O número de células positivas para MMP-9 e TIMP-1 em células inflamatórias também estava aumentado nos WT-OVA e provavelmente estas alterações foram responsáveis pelo processo de remodelamento observado nestes animais. Em conjunto, os dados acima apresentados demonstram a eficácia deste modelo de asma experimental que mimetiza aspectos importantes da asma humana.

Corroborando outros modelos da literatura, o modelo utilizado não apresentou inflamação neutrofílica no LBA. Provavelmente isso ocorreu devido ao fato de trabalharmos com inflamação crônica. Sabe-se que os neutrófilos, embora envolvidos na asma principalmente do tipo grave, são células que estão aumentadas principalmente na resposta aguda ao estímulo (Kawakami et al., 2008).

Curiosamente, a deficiência colinérgica piorou a hiperresponsividade brônquica em resposta à metacolina nos animais sensibilizados quando comparado a animais sensibilizados e selvagens. A ACh é um potente broncconstritor, principalmente por ação nos receptores muscarínicos presentes no músculos lisos e glândulas submucosas (Rogers, 2001). No entanto, o papel dos receptores nicotínicos da função pulmonar não foi esclarecido. Corroborando com nossos dados, Dorion et al. (2005), estudando modelo experimental de murinos, utilizaram o agonista nicotínico não seletivo 1,1-dimetilfenil 1,4-piperazinium que induziu maior relaxamento na musculatura lisa da traqueia. Estes resultados sugerem que receptores nicotínicos também possam participam dos mecanismos de regulação do tônus muscular, induzindo a broncodilatação. 
É também importante salientar que, embora o principal determinante de alterações mecânicas do pulmão seja a contração do músculo liso das vias aéreas, a presença de edema, inflamação e deposição de fibras colágenas contribuindo com 0 aumento da resistência do sistema respiratório por redução do diâmetro do lumen das vias aéreas. Neste contexto, os animais mutantes sensibilizados (HOM-OVA) apresentaram maior edema das vias aéreas, inflamação e remodelamento que poderiam explicar os resultados da piora da função pulmonar. Por fim, a deficiência colinérgica pode ainda interferir com a liberação de outros mediadores inflamatórios, como o óxido nítrico, ativação de fibras $\mathrm{C}$, que podem também corroborar com a piora da hiperresponsividade brônquica.

Não observamos diferenças significativas na elastância do sistema respiratório em nenhum dos grupos estudados. Embora tenha havido alterações nos componentes de fibras elásticas nos animais WT-OVA, estas alterações histológicas não correspondem a alterações na Ers. Isso pode ocorrer porque medimos a elastância do sistema respiratório e não somente de tecido pulmonar. Talvez medidas de mecânica mais sofisticadas pudessem detectar estas diferenças. Considerando a deficiência colinérgica, a imunorreatividade para os componentes do sistema colinérgico nas vias aéreas é mais acentuada nas vias aéreas proximais, sendo que as vias aéreas distais até a nona geração não são inervadas pelo parassimpático (Barnes et al., 1998; Left, 1982).

A resposta inflamatória é caracterizado por alteração da permeabilidade endotelial e recrutamento de células inflamatórias. Neste contexto, os animais mutantes sensibilizados apresentaram um aumento do edema peribronquico assim como do infiltrado de células $M N$ e PMN ao redor das vias aéreas quando comparado aos animais selvagens sensibilizados. Além disso, avaliamos ainda a inflamação no LBA e observamos os efeitos da deficiência colinérgica amplificando a resposta inflamatória eosinofílica. Não houve diferença nos outros tipos de células inflamatórias no LBA entre os grupos WT-OVA e HOMO-OVA. Pelo que 
sabemos, estes dados mostram pela primeira vez a importância da Ach endógena no controle da inflamação alérgica de vias aéreas.

Os efeitos da deficiência colinérgica amplificando a inflamação foram previamente relatadas por outros autores em diferentes modelos experimentais. Van Westerloo et al. (2005) mostraram que os ratos vagotomizados apresentaram um aumento de células inflamatórias no fluido peritoneal após peritonite séptico, aumentando respostas inflamatórias aguda e crônica, sugerindo que o sistema anti-inflamatório colinérgica é importante na defesa do hospedeiro. Hofer et al. (2008) mostraram que a inibição da acetilcolinesterase pelo tratamento com fisostigmina reduziu a mortalidade e os níveis de citocinas pró-inflamatórias.

No que diz respeito aos níveis de citocinas, medimos a IL-4 e a IL-13, citocinas pró-inflamatórias de resposta Th2 e a IL-10, uma citocina antiinflamatória, no pulmão. Animais mutantes sensibilizados apresentaram maior número de células positivas para a expressão de IL-4 e também maior quantidade de IL-4 no homogenato pulmonar. Os nossos resultados estão de acordo com Zhu e Gilmour (2009) que mostraram que camundongos da linhagem C57BL/6J tem aumento da inflamação eosinofílica dependente de IL-4, sem necessariamente interferir com outras citocinas, como IL-5, sugerindo assim que a IL-4 seja uma citocina de crucial importância para a manutenção da inflamação eosinofílica. Mostramos também que o número de células inflamatórias positivas para IL-13 também foi maior nos animais do grupo HOM-OVA em comparação ao grupo WT-OVA. Outros autores já demonstraram a importância destas citocinas na resposta alérgica (Corren, 2011, Williams et al., 2012), embora no presente estudo não tenhamos detectado níveis suficientes de IL-13 no homogenato pulmonar (dados não mostrados).

No intuito de avaliar se a deficiência colinérgica modula as citocinas anti-inflamatórias, avaliamos no homogenato pulmonar a quantidade de IL10. Não foram notadas diferenças significativas entre os grupos 
experimentais. Considerando as células inflamatórias para IL-10 ao redor das vias áereas, houve apenas efeito da sensibilização, sem haver qualquer diferença entre os grupo HOM e WT. Corroborando nossos achados, Borovikova et al., (2000) demonstraram que a estimulação eléctrica directa do nervo vago periférico in vivo inibiu os níveis de IL-1 $\beta$, IL-6, IL-8 e TNF- $\alpha$, sem qualquer efeito nos níveis de IL-10. Em conjunto, estes dados sugerem que a deficiência colinérgica contribuiu com a piora da inflamação pulmonar alérgica, aumentando diretamente os níveis de citocinas pró-inflamatórias, sem intereferência com citocinas antiinflamatórias.

Como citado anteriormente, os níveis de TNF- $\alpha$ foi maior nos animais HOM-OVA do que nos animais WT-OVA, não sendo alterado pela indução da sensibilização alérgica. Embora o TNF- $\alpha$ seja uma citocina central envolvida na resposta inflamatória (Johnston, Webster, 2009), o seu papel na patogenia da asma permanece ainda é controverso. Cho et al (2011) mostraram redução de eosinófilos peribrônquicos e do remodelamento peribrônquica em animais com deficiência de receptores de TNF- $\alpha$. Vários estudos têm sugerido que o TNF- $\alpha$ desempenha um papel importante na patogênese da asma (Bradding et al.,1994; Broide et al.,1992; Keatings et al.,1997) e que o TNF-a induz o agravamento da hiperresponsividade em animais (Kips et a., 1992 e Zuany-Amorim et al., 1995) e humanos (Thomas et al., 1995). Por outro lado, outros observaram aumento de TNF- $\alpha$ somente em pacientes com asma grave (Corren, 2011), sugerindo que o TNF-- $\alpha$ tenha importância somente na asma severa e nas formas refratárias da doença (Desai, Brightling, 2010). No presente estudo, a sensibilização per se não intereferiu com os níveis de TNF-- $\alpha$. Considerando ainda que os níveis de TNF-- $\alpha$ foram semelhantes nos animais HOM-SAL e HOM-OVA, não podemos atribuir as alterações observadas nos animais HOM-OVA aem relação ao WT-OVA à este mediador.

A persistência da inflamação crônica pode induzir a uma reparo do tecido, conhecido como remodelamento, que envolve alterações estruturais da parede das vias aéreas com uma deposição muitas vezes desarranjada 
das fibras da MEC. Embora exista uma grande discussão se 0 remodelamento oocorre no sentido de proteger a via aérea ou se esta alteração estrutural é responsável pela hiperresponsividade, parece que o remodelamento pulmonar tem um importante significado clínico nos pacientes asmáticos contribuindo para a pior função pulmonar observada ao longo dos anos (Phipps et al., 2004). Os animais homozigotos que foram submetidos a sensibilização apresentaram um aumento no conteúdo de fibras colágenas, sem alterar a deposição de fibras elásticas, quando comparado aqueles sensibilizados e selvagens.

A piora da inflamação eosinofílica induzida pela deficiência de VAChT poderia explicar per se o maior remodelamento da MEC uma vez que estas células estão envolvidas na liberação de diferentes tipos de mediadores prófribróticos e citocinas (Chetta et al., 1997) que podem induzir um efeito proliferativo no músculo liso de vias aéreas (Gosens et al., 2008), além de intereferirem com o equilíbrio de MMP/TIMP (Chetta et al., 1996).

O equilíbrio das MMP e dos TIMP tem um papel fundamental na imunomodulação da composição da MEC na patogénese da asma (Elshaw et al, 2004, Araújo et al, 2008). Demonstramos que a deficiência colinérgica em animais submetidos ao protocolo de sensibilização induziu um maior aumento tanto de células positivas para MMP-9 quanto para TIMP-1 ao redor das vias aéreas. Embora o aumento da MMP-9 e das fibras colágenas observadas no grupo HOM-OVA pareça ser controverso considerando que este grupo apresentou mais fibras colágenas, é importante notar que a relação do aumento de MMP-9/TIMP-1 foi menor no grupo HOM-OVA do que nos demais grupos. Neste sentido, a expressão de TIMP-1 aumento $757 \%$ em relação ao grupo controle, enquanto o aumento de células positivas para MMP-9, que degrada componentes da matriz extracelular, foi somente de $219 \%$ neste grupo, favorecendo assim a deposição de fibras da MEC. Além dos efeito na degradação de componentes da MEC, as MMPs também estão envolvidas no recrutamento de células inflamatórias e na defesas do hospedeiro (Greenlee et al., 2007). 
Corroborando nosso achados, Blanchet et al., (2007) utilizaram agonista nicotínico e observaram inibição da atividade de eosinófilos, da liberação de leucotrieno C4 e de MMP-9 in vitro. Inativando o a7nAChR in vitro, Maouche et al. (2009) observaram aumento da proliferação celular durante as etapas iniciais da regeneração epitelial, levando a alterações epiteliais, como a hiperplasia das células basais e metaplasia escamosa. Os autores sugerem que este receptor pode estar envolvido no remodelamento observado em diferentes doenças broncopulmonares.

Não observamos efeito do sistema colinérgico nas fibras elásticas. Não há consenso na literatura sobre as mudanças no sistema de fibras elásticas nas vias aéreas de pacientes asmáticos. Bousquet et al. (1996), em um estudo descritivo de biópsias brônquicas de asmáticos com diferentes gravidade da doença, observaram fragmentação da rede de fibras do sistema elástico na camada subepitelial, provavelmente devido à elastólise, resultando em aumento do fechamento das vias aéreas e aumento aparente da responsividade. Entretanto, Godfrey et al. (1995) sugeriram que a redução do conteúdo de fibras do sistema elástico não é uma característica da asma moderada ou fatal, e que não é um fator contribuinte à redução do recolhimento elástico relatado e ao desenvolvimento da hiperresponsividade da via aérea. Considerando o sistema colinérgico, nada se tem na literatura dos efeitos da ACh no conteúdo destas fibras.

O presente estudo tem algumas limitações uma vez que estamos cientes de que os animais não desenvolvem asma e por isso é necessário cautela na transposição de nossos achados para seres humanos. No entanto, os modelos animais são extremamente úteis para compreender melhor patogénese da doença e para avaliar as intervenções terapêuticas e novos mecanismos fisiopatológicos.

Em conclusão, os resultados obtidos no presente estudo mostraram que a deficiência colinérgica a longo prazo piorou a hiperresponsividade brônquica, inflamação e o remodelamento de fibras colágenas em modelo 
murino de asma experimental, por interferência com citocinas próinflamatórias e por afetar o equilíbrio MMP/TIMP no pulmão. Coletivamente, esses dados reforçam a idéia de que o sistema colinérgico modula a função pulmonar de diferentes maneiras e por isso os efeitos da ACh na fisiopatologia da doença pulmonar merece uma investigação mais aprofundada. 

A indução da deficiência colinérgica por redução da proteína transportadora de acetilcolina piorou a hiperresponsividade brônquica, a inflamação e o remodelamento de fibras colágenas em modelo experimental de inflamação pulmonar induzida pela exposição repetida a ovoalbumina.

Estas alterações ocorreram provavelmente pelo efeito da deficiência colinérgica aumentado os níveis de citocinas pró-inflamatórias, como IL-4 e IL-13, e também por afetar o equilíbrio MMP/TIMP no pulmão. Não houve efeito da deficiência colinérgica na citocina antiinflamatória IL-10. 
REFERÊNCIAS

BIBLIOGRÁFICAS 
Adriaensen D, Brouns I, Van Genechten J, Timmermans JP Functional morphology of pulmonary neuroepithelial bodies: extremely complex airway receptors. Anat Rec A Discov Mol Cell 2003;270:25-40.

Alving K, Fornhem C, Weitzberg E, Lundberg JM. Nitric oxide mediates cigarette smoke-induced vasodilatory responses in the lung. Acta Physiol Scand. 1992;146(3):407-8.

Angeli P, Prado CM, Xisto DG, Silva PL, Pássaro CP, Nakazato HD, LeickMaldonado EA, Martins MA, Rocco PR, Tibério IF. Effects of chronic LNAME treatment lung tissue mechanics, eosinophilic and extracellular matrix responses induced by chronic pulmonary inflammation. Am J Physiol Lung Cell Mol Physiol 2008;294(6):1197-205.

Araujo BB, Dolhnikoff M, Silva LF, Elliot J, Lindeman JH, Ferreira DS, Mulder A, Gomes HA, Fernezlian SM, James A, Mauad T. Extracellular matrix components and regulators in the airway smooth muscle in asthma. Eur Respir J. 2008 Jul;32(1):61-9.

Arvidsson ULF, Riedl M, Elde R, Meister B. Vesicular Acetylcholine Transporter (VAChT) Protein: A Novel and Unique Marker for Cholinergic Neurons in the Central and Peripheral Nervous Systems. The Journal of Comparative Neurology 1997;378:454-467.

Auchinlos HJ, Geha RS, Kay AB, Lechler R, Loke YW, Sprent J, Wraith D. Allergy and hypersensitivity. Immunobiology 1997;11:1-11:25.

Bafadhel M, McCormick M, Saha S, McKenna S, Shelley M, Hargadon B, Mistry V, Reid C, Parker D, Dodson P, Jenkins M, Lloyd A, Rugman P, Newbold $P$, Brightling CE. Profiling of sputum inflammatory mediators in asthma and chronic obstructive pulmonary disease. Respiration. 2012;83(1):36-44.

Barnes PJ and Belvisi MG. Nitric oxide and lung disease. Thorax 1993;48:1034-1043. 
Barnes PJ, Wang H, Liao H, Ochani M, Justiniani M, Lin X, Yang L, Al-Abed Y, Metz C, Miller EJ, Tracey KJ, Ulloa L. Cholinergic agonists inhibit HMGB1 release and improve survival in experimental sepsis. Nat Med 2004;(10):1216-1221.

Barnes PJ, Chung KF, Page CP. Inflammatory mediators of asthma: an update.Pharmacol Rev 1998; 50(4):515-96.

Barnes PJ. Cytokines modulators as novel therapies for asthma. Annu Rev Pharmacol Toxicol 2002;42:81-98.

Barnes PJ. Drugs for asthma.. Brit J Pharmacol 2006; 147: 297-303.

Bateman ED, Hurd SS, Barnes PJ, Bousque J, Drazen JM, FitzGerald M et al. Global strategy for asthma management and prevention: GINA executive summary. Eur Respir J 2008;31:143-178.

Bates SHT, Irvin CG. Measuring lung function in mice: the phenotyping ucertainly principle. J Appl Physiol 2003;94:1926-1936.

Blanchet MR, Israel-Assayag E, Cormier Y. Modulation of airway inflammation and resistance in mice by a nicotinic receptor agonist. Eur Respir J. 2005;26(1):21-7.

Blanchet MR, Langlois A, Israel-Assayag E, Beaulieu MJ, Ferland C, Laviolette $\mathrm{M}$, et al. Modulation of eosinophil activation in vitro by a nicotinic receptor agonist. J Leukoc Biol. 2007;81(5):1245-51.

Bleecker ER, Welch MJ, Weinstein SF, Kalberg C Johnson M, Edwards L, Rickard KA.. Low-dose inhaled fluticasone propionate versus oral zafirlukast in the treatment of persistent asthma. J Allergy Clin Immunol 2000;105(6 $1): 1123-9$.

Bleecker ER, Welch MJ, Weinstein SF, Kalberg C, Johnson M, Edwards L, Rickard KA.. Low-dose inhaled fluticasone propionate versus oral zafirlukast 
in the treatment of persistent asthma. J Allergy Clin Immunol. 2000;(6 1):1123-9.

Boland C, Collet V, Laterre E, Lecuivre C, Wittebole X, Laterre PF. Electrical vagus nerve stimulation and nicotine effects in peritonitis-induced acute lung injury in rats. Inflammation 2011;34(1):29-35

Borovikova LV, Ivanova S, Zgang M, Yang H, Botchkina GI, L Watkins LR, Wang $\mathrm{H}$, Abumrad $\mathrm{N}$, Eaton JW, Tracey KJ . Vagus nerve stimulation attenuates the systemic inflammatory response to endotoxin. Nature 2000;405:458-462

Bousquet J, Clark TJ, Hurd S, Khaltaev N, Lenfant C, O'byrne P, Sheffer A.GINA guidelines on asthma and beyond. Allergy 2007;62:102-12.

Bousquet J, Lacoste JY, Chanez P, Vic P, Godard P, Michel FB. Bronchial elastic fibers in normal subjects and asthmatic patients. Am $J$ Respir Crit Care Med 1996;153:1648-54.

Bradding P, Roberts JA, Britten KM, Montefort S, Djukanovic R, Mueller R, et al.Interleukin-4, -5, and -6 and tumor necrosis factor- $\alpha$ in normal and asthmatic airways: evidence for the human mast cell as a source of these cytokines..Am J Respir Cell Mol Biol 1994;10:471-480.

Brannan JD. Bronchial hyperresponsiveness in the assessment of asthma control: Airway hyperresponsiveness in asthma: its measurement and clinical significance. Chest. 2010;138(2):11-17.

Broide DH, Lotz M, Cuomo AJ, Coburn DA, Federman EC, Wasserman SI. Cytokines in symptomatic asthma airways. J Allergy Clin Immunol. 1992;89:958-967.

Brusselle GG, Kips JC, Tavernier JH, van der Heyden JG, Cuvelier CA, Pauwels RA, Bluethmann $\mathrm{H}$. Attenuation of allergic airway inflammation in IL4 deficient mice.. Clin Exp Allergy 1994;24(1):73-80.. 
Buc M, Dzurilla M, Vrlik M, Bucova M. Immunopathogenesis of bronchial asthma. Arch Immunol Ther Exp 2009; 57:331-344.

Busse WW, Lemanske RF. Asthma. N Engl J Med 2001; 344(5): 350-62.

Cao R, Dong XW, Jiang JX, Yan XF, He JS, Deng YM, Li FF, Bao MJ, Xie $Y C$, Chen XP, Xie QM. M(3) muscarinic receptor antagonist bencycloquidium bromide attenuates allergic airway inflammation, hyperresponsiveness and remodeling in mice. European Journal of Pharmacology 2011;655:83-90.

Caramori G, Papi A. Oxidants and asthma. Thorax 2004;59(2):170-3.

Carmen A. Yiamouyiannis, Craig M. Schramm, Lynn Puddington, Peter Stengel, Ebrahim Baradaran-Hosseini, Walter W. Wolyniec, Herbert E. Whiteley, and Roger S. Thrall. Shifts in Lung Lymphocyte Profiles Correlate with the Sequential Development of Acute Allergic and Chronic Tolerant Stages in a Murine Asthma Model. Am J Pathol. 1999; 154(6): 1911-1921.

Carrol N, Carello S, Cooke C, James A. Airway structure and inflammatory cells in fatal attacks of asthma. Eur Respir J 1996; 9(4): 709-15.

Castro BM, Jaeger X D, Silva C M, Lima RDF, Amaral E, Menezes C, Lima P, Neves C ML, Pires RG, Gould TW, Welch I, Kushmerick C, Guatimosim C, Izquierdo I, Cammarota M, Rylett RJ, Gomez MV, Caron MG, Oppenheim RW, Prado MV, Prado VF. The Vesicular Acetylcholine Transporter is Required for Neuromuscular Development and Function. Molecular and Cellular Biology 2009;29:5238-5250.

Chetta A, Foresi A, Del Donno M, Bertorelli G, Pesci A, Olivieri D. Airways remodeling is a distinctive feature of asthma and is related to severity of disease. Chest. 1997;111(4):852-7.

Chetta A, Foresi A, Del Donno M, Consigli GF, Bertorelli G, Pesci A, Barbee RA, Olivieri D. Bronchial responsiveness to distilled water and methacholine and its relationship to inflammation and remodeling of the airways in asthma. Am J Respir Crit Care Med 1996;153(3):910-7.... 
Cho JY, Pham A, Rosenthal P, Miller M, Doherty T, Broide DH. Chronic OVA allergen challenged TNF p55/p75 receptor deficient mice have reduced airway remodeling. Int Immunopharmacol. 2011; 11(8):1038-44.

Chung KF. Airway smooth muscle cells: contributing to and regulating airway mucosal inflammation? Eur Respir J 2000;15(5):961-8.

Commins SP, Borish L, Steinke JW. Immunologic messenger molecules: cytokines, interferons, and chemokines. J Allergy Clin Immunol 2010; 125:53-72 1.

Conrad ML, Yildirim A0, Sonar SS, Kiliç A, Sudowe S, Lunow M, Teich R, Renz H, Garn H. Comparison of adjuvant and adjuvant-free murine experimental asthma models. Clinical Et Experimental Allergy 2009; 39:12461254.

Cooper PJ, Rodrigues LC, Cruz AA, et al. Asthma in Latin America: a public heath challenge and research opportunity. Allergy 2009;64:5-17.

Corren J. Cytokine inhibition in severe asthma: current knowledge and future directions. Curr Opin Pulm Med. 2011 Jan;17(1):29-33.

Coulson FR, Fryer AD. Muscarinic acetylcholine receptors and airway diseases. Pharmacol Ther. 2003;98(1):59-69.

Dalcin PT, Menegotto DM, Zanonato A, et al. Factors associated with uncontrolled asthma in Porto Alegre, Brazil. Braz Med Biol Res 2009; 42: 1097-1103.

DATASUS. Disponivel em: www.datasus.gov.br.

De Kluijver J, Schrumpf JA, Evertse CE, Sont JK, Roughley PJ, Rabe KF, Hiemstra PS, Mauad T, Sterk PJ. Bronchial matrix and inflammation respond to inhaled steroids despite ongoing allergen exposure in asthma. Clin Exp Allergy 2005;35:1361-1369. 
Desai.D,Brightling C. TNF-alpha antagonism in severe asthma? Recent Pat Inflamm Allergy Drug Discov 2010;4(3):193-200.

Di Lallo D, Di Napoli A. Information systems in neonatology and health planning. J Matern Fetal Neonatal Med. 2011;24:1:101-3.

Dorion G, E. Israël-Assayag, M. J. Beaulieu, and Y. Cormier. Effect of 1,1dimethylphenyl 1,4-piperazinium on mouse tracheal smooth muscle responsiveness. Am J Physiol Lung Cell Mol Physio 2005 288:1139-1145.

Eglen RM, Hegde SS, Watson N.. Muscarinic receptor subtypes and smooth muscle function. Pharmacol 1996;48(4):531-65.

Elshaw SR, Henderson N, Knox AJ, Watson SA, Buttle DJ, Johnson SR. Matrix metalloproteinase expression and activity in human airway smooth muscle cells. J Pharmacol. 2004;142(8):1318-24.....

Ernst P, Suissa S. Systemic effects of inhaled corticosteroids. Curr Opin Pulm Med 2012 Jan;18(1):85-9.

Fodale, Vincenzo Santamaria,Letterio B. Cholinesterase inhibitors improve survival in experimental sepsis: A new way to activate the cholinergic antiinflammatory pathway. Critical Care Med 2008;36: 622-3.

Fryer AD, Jacoby DB. Muscarinic receptors and control of airway smooth muscle. Am J Respir Crit Care Med 1998;158(5-3):154-60.

Gallowitsch-Puerta M, Tracey KJ. Immunologic role of the cholinergic antiinflammatory pathway and the nicotinic acetylcholine alpha 7 receptor. Ann N Y Acad Sci. 2005;1062:209-19.

Giebelen IAJ, Westerloo DJV, Rosa GJL, Vos AF, Poll TV. Local Stimulation of [alpha]7 Cholinergic Receptors Inhibits LPS-Induced TNF[alpha] Release in the mouse lung. SHOCK 2007b;28:700-703. 
Global strategy for asthma management and prevention, update 2011 www.ginasthma.org.

Godfrey RWA, Lorimer S, Majumdar S, Adelroth E, Johnston PW, Rogers AV, Johansson AS, Jefery PK. Airway and lung elastic fibre is not reduced in asthma nor in asthmatics following corticosteroid tretament. Eur Respir J. 1995;8:922-7.

Goldstein RS, Bruchfeld A, Yang L, Qureshi AR, Gallowitsch-Puerta M, Patel NB, Huston BJ, Chavan S, Rosas-Balinna M, Gregersen PK, Czura CJ, Sloan RP, Sama AE, Tracey KJ. Cholinergic anti-inflammatory pathway activity and High Mobility Group Box-1 (HMGB1) serum levels in patients with rheumatoid arthritis. Mol Med. 2007;13:210-215.

Goplen N, Karim MZ, Liang Q, Gorska MM, Rozario S, Guo L, et al. Combined sensitization of mice to extracts of dust mite, ragweed, and aspergillus species breaks through tolerance and establishes chronic features of asthma. J Allergy Clin Immunol 2009;123(4):925-32.

Gosens R, S. S. Roscioni, B. G. J. Dekkers et al., "Pharmacology of airway smooth muscle proliferation," European Journal of Pharmacology 2008; 585:385-397.

Greenlee KJ, Werb Z, Kheradmand F.. Matrix metalloproteinases in lung: multiple, multifarious, and multifaceted. Physiol. Rev Physiol Rev. 2007;87(1):69-98.

Guarini S, Altavilla D, Cainazzo, MM, Giuliani D, Bigiani A, Marini H, Squadrito G, Minutoli L, Bertolini A, Marini R, Adamo EB, Venuti FS, Squadrito $F$. Efferent vagal fibre stimulation blunts nuclear fator-k $\beta$ activation and protects against hypovolemic hemorrhagic shock. Circulation 2003;107:1189-94.

Gueders MM, Foidart JM, Noel A, Cataldo DD. Matrix metalloproteinases (MMPs) and tissue inhibitors of MMPs in the respiratory tract: potential 
implications in asthma and other lung diseases. Eur $J$ Pharmacol 2006;533(1-3):133-44

Gueders MM, Paulissen G, Crahay C, Quesada-Calvo F, Hacha J, Van Hove C, Tournoy K, Louis R, Foidart JM, Noël A, Cataldo DD. Mouse models of asthma: a comparison between $\mathrm{C} 57 \mathrm{BL} / 6$ and $\mathrm{BALB} / \mathrm{C}$ strains regarding bronchial responsiveness, inflammation, and cytokine production. Inflamm Res. 2009; 58(12):845-54.

Gwilt CR, Donnelly LE, Rogers DF. The non-neuronal cholinergic system in the airways: an unappreciated regulatory role in pulmonary inflammation? Pharmacol Ther 2007;115:208-222.

Hall FC, Walport MJ. Hypereosinophilic syndromes: association with vasculitis, fibrosis and autoimmunity. Clin Exp Allergy 1993;23:542-7.

Hamid Q, Tulic M. Immunobiology of asthma. Annu Rev Physiol 2009; $71: 489-507$

Hara J, Fujimura M, Myou S, Furusho S, Abo M, Oribe Y, Ohkura N, Herai Y, Sone T, Waseda Y, Yasui M, Kasahara K. Eosinophilic inflammation, remodeling of lower airway, bronchial responsiveness and cough reflex sensitivity in non-asthmatic subjects with nasal allergy. Int Arch Allergy Immunol. 2006;140(4):327-33.

Harris RR, Carter GW, Bell RL, Moore JL, Brooks DW. Clinical activity of leukotriene inhibitors. Int J Immunopharmacol 1995; 17:147-156.

Hawrylowicz CM; O'Garra A. Potential role of interleukin-10-secreting regulatory $\mathrm{T}$ cells in allergy and asthma. Nature Reviews Immunology 2005;5(4):271-83.

Hellings PW, Ceuppens JL. Mouse models of global airway allergy: What have we learned and what should we do next? Clin Exp Allergy 2004;59:9149. 
Hofer S, Eisenbach C,Lukic IK, et al: Pharmacologic cholinesterase inhibition improves survival in experimental sepsis .Crit Care Med 2008; 36:404-408.

Hogan SP, Rosenberg HF, Moqbel R, Phipps S, Foster PS, Lacy P, Kay B, et al. Eosinophils: Biological properties and role in health and disease. Clin experimental allergy 2008; 38(5): 709-750.

Homma T, Bates $\mathrm{JH}$, and Irvin CG. Airway hyperresponsiveness induced by cationic proteins in vivo: Site of action. Am J Physiol Lung Cell Mol Physiol 2005; 289:413-418.

Hoshimo M, Nakamura Y, Sim J, Isogai S. Bronchial subepithelial fibrosis and expression of matrix metalloproteinases- 9 in asthmatic airway inflammation. J Allergy Clin immunol. 1998;102: 783-8

Howard TD, Meyers DA, Bleecker ER. Mapping susceptibility genes for allergic diseases. Chest. 2003;123(3):363-8

Huston JM, Gallowitsch-Puerta M, Ochani M, Ochani K, Yuan R, RosasBallina M, Ashok M, Goldstein RS, Chavan S, Pavlov VA, Metz CN, Yang H, Czura CJ, Wang $\mathrm{H}$, Tracey KJ. Transcutaneous vagus nerve stimulation reduces serum high mobility group box 1 levels and improves survival in murine sepsis. Crit Care Med 2007;35 (12) 2862-9.

Ito $\mathrm{K}$, Chung KF, Adcock IM. Update on glucocorticoid action and resistance. J Allergy Clin Immunol 2006; 117: 522-543.

Jason H. T. Bates,1-3 Ana Cojocaru,2 Hans C. Haverkamp,2 Lisa M. Rinaldi,2 and Charles G. Irvin1. The Synergistic Interactions of Allergic Lung Inflammation and Intratracheal Cationic Protein. Am J Respir Crit Care Med 2008;177(3):261-268.

Johnston GR, Webster NR. Cytokines and the immunomodulatory function of the vagus nerve. British Journal of Anaesthesia 2009 102(4):453-462. 
Kawakmi, M.; Matsuo Y.; Yoshiura K.; Nagase T.; Yamashita N. Sequencial and quantitative analysis of a murine modelo $f$ elastase-induced emphysema. Bio. Pharm.Bull 2008;.31 (7):1434-1438.

Kawashima K, Fujii T. Expression of non-neuronal acetylcholine in lymphocytes and its contribution to the regulation of immune function. Front Biosci. 2004;1;9:2063-85.

Keatings VM, O'Connor BJ, Wright LG, Huston DP, Corrigan CJ, Barnes PJ. Late response to allergen is associated with increased concentrations of tumor necrosis factor- $\alpha$ and IL-5 in induced sputum. J Allergy Clin Immunol. 1997;99:693-698.

Kips JC, Tavenrier J, Pauwels RA. Tumor necrosis factor (TNF) causes bronchial hyperresponsiveness in rats. Am Rev Respir Dis. 1992;145:332336.

Kistemaker LE, Oenema TA, Meurs H, Gosens R. Regulation of airway inflammation and remodeling by muscarinic receptors: Perspectives on anticholinergic therapy in asthma and COPD. Life Sci. 2012 Mar 3. [Epub ahead of print]

Kumar RK, Herbert C, Foster PS. The "classical" ovalbumin challenge model of asthma in mice. Curr Drug Targets. 2008;9:485-94v

Kummer W, Lips KS, Pfeil U. The epithelial cholinergic system of the airways. Histochem Cell Biol. 2008;130(2):219-34.

Kummer W, Wiegand S, Akinci S, Wessler I, Schinkel AH, Wess J, Koepsell $\mathrm{H}$, Haberberger RV, Lips KS. Role of acetylcholine and polyspecific cation transporters in serotonin-induced bronchoconstriction in the mouse. Respiratory Research 2006;7:65.

Kuo HP, Liu S, Barnes PJ. The effect of endogenous nitric oxide on neurogenic plasma exudation in guinea-pig airways. Eur $\mathrm{J}$ Pharmacol. 1992;221(2-3):385-8. 
Lara A., Damasceno DD, Pires R, Gros R, Gomes ER, Gavioli M, Lima RF, Guimarães D, Lima P, Bueno CR Jr, Vasconcelos A, Roman-Campos D, Menezes CA, Sirvente RA, Salemi VM, Mady C, Caron MG, Ferreira AJ, Brum PC, Resende RR, Cruz JS, Gomez MV, Prado VF, de Almeida AP, Prado MA, Guatimosim S. Dysautonomia due to reduce cholinergic neurotransmission causes cardiac remodeling and heart failure. Molecular and Celular Biology 2010;30:1746-1756.

Larche M, Robinson DS, Kay AB. The role of $T$ lymphocytes in thepathogenesis of asthma. J Allergy Clin Immunol 2003;111(3):450-63.

Left. A. Pathophysiology of asthmatic bronchoconstriction..Chest 1982;82:1321.

Leick-Maldonado EA, Kay FU, Leonhardt MC, Kasahara DI, Prado CM, Fernandes FT, Martins MA, Tibério IF. Comparison of glucocorticoid and cysteinyl leukotriene receptor antagonist treatments in an experimental model of chronic airway inflammation in guinea-pigs. Clin Exp Allergy. 2004;34(1):145-52.

Lemanske RF Jr, Busse WW. Asthma: Factors underlying inception, exacerbation, and disease progression. J Allergy Clin Immunol 2006: 456-61.

Li T, Zuo X, Zhou Y, Wang Y, Zhuang H, Zhang L, Zhang H, Xiao XXiao. The vagus nerve and nicotinic receptors involve inhibition of HMGB1 release and early pro-inflammatory cytokines function in collagen-induced arthritis. $\mathrm{J}$ Clin Immunol J 2010;30(2):213-20. .

Lima Rde F, Prado VF, Prado MA, Kushmerick C. J Neurochem.. Quantal release of acetylcholine in mice with reduced levels of the vesicular acetylcholine transporter 2010;113(4):943-51.

Lin E, Calvano SE, Lowry SF. Inflammatory cytokines and cell response in surgery. Surgery 2000;127:117-6. 
Lips KS, Lührmann A, Tschernig T, Stoeger T, Alessandrini F, Grau V, Haberberger RV, Koepsell H, Pabst R, Kummer. Down-regulation of the nonneuronal acetylcholine synthesis and release machinery in acute allergic airway inflammation of rat and mouse. Life Sci 2007;80:2263-2269.

Lips KS, Volk C, Schmitt BM, Pfeil U, Arndt P, Miska D, Ermert L, Kummer $W$, Koepsell $H$ PolyspeciWc cation transporters mediate luminal release of acetylcholine from bronchial epithelium. Am J Respir Cell Mol Biol 2005; 33:79-88.

Mabley J, Gordon S, and Pacher P. Nicotine exerts an anti-inflammatory effect in a murine model of acute lung injury. Inflammation 2011;34(4) 231-7.

Maeda S, Jun JG, Kuwahara-Otani S, Tanaka K, Hayakawa T, Seki M. Nonneuronal expression of choline acetyltransferase in the rat kidney. Life Sci. 2011;12-89(11-12):408-14.

Maouche K, Polette M, Jolly T, Medjber K, Cloëz-Tayarani I, Changeux JP, Burlet H, Terryn C, Coraux C, Zahm JM, Birembaut P, Tournier JM. alpha\}7 nicotinic acetylcholine receptor regulates airway epithelium differentiation by controlling basal cell proliferation. Am J Pathol. 2009;175(5):1868-82. .

Marketos SG, Ballas CN.Bronchial asthma in the medical literature of Greek antiquity. J Asthma. 1982;19(4):263-9.

Martinez FD, Helms PJ. Types of asthma and wheezing. Eur Respir J 1998;(27):3-8.

Masoli M, Fabian D, Holt S, et al. The global burden of asthma: executive summary of the GINA Dissemination Committee Report. Allergy 2004;59:469-478.

Mauad T, Bel EH, Sterk PJ. Asthma therapy and airway remodeling. J Allergy clin Immunol 2007;(120)5:997-1009 
Mauad T, Xavier AC, Saldiva PH, Dolhnikoff M. Elastosis and fragmentation of fibers of the elastic system in fatal asthma. Am J Respir Crit Care Med. 1999;160(3):968-75.

Maus AD, Pereira EF, Karachunski PI, Horton RM, Navaneetham D, Macklin K, Cortes WS, Albuquerque EX, and Conti-Fine BM. Human and rodent bronchial epithelial cells express functional nicotinic acetylcholine receptors. Mol Pharmacol 1998; 54:779-788.

Merouane Bencherif, Patrick M. Lippiello, Rudolf Lucas, Mario B. Marrero. Alpha7 nicotinic receptors as novel therapeutic targets for inflammationbased diseases. Cell. Mol. Life Sci. 2011;68:931-949.

Metzen J, Bittinger F, Kirkpatrick CJ, Kilbinger H, Wessler I. Proliferative effect of acetylcholine on rat trachea epithelial cells in mediated by nicotinic receptors and muscarinic receptors of the M1-subtype. Life Sciences 2003;72:2075-2080.

Ministério da Saúde.Secretaria Nacional de Ações Básicas. Estatísticas de saúde e mortalidade. Brasília: Ministério da Saúde; 2005.

Mishra, N.C., J. Rir-Sima-Ah, R.J. Langley, et al. Nicotine primarily suppresses lung Th2 but not goblet cell and muscle cell responses to allergens. Journal of Immunology 2008;180:7655-7663.

Moser R, Fehr J, Bruijnzeel PL. IL-4 controls the selective endotheliumdriven transmigration of eosinophils from allergic individulas. J Immunol. $1992 ; 15 ; 149(4): 1432-8$

Nadel JA, Takeyama K. Mechanisms of hypersecretion in acute asthma, proposed cause of death, and novel therapy. Pediatr Pulmonol Suppl 1999;18:54-5.

Parks WC and Shapiro Matrix metalloproteinases in lung biology. Respir Res. $2001 ; 2(1): 10-19$. 
Pavlov VA, Ochani M, Gallowitsch-Puerta $M$ et al. Central muscarinic cholinergic regulation of the systemic inflammatory response during endotoxemia. Proc Natl Acad Sci USA 2006; 103:5219-23.

Pavlov VA, Tracey KJ. Controlling inflammation: The cholinergic antiinflammatory pathway. Control of immune Responses 2006;34:1037-1040.

Pavlov VA, Tracey KJ. The cholinergic anti-inflammatory pathway. Brain, Behavior, and Immunity 2005;19:493-499.

Phipps S, Benyahia F, Ou TT, Barkans J, Robinson DS, Kay AB. Acuteallergen-induced airway remodeling in atopic asthma. Am J Respir Cell Mol Biol 2004;31:626-632.

Postma DS, Bleecker ER, Amelung PJ, Holroyd KJ, Xu j, Panhuysen Cl, Meyers DA, Levitt RC. Genetic susceptibility to asthma bronchial hyperresponsiveness coinherited with a major gene for atopy. N Engl J Med 1995; 333:894-900.

Postma DS, Timens W. Remodeling in asthma and chronic obstructive pulmonary disease. Proc Am Thorac Soc 2006; 3:434-439

Prado CM, Leick- Maldonado EA, Yano L, Leme AS, Capelozzi VL, Martins MA and Tibério IF. Effects of nitric oxide synthases in chronic allergic airway inflammation and remodeling. Am $J$ Physiol Lung Cell Mol Biol 2006;35(4):457-65.

Prado CM, Leick- Maldonado EA, Yano L, Leme AS, Capelozzi VL, Martins MA and Tibério IF. Effects of nitric oxide synthases in chronic allergic airway inflammation and remodeling. Am $J$ Physiol Lung Cell Mol Biol 2006b;35(4):457-65

Prado CM, Leick-Maldonado EA, Kasahara DI, Capelozzi VL, Martins MA, Tibério IF. Effects of acute and chronic nitric oxide inhibition in an experimental model of chronic pulmonary allergic inflammation in guinea pigs. Am J Physiol Lung Cell Mol Physiol 2005;289(4): 677-83. 
Prado MAM, Reis RAM, Prado VF, de Mello MC, Gomez MV, de Mello FG. Regulation of acetylcholine synthesis and storage. Neurochemistry International 2002;41:291-299.

Prado VF, Martins-Silva C, Castro BM, Lima RF, Barros DM, Amaral E, Ramsey AJ, Sotnikova TD, Ramirez MR, Kim H-G, Rossato JI, Koenen J, Quan H, Cota VR, Moraes MFD, Gomez MV, Guatimosin C, Wetsel WC, Kushmerick C, Pereira GS, Gainetdinov RR, Izquierdo I, Caron MG, Prado MAM. Mice deficient for the vesicular acetylcholine transporter are myasthenic and ave dificits in object and social recognition. Neuron 51:601$612,2006 a$

Proskocil BJ, Sekhon HS Jia Y, Savchenko V, Blakely RD, Lindstrom J, Spindel ER. Acetycholine is an autocrine and paracrine hormone synthesized and secreted by airway bronchial epithelial cells. Endocrinology 2004;145:2498-2506.

Puerta MG e Pavlov VA. Neuro-immune interactions via the cholinergic antiinflammatory pathway. Life Sci 2007;80(24):2325-2329.

Racké K, Matthiesen S. The airway cholinergic system: physiology and pharmacology. Pulm Pharmacol 2004;17(4):181-198.

Ribeiro FM, Black SAG, Prado VF, Rylett RJ, Ferguson SSG, Prado MAM. The "ins" and "outs" of the high-affinity choline transporter CHT1. Journal of Neurochemistry 2006;97:1-12.

Richardson B. Nerve supply to the lungs. Am Rev Respir Dis. 1991;119:785802 .

Rio EBM, Gallo PR, Siqueira AAF. Mortalidade por asma no município de São Paulo, Brasil. Ver. Saúde Pública. 2002;36(2):146-54.

Robert F. Lemanske, Jr., MD. and William W. Busse, MD. Asthma: Clinical Expression and Molecular Mechanisms. J Allergy Clin Immunol 2010;125 (2):95-102. 
Robinson DS. The role of mast cell in asthma: induction of airway hyperresponsiveness by interaction with smooth muscle? $\mathrm{J}$ allergy clin immunol 2004;114(1):58-65.

Roffel AF, Elzinga CR, Van Amsterdam RG, De Zeeuw RA, Zaagsma J. Muscarinic M2 receptors in bovine tracheal smooth muscle: discrepancies between binding and function. Eur J Pharmacol. 1988;153:73-82.

Rogers, DF. Motor control of airway goblet cells and glands. Respiration physiology $2001 ; 125,129-144$.

Rosas-Ballina M and K. J. Tracey, "Cholinergic control of inflammation," Journal of Internal Medicine 2009;265:663-679.

Rosas-Ballina M, Richard SG, Gallowitsch-Puerta M, Yang L, Valdés-Ferrer SI, Patel NB, Chavan S, Al-Abed Y, Yang H, and Kevin J Tracey. The selective alpha7 agonist GTS-21 attenuates cytokine production in human whole blood and human monocytes activated by ligands for TLR2, TLR3, TLR4, TLR9, and RAGE. Mol med 2009; 15(7-8) 195-202.

Schleimer RP, Sterbinsky SA, Kaiser J, Bickel CA, Klunk DA, Tomioka K, Newman W, Luscinskas FW, Gimbrone MA Jr, Mclntyre BW, et al. IL-4 induces adherence of human eosinophils and basophils but not neutrophils to endothelium. Association with expression of VCAM-1. J Immunol. 1992 ;15;148(4):1086-92.

Shi, F.D., W.H. Piao, Y.P. Kuo, D.I. Campagnolo, T.L. Vollmer, and R.J. Lukas. Nicotinic attenuation of central nervous system inflammation and autoimmunity. Journal of Immunology 2009;182: 1730-1739.

Silveira CD, Araújo Fde B, Pereira LF, Corrêa Rde A. Evaluation of the treatment provided to patients with asthma by the Brazilian Unifi ed Health Care System. J Bras Pneumol 2009;35: 628-634. 
Smith N, Broadley KJ. Optimisation of the sensitization conditions for an ovalbumin challenge model of asthma. International Immunopharmacology 2007;7:183-190.

Song XM, Li JG, Wang YL, Hu ZF, Zhou Q, Du ZH, Jia, Bao-Hui. The protective effect of the cholinergic anti-inflammatory pathway against septic shock in rats. Shock 2008;30:468-472.

Souza-Machado C, Souza-Machado A, Franco R, Ponte EV, Barreto ML, Rodrigues LC, et al. Rapid reduction in hospitalisations after an intervention to manage severe asthma. Eur Respir J 2010;35(3):515-21

Starling CM, Prado CM, Leick-Maldonado EA, Lanças T, Reis FG, Aristóteles LR, Dolhnikoff M, Martins MA, Tibério IF: Inducible nitric oxide synthase inhibition attenuates lung tissue responsiveness and remodeling in a model of chronic pulmonary inflammation in guinea pigs. Respir Physiol Neurobiol 2009, 165:185.

Struckmann N, Schwering S, Wiegand S, Gschnell A, Yamada M, Kummer W, Wess $\mathrm{J}$ and Haberberger V. Role of Muscarinic Receptor Subtypes in the Constriction of Peripheral Airways: Studies on Receptor-Deficient Mice. Molecular Pharmacology 2003;64:1444-1451.

Su X, A. Matthay MA, Malik AB. Requisite role of the cholinergic alpha 7 nicotinic acetylcholine receptor pathway in suppressing gram-negative sepsis-induced acute lung inflammatory injury. The Journal of Immunology 2010; 184: 401-410.

Su X, Lee JW, Matthay ZA, Mednick G, Uchida T, Fang X, Gupta N, Matthay MA. Activation of the alpha7 nAChR reduces acid-induced acute lung injury in mice and rats. Am J Respir Cell Mol Biol. 2007;37(2):186-92.

Subbarao P, Mandhane PJ, Sears MR. Asthma: epidemiology, etiology and risk factors. CMAJ 2009;181(9):181-190 
Taylor DR, Bateman ED, Boulet LP, Boushey HA, Busse WW, Casale TB, et al. A new perspective on concepts of asthma severity and control. Eur Respir J 2008; 32:545-54.

The FO, Boeckxstaens GE, Snoek SA, et al. Activation of the cholinergic anti-inflammatory pathway ameliorates postoperative ileus in mice. Gastroenterology 2007;133:1219-1228.

Thomas PS, Yates DH, Barnes PJ. Tumor necrosis factor-a increases airway responsiveness and sputum neutrophilia in normal human subjects. Am $J$ Respir Crit Care Med. 1995;152:76-80.

Tjitske A Oenema, Saeed Kolahian, Janke E Nanninga, Daniëlle Rieks, Pieter S Hiemstra, Suzanne Zuyderduyn, Andrew J Halayko, Herman Meurs, and Reinoud Gosens. Pro-inflammatory mechanisms of muscarinic receptor stimulation in airway smooth muscle. Respir Res. 2010;11(1):130.

Tournoy KG, Hove C, Grooten J, Moerloose K, Brusselle, GG, Joos GF. Animal models of allergen-induced tolerance in asthma: are T-regulatory-1 cells (Tr-1) the solution for T-helper-2 cells (Th-2) in asthma? Clin Exp Allergy. 2006;36:8-20.

Tracey KJ. Physiology and immunology of the cholinergic anti-inflammatory pathway. J. Clin Invest 2007; 117: 289-296.

Van Maanen, M.A., M.C. Lebre, T. van der Poll, et al. Stimulation of nicotinic acetylcholine receptors attenuates collagen- induced arthritis in mice. Arthritis and Rheumatism 2009; 60:114-122.

van Westerloo, D.J., I.A. Giebelen, S. Florquin, et al. The cholinergic antiinflammatory pathway regulates the host response during septic peritonitis. The Journal of Infectious Diseases 2005;191: 2138-2148.

Varner AE, Lemanske RF Jr. The early and late response to allergen. In Busse WW, Holgate ST, Asthma and rhinitis. Blackwell Science, 2000;117285. 
Vercelli D. Discovering Susceptibility genes for asthma and allergy. Nature reviews 2008; 8(3):169-82.

Vieira RP, Claudino RC, Duarte AC, Santos AB, Perini A, Faria Neto HC, Mauad T, Martins MA, Dolhnikoff M, Carvalho CR. Aerobic exercise decreases chronic allergic lung inflammation and airway remodeling in mice. Am J Respir Crit Care Med. 2007;176(9):871-7.

Walker C, Kaegi MK, Braun P, Blaser K. Activated T cells and eosinophils in bronchoalveolar lavage from subjects with asthma correlated with disease severity. J Allergy Clin Immunol 1991;88:935-942.

Walley AJ, Cookson WO. Investigation of an interleukin-4 promoter polymorphism for associations with asthma atopy. J Med Genet 1996; 33:689...

Wang DW, Zhou RB, Yao YM. Role of cholinergic anti-inflammatory pathway in regulating host response and its pathway in regulating host response and its interventional strategy for inflammatory diseases. Chin J Traumatol 2009; 12:355-364.

Wang $\mathrm{H}$, Liao $\mathrm{H}$, Ochani M, Justiniani M, Lin X, Yang L, Al-Abed $Y$, Wang $H$, Metz C, Miller EJ, et al. Cholinergic agonists inhibit HMGB1 release and improve survival in experimental sepsis. Nat. Med. 2004;10:1216-1221.

Waseda K, Miyahara N, Kanehiro A, Ikeda G, Koga H, Fuchimoto Kurimoto E, Tanimoto Y, Kataoka M, Tanimoto M, Gelfand EW. Blocking the leukotriene B4 receptor 1 inhibits late-phase airway responses in established disease. Am J Respir Cell Mol Biol. 2011 45(4):851-7.

Weibel ER. Principles and methods for the morphometric study of the lung and other organ. Lab Invest 12:131-155, 1963.

Wenzel SE, Schwartz LB, Langmack EL, Halliday JL, Trudeau JB, Gibbs RL, Chu HW. Evidence that severe asthma can be divided pathologically into two 
inflammatory subtypes with distinct physiologic and clinical characteristics. Am J Respir Crit Care Med 1999;54(9): 825-5.

Wenzel. Mechanisms of severe asthma. Clin Exp Allergy 2003;33(12):16228.

Wessler I, Kirkpatrick CJ, Racke K. Non-neuronal acetylcholine, a locally acting molecule, widely distributed in biological systems: expression and function in human. Pharmacol Ther 1998(77): 59-79.

Williams CM, Rahman S, Hubeau C, Ma HL Cytokine pathways in allergic disease. . Toxicol Pathol. 2012;40(2):205-15.

Woodfolk JA. Cytokines as a therapeutic target for allergic diseases: a complex picture. Curr Pharm 2006; 12:2349-63.

\section{www.Who.int/world health organization,2010}

Ying S, Durham SR, Corrigan CJ, Hamid Q, Kay AB. Phenotype of cells expressing mRNA for TH2-type (interleukin 2 and interferon gamma) cytokines in bronchoalveolar lavage and bronchial biopsies from atopic asthmatic and normal control subjects. Am J Respir Cell Mol Biol 1995;271:199-201.

Yoshikawa H, Kurokawa M, Ozaki N, Nara K, Atou K, Takada E, Kamochi H, Suzuki N. Nicotine inhibits the production of proinflammatory mediators in human monocytes by suppression of I-kappaB phosphorylation and nuclear factor-kappaB transcriptional activity through nicotinic acetylcholine receptor alpha7. Clin. Exp. Immunol. 2006;146:116-123.

Zhu W, Gilmour Ml. Comparison of allergic lung disease in three mouse strains after systemic or mucosal sensitization with ovalbumin antigen. Immunogenetics. 2009;61(3):199-207. 
Zuany-Amorim C, Haile S, Leduc D, Dumarey C, Huerre M, Vargaftig BB, et al. Interleukin-10 inhibits antigen-induced cellular recruitment into the airways of sensitized mice. J Clin Invest. 1995;95:2644-2651. 